\title{
Reproductive and Sexual Rights of Dalit Women in Chengalpattu, Tamil Nadu, India
}

\author{
by
}

Semchuddar Ponnambalam, B.A. (Honours)

\begin{abstract}
A thesis submitted to the Faculty of Graduate Studies and Research in partial fulfillment of the requirements for the degree of
\end{abstract}

\author{
Master of Arts \\ Department of Law \\ Carleton University \\ Ottawa, Ontario \\ May 12, 2006
}

(C) 2006, Semchuddar Ponnambalam 


$\begin{array}{ll}\begin{array}{l}\text { Library and } \\ \text { Archives Canada }\end{array} & \begin{array}{l}\text { Bibliothèque et } \\ \text { Archives Canada }\end{array} \\ \begin{array}{l}\text { Published Heritage } \\ \text { Branch }\end{array} & \begin{array}{l}\text { Direction du } \\ \text { Patrimoine de l'édition }\end{array} \\ \begin{array}{l}\text { 395 Wellington Street } \\ \text { Ottawa ON K1A ON4 }\end{array} & \begin{array}{l}\text { 395, rue Wellington } \\ \text { Ottawa ON K1A ON4 } \\ \text { Canada }\end{array}\end{array}$

Your file Votre référence ISBN: 978-0-494-16438-9 Our file Notre référence ISBN: 978-0-494-16438-9

NOTICE:

The author has granted a nonexclusive license allowing Library and Archives Canada to reproduce, publish, archive, preserve, conserve, communicate to the public by telecommunication or on the Internet, loan, distribute and sell theses worldwide, for commercial or noncommercial purposes, in microform, paper, electronic and/or any other formats.

The author retains copyright ownership and moral rights in this thesis. Neither the thesis nor substantial extracts from it may be printed or otherwise reproduced without the author's permission.
AVIS:

L'auteur a accordé une licence non exclusive permettant à la Bibliothèque et Archives Canada de reproduire, publier, archiver, sauvegarder, conserver, transmettre au public par télécommunication ou par l'Internet, prêter, distribuer et vendre des thèses partout dans le monde, à des fins commerciales ou autres, sur support microforme, papier, électronique et/ou autres formats.

L'auteur conserve la propriété du droit d'auteur et des droits moraux qui protège cette thèse. $\mathrm{Ni}$ la thèse ni des extraits substantiels de celle-ci ne doivent être imprimés ou autrement reproduits sans son autorisation.
In compliance with the Canadian

Privacy Act some supporting forms may have been removed from this thesis.

While these forms may be included in the document page count, their removal does not represent any loss of content from the thesis.
Conformément à la loi canadienne sur la protection de la vie privée, quelques formulaires secondaires ont été enlevés de cette thèse.

Bien que ces formulaires aient inclus dans la pagination, il n'y aura aucun contenu manquant.

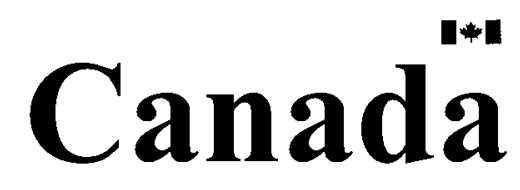




\begin{abstract}
This thesis explores the relationship between international human rights discourse, Indian National Population Policy, and women's reproductive and sexual rights in Tamil Nadu. The thesis draws from theories of third world feminism as well as critical insights from the globalization debate. Specifically it investigates the ways in which a community organization in Chengalpattu, Tamil Nadu, the Rural Women's Social and Education Center (RUWSEC), responds to the population control policies of the state of Tamil Nadu, and the Indian federal government.
\end{abstract}

It looks at RUWSEC as a case study to understand the dynamics of this relationship. This thesis argues that RUWSEC has been successful in promoting reproductive/sexual rights of Dalit women by following the principles laid out in the Beijing Platform and Cairo Programme for Action and specifically, by creating an environment where Dalit women participate directly in the design, implementation and monitoring of RUWSEC programmes. 


\section{Acknowledgments}

I dedicate this thesis in memory of my late father, Mr. Sinapoo Vallipuram Ponnambalam, who fought for the human rights of the Dalit communities in Sri Lanka. My father set an example for me to live a life where one should not judge people based on caste, creed, race or religion.

This project would not have been possible without the support of countless friends, family and colleagues within Canada and also India. While an exhaustive list is impossible, I would like to take a moment to thank a few of those individuals.

I would like to thank my thesis committee for all of your valuable feedback towards my thesis. Especially my co-supervisors, Professors Brettel Dawson and Obijiofor Aginam for providing the guidance, on going support and constructive criticism that made this thesis possible.

My family including my dear mother, Mrs. Puvanasuvary Ammal Ponnambalam who accompanied me to India to help translate during my field research. My uncle, Dr. Rasa Nathan for his ongoing support and belief in me accomplishing and achieving my academic and career goals. My cousin, Mrs. Ramani Sibi who translated and transcribed hours of field work and interview material from Tamil to English. Janet Dunkley whose unwavering support I shall never forget.

My dear friends: Sarah Leslie, Sarah Rayfield, Marcus McLean, Nama Malik and Keith Gomes for providing feedback on various chapters of this thesis.

I wish to acknowledge and extend my gratitude to the following friends and colleagues in India who made this field work a reality. These include: Rural Women's Social Education Centre Staff, the many Dalit men and women that I interviewed in Chengalpattu, Tamil Nadu. Nadigar Thilakam Sivaji Ganesan family, Mr. K. Veeraraghavan family, Kokila Amma family (especially dear Usha acca), Dr. J. Muthmary, Ph.D., and Professor K.M. Radhakrishnan.

Finally, I would like to extend my gratitude to the Legal Studies department's very own Andrew Squires for the years of exceptional professional help and friendship.

I am indebted to all of you for making my academic dream a reality. 


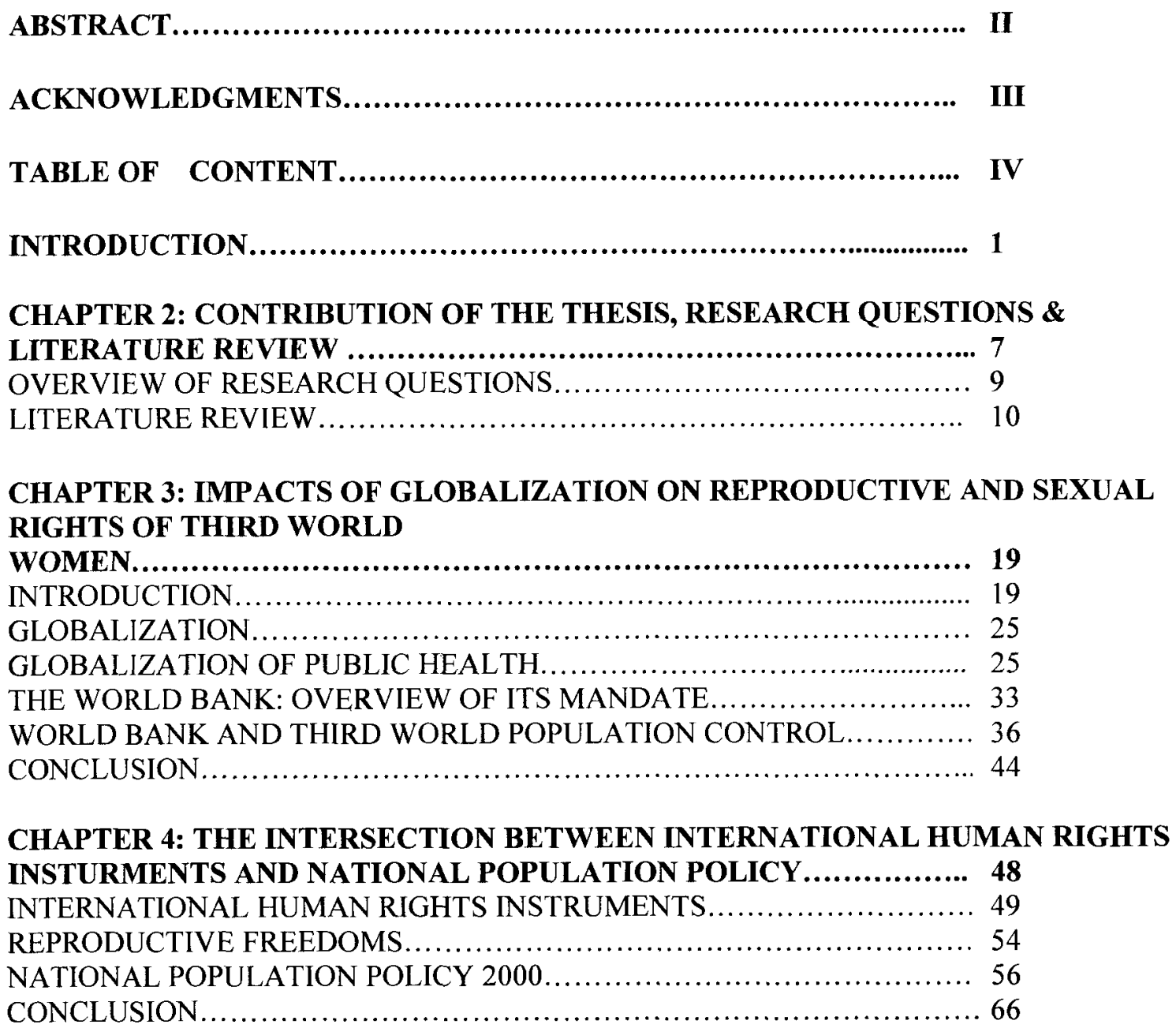

CHAPTER 5: EVALUATING GENDER EQUITY, REPRODUCTIVE AND SEXUAL RIGHTS: A CASE STUDY OF

RUWSEC................................................................... 68

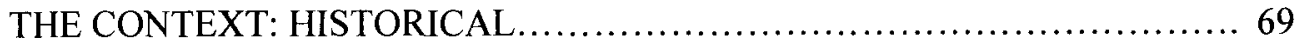

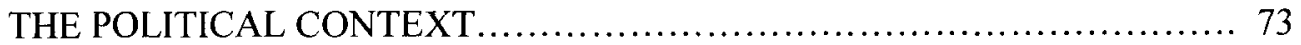

CASTE/CLASS AND COMMUNITY .......................................... 75

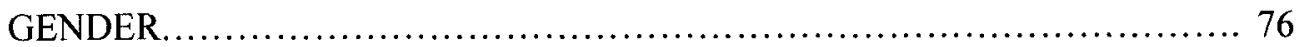

THE ORGANIZATION ................................................... 77

PROGRAMME THEMES................................................. 84

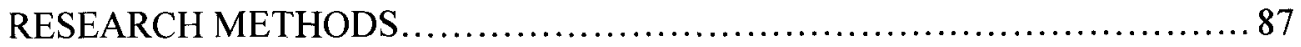

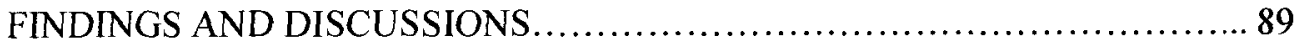

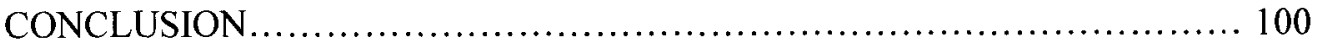

CHAPTER SIX: INTERPRETIVE ANALYSIS AND

CONCLUSION................................................................. 104 
Reproduced with permission of the copyright owner. Further reproduction prohibited without permission. 


\section{Chapter One: Introduction}

[D]alit women are thrice alienated on the basis of their class, caste ${ }^{1}$ and gender. The Dalit women have to grapple with discrimination due to caste hierarchy and untouchability on the one hand, and extreme deprivation and poverty on the other, as well as with political, legal and religiocultural discrimination. ${ }^{2}$

This introductory chapter explores the link between human rights, especially women's reproductive and sexual rights, and low caste women in Tamil Nadu, India. The State of Tamil Nadu possesses a rich cultural history. The Tamils belong to the Dravidian race said by historians to be the first inhabitants who established themselves in the northwestern region of India prior to the Indo-Aryan incursion. ${ }^{3}$ The Dravidians were pressured to progress and settle further south by the increasing Aryan invasion. This established the region composing of the contemporary States of Tamil Nadu, Kerala, Karnataka and Andhra Pradesh, all of which today still echo rudiments of Dravidian culture. ${ }^{4}$

\footnotetext{
${ }^{1}$ Allison Elliot. Caste and The God of Small Things. Fall 1997. Emory University. 1997. http://www.english.emory.edu/Bahri/caste.html (visited 03 March 2004) The caste system in India is an important part of ancient Hindu tradition and dates back to 1200 BCE. The term caste was first used by Portuguese travelers who came to India in the 16th century. Caste comes from the Spanish and Portuguese word "casta" which means "race", "breed", or "lineage". Many Indians use the term "jati". There are 3,000 castes and 25,000 sub castes in India, each related to a specific occupation. These different castes fall under four basic varnas: Brahmins-priests; Kshatryas - warriors; Vaishyas - traders; Shudras - laborers. Caste not only dictates one's occupation, but dietary habits and interaction with members of other castes as well. Members of a high caste enjoy more wealth and opportunities while members of a low caste perform menial jobs. Outside of the caste system are the Untouchables. Untouchable jobs, such as toilet cleaning and garbage removal, require them to be in contact with bodily fluids. They are therefore considered polluted and not to be touched. The importance of purity in the body and food is found in early Sanskrit literature. Untouchables have separate entrances to homes and must drink from separate wells. They are considered to be in a permanent State of impurity. Untouchables were named "Harijans" (Children of God) by Gandhi. He tried to raise their status with symbolic gestures such as befriending and eating with Untouchables. Upward mobility is very rare in the caste system. Most people remain in one caste their entire life and marry within their caste.

${ }^{2}$ Ruth Nanorama. "Statement by women's Voice and National Federation of Dalit women." Under Agenda Item5 (b) on the Rights-Based Approach to the Empowerment of women, at the ESCAP High Level Meeting for Beijing +5 ; October 28, 1999. http://www.aworc.org/bpfa/gov/escap/wv_nfdw.html (visited on 01 January 2005)

${ }^{3}$ N. Surahamanian, The History of Tamil Nadu (Madurai, Tamil Nadu: Vaigai Achagam, 1972) at 33. ${ }^{4}$ Id.
} 
Since the inception of the Rural women's Social and Education Center (RUWSEC)'s in 1981, and its focus on the rural communities of Tamil Nadu, there has been a growth of a popular culture of rights and a sense of entitlement on the reproductive/sexual rights of women and girls. This thesis focuses on RUWSEC, a community-based organization, especially its rights-based vision of gender equality, and reproductive/sexual health for lower caste women in rural Tamil Nadu. The thesis investigates the efficacy of the reproductive/sexual right advocacy of RUWSEC.

Chapter Two examines existing literature on women's reproductive and sexual rights in the Third World. Renowned academics like Maria Miles and Gita Sen have studied family planning and reproductive rights in India in recent years. Their focus has been generally on India as a whole, rather than on particular rural communities such as Chengalpattu, Tamil Nadu. This thesis combines theoretical perspectives drawn from the work of Miles, Sen and other Third World feminists with ethnographic research in Chengalpattu. In carrying out ethnographic research, I investigated the impact of RUWSEC's advocacy on Tamil Nadu women, especially how this has empowered rural women to control their reproductive/sexual practices.

Chapter Three focuses on the theoretical framework of the thesis introducing key terms and concepts. This chapter draws from theories of Third World feminism as well as critical insights on globalization of public health. Often western feminist writings focusing on Third World women are portrayed as reflecting historical homogeneities. 
Euro-American feminist scholars theorize gender and class, while Third World feminism examines gender, class and race relations as well as imperialism. ${ }^{5}$ On the contrary, Third World feminists have begun a movement, which addresses the issues that continue to clearly oppress women, whether based on race, sex, or class or reading from imperialism. $^{6}$ Throughout the thesis, I explore concepts such as the public/private dichotomy, power dynamics and the regulation of women's bodies from a Third World perspective. I explore the following questions: why are women's bodies the main site for reproductive control with regards to family planning policies in Tamil Nadu? How has law in Tamil Nadu utilized medical knowledge of women's bodies and their medical health in order to impose these family planning policies upon rural women? The RUWSEC case study was an opportunity to employ Third World feminist theories which are central in addressing concerns over reproductive and sexual rights of rural, low class, caste women's bodies in Tamil Nadu.

Chapter Three also examines the impacts of globalization on reproductive health in India. I argue that in a divided world (North/South), the human rights to health conflicts with the development policies implemented by international financial institutions, thus negatively affecting Third World health. In this chapter, I question notions of cultural neo-imperialism especially pertaining to population control agencies and transnational intuitions controlling Third World population. This chapter illustrates how international

\footnotetext{
${ }^{5}$ Cheryl Johson-Odim, "Common Themes, Different Contexts: Third World women and Feminism," in Third World women and the Politics of Feminism. Edited by Chandra Talpade Mohanty et al. (Indiana: Indiana University Press, 1991) at 315 .

${ }^{6} I d$, at 321 .
} 
financial institutions, such as the World Bank, dictate Tamil Nadu's population policy in a variety of ways.

In Chapter Four, I analyze and critique India's National Population Policy (NPP) 2000, and I argue that it fails to address the coercive methods employed in family planning programmes aimed at the poor, and that the policy tacitly approves such procedures. The aim of the National Population Policy 2000 is to regulate (by methods of contraceptive control) the bodies of poor Indian women through law and medicine. As well, I examine various International instruments such as (the Universal Declaration of Human Rights, the International Covenant on Civil and Political Rights, the International Covenant on Economic Social and Cultural Rights, and the Convention on the Elimination of All Forms of Discrimination against women) which are aimed at protecting women's human rights. I explore how medical knowledge and legal discourse form an alliance to regulate the reproductive practices of Dalit women. By examining both law and medicine's imposition on women's reproductive functions, this thesis demonstrates that law and legalism discriminate against rural Indian women, thus enabling methods such as sterilization to be prevalent. This imposes limits on Indian women's reproductive choices.

Chapter Five focuses on the case study of RUWSEC. RUWSEC's activities cover over 1000 hamlets and have helped over 30,000 women from the lowest caste in rural Tamil Nadu, India. This chapter examines the impact of international and national women's sexual and reproductive rights discourses on the population policies of a village in 
Chengalpattu (a rural community), Tamil Nadu, India. I explore how RUWSEC has closely collaborated with particular rural communities in Tamil Nadu, India, and how it has women at the grassroots mobilized in order to implement women's and adolescent's reproductive and sexual rights through methods of community organization in response to the current family planning policies of the government of Tamil Nadu, India. I interviewed and gathered data from RUWSEC staff on why, and how they succeed in promoting reproductive rights in rural communities. I conducted a total of 25 structured and unstructured interviews with both RUWSEC staff and also local women and young girls from Chengalpattu who have undergone, or are undergoing successful training provided by RUWSEC staff. I also interviewed five RUWSEC medical practitioners (doctors, nurses, hospital workers) who deal with women's health policy initiatives. This provided me with the opportunity to assess the strengths and weaknesses of their programme, and to further investigate how they have been addressed. By visiting Tamil Nadu to conduct this research, I was able to interview both women and men who have had a positive experience on the implementation process of reproductive rights in rural Tamil Nadu under RUWSEC's reproductive training.

Chapter Six presents the conclusion of the thesis. I argue that RUWSEC succeeded in promoting reproductive/sexual rights in Chengalpattu, Tamil Nadu because the organization created an environment where marginalized women and men from neighbouring villages have the opportunity to directly participate in designing, implementing and monitoring programmes. By granting women from these communities the ability to contribute in the policy arena, these rural women became empowered by 
reproductive self determination; they could now make decisions on issues that affect their reproductive and sexual rights. 


\section{Chapter Two: Contribution of Thesis, Research Questions and Literature Review}

No discussion of the feminist international perspective is complete unless it rests on a lucid analysis of one's own national roots, of one's own inscription in the network of power and signification that make up one's culture...Feminists cannot avoid confrontation with our own national ties, our location within a specific national framework. Unless this kind of feminist analysis gets elaborated, women run the risk of waving the international flag as an empty rhetorical gesture, slipping into a fantasy world...a no (wo)man's land. Proposing an international perspective without critical scrutiny of our roles in our cultural, national contexts would be only a form of supranational, that is, ultimately, a form of planetary exile. ${ }^{7}$

This chapter focuses on the contribution(s) of this thesis to academic discourse. I highlight the relevant research questions explored in the thesis. This chapter also examines the literature that is relevant to women's reproductive and sexual rights, and family panning policies relating to developing countries. My thesis explores the dynamics of caste and class which are relevant factors that affect Third World Women's reproductive/sexual rights.

\section{Contribution of Thesis to Academic Scholarship}

My study was designed to contribute to the advancement and understanding of reproductive rights of rural women in India (and other comparable developing countries facing similar problems) in overcoming cultural barriers to realize their reproductive/sexual rights. Ideally this kind of focused case study can inform policy makers concerned with women's reproductive/sexual health.

\footnotetext{
${ }^{7}$ Rosi Braidotti, "The Exile, the Nomad and the Migrant: Reflections on International Feminism," Women's Studies International Forum 15, I (1992), at 7-8.
} 
Although I was raised in a Western society, specifically Canada, I seek to speak from a Third-World feminist perspective. I identify myself as a minority Canadian woman of colour. Having been born in a Third-World country (Sri Lanka), and having strong cultural ties with my ethnic background as a Sri Lankan-Canadian woman, are important factors that contribute to my self-identification as a Third-World feminist.

Coming as well from a privileged, upper-caste background, I am aware that my biography may have an impact on my ability to analyze issues surrounding Third World women's reproductive and sexual rights. However, I hope my background presents an opportunity to highlight the issues/factors that are important to Third World women as well as Third World feminists. I feel deeply committed to addressing issues which affect Third World women wherever they live. Equally, I am committed to advancing an impartial perspective with regards to my analysis on the reproductive and sexual rights of Dalit women in Tamil Nadu, India.

I attempt to recount the "lived" experiences of these women and the experiences acquired during my research in Chengalpattu. By addressing such issues, this thesis strives to make Third World feminist voices more conspicuous in global feminist discourses instead of being relegated to a subculture of feminism. The findings from my thesis may directly assist other women based grassroots NGOs throughout India and other developing countries facing similar issues in overcoming reproductive/sexual rights limitations. I hope this study will also be useful to international, national and local policy 
makers concerned with women's reproductive/sexual health. The thesis also sheds light on the dynamics of globalization (neo-imperialism) and its impact on population policies in developing countries.

\section{Overview of Research Questions}

This thesis explores how a local women's NGO, Rural women's Social and Education Center (RUWSEC), which has closely collaborated its efforts with particular rural communities in Tamil Nadu, India, has mobilized in order to implement women's and adolescents' reproductive and sexual rights through community organization in response to the current family planning policies of the government of Tamil Nadu, India. RUWSEC was founded in 1981 by a group of women from these rural communities and it is a "woman centered and community based organization" mainly interested in implementing responses to community needs (sexual and reproductive health, immunization, health education). I chose to examine RUWSEC because its activities cover over 100 hamlets and have helped over 30,000 women from the lowest caste in rural Tamil Nadu, India.

This thesis also addresses the following subsidiary questions:

1. What methods has RUSWEC employed in order to break the cycle of rapid population growth and poverty while respecting women's reproductive rights in rural Tamil Nadu, India? To what extent?

2. Have the governments of Tamil Nadu and India begun employing similar methods of sexual and reproductive education in other rural communities in Tamil Nadu based on the successful model formulated by RUSWEC? 
3. Have family planning policies in Tamil Nadu been confined only within castes for rural women?

4. Why are women's bodies the main site for reproductive control?

5. To what extent has RUSWEC, in their reproductive health education, engaged men to take an active role with regards to reproductive education? Should men be encouraged to take an active role with regards to reproductive education? What is the significance of such a strategy?

6. What has been the role of law and national population policy?

7. Does the current National Population Policy 2000 adhere to international instruments, in protecting and empowering women with their reproductive choices?

8. How do RUWSEC's policies and programmes comply with the policies set forth with both the International Conference on Population and Development and the Beijing Platform for Action? Why has RUWSEC been successful in implementing and promoting these policies?

\section{Literature Review}

There is a significant read of feminist scholarships pertaining to women's reproductive and sexual rights and family planning policies in relation to developing countries such as India. However these seminal books and articles remain marginalized because of their focus on the Third World.

In her article, "The Sexuality Connection in Reproductive Health," Ruth Dixon-Muller provides an important introduction to the study of sexuality and health from a gender- 
sensitive perspective. Dixon-Mueller emphasizes the interconnectedness of a comprehensive understanding of, "the relationships between sexuality, gender-based power, and reproductive health". ${ }^{8}$ She critiques the methods of research and medical intervention as they are typically carried out around the world. She argues that, because "gender power relations" understand human sexuality, service providers are not able to effectively help girls and women, and vulnerable boys and men avoid violence, disease, and/or pregnancy. The frequent failure of researchers and health care providers to incorporate an analysis of gender power relations suggests that certain relevant questions fail to be posed with regards to human sexuality. According to Dixon- Mueller, this means that certain behaviours will not be mentioned, as most people are unlikely to discuss behaviours that could potentially be seen as deviant or immoral. She argues that sexuality "need[s] to be explored within a gender (and generational) framework by taking into account the ways in which structures and ideologies of gender organize experiences differently for adolescents and adult women and men". ${ }^{10}$ Only then will limitations in sexual health care be understood and rectified. Dixon-Muller offers a framework for understanding the impact of not incorporating a gender sensitive approach when providing health care to marginalized groups. In my case study analysis on Dalit women in Tamil Nadu who are involved with the RUWSEC programme, I draw upon Dixon-Muller's concept of a gender sensitive perspective focusing on the need to recognize the role of the inter-

\footnotetext{
${ }^{8}$ Ruth Dixon-Mueller. (1993). "The Sexuality Connection in Reproductive Health." Studies in Family Planning. (vol. 24): 279.

${ }_{10}^{9}$ Id.

${ }^{10}$ Id.
} 
connectedness of gender and caste play in affecting sexuality and reproductive health decisions.

The apparent contradiction between the rise of women's (and feminist) organizing in postcolonial nations, and the persistence or re-emergence of women's cultural and sexual subordination is addressed in Darini Rajasingham's article. She argues that reproductive technologies and population policies both hinder and advance women's sexual autonomy. ${ }^{11}$ On the one hand, reproductive technologies enlarge women's choices. However, paradoxically, they give impersonal forces greater access to and control over women's bodies. In the context of nationalism and the organization of postcolonial States, women's sexuality has become increasingly scrutinized, while simultaneously women's citizenship remains insecure. ${ }^{12}$ The fragile economic and political situation of many newly- independent nations has often resulted in greater regulation of women's sexuality, in order to protect the culture and nation. She cites, as one example, the initial refusal of the Indian government to sign the Convention on the Elimination of All Forms of Discrimination Against women. In this case, the Indian government claimed that the Constitutional guarantees of personal law to minority communities conflicts with several articles of the Convention. ${ }^{13}$ However, instead of leading to a call for taking apart such constitutional guarantees, Rajasingham advocates for reform toward greater gender equality within such minority communities. This article clearly illustrates why the central

11 Darini Rajasingham, 1995. "On Mediating Multiple Identities: The Shifting Field of women's Sexualities within the Community, State and Nation," in Margaret A. Schuler, ed., From Basic Needs to Basic Rights: women's Claim to Human Rights. Washington, DC: women, Law and Development International: 235.

${ }^{12}$ Id. 237.

${ }^{13} \mathrm{Id}$. 
government of India's population policy is in fact limiting women's reproductive/sexual rights.

Through the use of policy analysis and case studies, Bonnie Shepard in her article, "The 'Double Discourse' on Sexual and Reproductive Rights in Latin America: The Chasm between Public Policy and Private Actions," examines the "double discourse" system and sheds light on how contradictory perspectives on reproduction and sexuality are instituted and maintained. She reveals how repressive or negligent public policies exist on top of privately tolerated, unofficial, and often illegal mechanisms that actually expand the sexual and reproductive choices of individuals. Shepard investigates the gap between policy rhetoric and people's everyday reality by looking at the specific cases of divorce law in Chile and abortion advocacy in Colombia and Chile. This double discourse functions as an escape valve to "allow private accommodations to repressive policies, leaving the official legal and/or religious norms untouched while reducing the social and political pressure for policy advances"14. The double discourse also functions as the cultural and political articulation of systemic contradictions: it both supports and recreates existing power relations, so that its benefits are more readily available to more politically and economically powerful individuals. ${ }^{15}$ One result is that those who are already disadvantaged or discriminated against do not reap the benefits of this system nor do they have the power to change it. Shepard also examines the backlash that frequently

\footnotetext{
${ }^{14}$ Shepard Bonnie (2000). "The 'Double Discourse' on Sexual and Reproductive Rights in Latin America: The Chasm between Public Policy and Private Actions." Health and Human Rights. (vol. 4. no. 2): 113. ${ }^{15} \mathrm{Id}$.
} 
erupts when people try to break the double discourse system by speaking out about the "escape valves." $"$ All too often, direct contestation results in repression.

The article, "Sexual Pleasure as a Woman's Human Right: Experiences from a Grassroots Training Programme in the Human Rights Advocacy Turkey" is based on Ipek Ilkkaracan's and Gülsah Seral's own human rights advocacy work with women for women's Human Rights (WWHR), an NGO in Turkey. They examine the way that WWHR weaves issues of women's sexuality into human rights training. The authors argue that by first emphasizing a range of human rights issues, and later the human rights aspects of sexuality, participants in the training are less intimidated by discussions about sexuality. Ilkkaracan and Seral show how the WWHR programme effectively uses separate modules to discuss a wide range of human rights issues, thereby giving equal emphasis to and separating the issues of violence, reproductive rights, and pleasure. The authors outline the structure of the sexuality module, and indicate how the different steps work to "establish incrementally an empowering definition of sexual rights". ${ }^{17}$ These steps include a group discussion of social myths, small group discussions of personal experiences of sexuality, an information session, and a concluding discussion that focuses specifically on sexual rights. Ilkkaracan and Seral argue that, through a sensitively designed training, women can not only learn more about sexual rights, but can also be encouraged to explore their own sexuality. ${ }^{18}$ Their article advances an understanding of

\footnotetext{
${ }^{16} I d$. at 141.

17 Ipek Ilkkaracan and Gülsah Seral, 2000. "Sexual Pleasure as a Woman's Human Right: Experiences from a Grassroots Training Programme in Turkey." in Pinar Ilkkaracan, ed., Women and Sexuality in Muslim Societies. Istanbul: Women for Women's Human Rights, at 192.

${ }^{18}$ Id. 197.
} 
the policies implemented by RUSWEC. RUWSEC makes use of similar empowerment techniques such as small group discussions of sexual experiences, information sessions, discussions about gender roles and power associated with such roles.

Along the same lines, the article entitled, "Reproductive and Sexual Rights: A Feminist Perspective," by authors Sonia Correa and Rosalind Petchesky, defines the terrain of reproductive and sexual rights in terms of power and resources, involving a core notion of "bodily integrity" or "control over one's body." "I In doing so, this essay has had a significant influence on developing concepts of "sexual rights," particularly in the context of global women's health and rights advocacy. The authors recommend a reconstruction of the rights discourse that specifies gender, class, cultural and other differences, while recognizing social needs or enabling conditions. While they explore the theoretical and historical foundations of "reproductive" and "sexual" rights, their emphasis is on policy implications of reproductive and sexual rights concepts and advocacy. ${ }^{20}$ They are especially concerned with how to bridge the "individual-social" divide. To address this, they offer a set of ethical principles for reproductive and sexual rights: bodily integrity, personhood, equality, and diversity. This leads them to propose that governments and population agencies must do more than avoid abuses. Rather, what is required is a reordering of priorities, including affirmative programmes to advance gender equality, promote women's empowerment, and redistribute resources in a fashion that promotes

\footnotetext{
19 Sônia Correa and Rosalind P. Petchesky, 1994. "Reproductive and Sexual Rights: A Feminist Perspective." in Gita Sen, Adrienne Germain, and Lincoln C. Chen, eds., Population Policies Reconsidered: Health, Empowerment, and Rights. Boston: Harvard Center for Population and Development Studies; and New York: International women's Health Coalition, at 108.

${ }^{20} \mathrm{I} d .110$.
} 
liberty and social justice. ${ }^{21}$ This article clearly exhibits the relationship between Indian women's reproductive/sexual rights and government population policies.

The essay, "On Women's Right to Experience their Sexuality Free from Illness," by Ana Maria Costa, links feminist studies of bioethics to issues of women's sexuality. Costa notes that acknowledging differences between and among women and men is critical to understanding and responding to women's health needs, particularly in terms of sexual health. All too often, health interventions result in the medicalization of women's bodies, and a dismissal of the impact of a range of differences (race, class, and ethnicity) on women's health and sexuality. ${ }^{22}$ In contrast, Costa proposes that a clearer understanding of different approaches can result in the practice of medicine as an instrument allied with women's empowerment and the realization of women's sexual rights. ${ }^{23}$ I use this article to strengthen my theoretical perspectives on medicalization of women's bodies.

Lastly, Rebecca Cook's, "Human Rights and Reproductive Self-Determination," presents an overview of the application of human rights norms and standards to reproductive and sexual health and sexuality. ${ }^{24}$ Arguing that the linkages between reproductive health and human rights are varied and complex, Cook offers a broad framework for advancing human rights protections for reproductive self-determination. ${ }^{25}$ She examines how legal strategies and population policies have tended to ignore women's own perceptions of

${ }^{21}$ Id. 123.

22 Maria Ana Costa, 2000. "On Women's Right to Experience their Sexuality Free from Illness." Women's Health Collection/5: women, Sexualities, Rights. Santiago, Chile: Latin American and Caribbean Women's Health Network.

${ }^{23}$ Id.

24 Rebecca J Cook., (1995). "Human Rights and Reproductive Self-Determination." The American University Law Review. (vol. 44. no. 4): 980.

${ }^{25}$ Id. 1010 . 
their needs. Cook then provides a detailed analysis of the application of human rights to reproductive self-determination, including rights relating to sexuality. She presents four categories of rights: rights relating to reproductive security and sexuality; rights relating to reproductive health; rights relating to reproductive equality; and rights relating to reproductive decision-making. ${ }^{26}$ At the same time, she also discusses how these rights are, more often than not, violated. Cook provides an analysis of State accountability, noting how governments can be encouraged to fulfill their obligations to make reproductive self-determination a reality. This article lays the groundwork for my thesis. I draw on Cook's four categories of rights when examining the reproductive and sexual rights of Dalit women, girls and men in Tamil Nadu, India. Her ideas are particularly relevant for understanding the need to incorporate sexual and reproductive rights in international instruments so that these instruments can be adopted by national and State governments with pressure from feminist NGOs.

Renowned academics like Maria Miles and Gita Sen, among others have studied family planning and reproductive rights in India in recent years. Their focus has been generally on India as a whole, rather than on particular rural communities such as Chengalpattu, Tamil Nadu. This thesis combines theoretical perspectives drawn from the work of Miles, Sen and other Third World feminists with the ethnographic research conducted in Chengalpattu. In summation, I have come to realize that in order to gain a holistic account of women's reproductive and sexual rights in Chengalpattu India; I must utilize academic works from both western and developing countries. However, I predominately utilize theory which focuses on Third World women and population policies because they ${ }^{26}$ Id. 976 . 
take into account, gender, race, class. Unlike the literature presented earlier, my thesis takes into account the dynamics of caste and class which are relevant factors that affect Third World women's reproductive/sexual rights. In addition, I look at the role of civil society in the struggle for reproductive and sexual rights advocacy in the Third World. This thesis demonstrates that a holistic approach should be in place when promoting reproductive and sexual health services which are directly in line with the International Conference on Population Development Programme of Action. My thesis looks at where governments leave a gap in governance, civil society groups can fill the gap, with funding and capacity.

This chapter focused on the contribution of this thesis to academic and policy discourses, the major and subsidiary research questions as well as literature review on reproductive and sexual rights and population policies. The next chapter examines how factors such as globalization along with transnational actors such as the World Bank negatively impact the reproductive and sexual rights of Third World women. The following chapter questions notions of cultural neo-imperialism using both Third World feminist theories and globalization of health perspectives pertaining to population control agencies. 


\section{Chapter Three \\ Impacts of Globalization on Reproductive and Sexual Rights of Third World women}

The impact of globalization is to take resources that have been under women's control, and the control of Third World communities to generate substance and survival, and put them at the service of global trade and commerce to generate profits. ${ }^{27}$

\section{Introduction}

This chapter employs Third World ${ }^{28}$ feminist $^{29}$ theory to examine how globalization has come to have a negative impact on the reproductive and sexual rights of Third World women. First, I address the effects of globalization ${ }^{30}$ on Third World women's health,

\footnotetext{
${ }^{27}$ Vandana Shiva. (Spring 1997) "Economic Globalization, Ecological Feminism, and Sustainable Development." Canadian Woman Studies. (vol. 17. no.2): 22.

28 "The poorest nations of the world. Most Third World nations are in debt to Western banks and governments or international lending organizations. Many depend on international aid to meet the basic needs of their population. This term has fallen into disfavour in recent years, replaced by terms such as Less-Developed Country (LDC), developing nations, and the Global South." The University of Maryland. Research Library: Glossary of Scenario Terms. http://www.icons.umd.edu/reslib/display glossary\#T (visited: 02/20/2006)

${ }^{29}$ Chandra Talpade Mohanty defines the term "Third World women "are geographically from: "the nationStates of Latin America, the Caribbean, Sub-Saharan Africa, South and South-east Asia, China, South Africa, and Oceania constitute the parameters of the non-European Third World. In addition, black, Latino, Asian, and indigenous peoples in the U.S., Europe, Australia, some of whom have historic links with the geographically defined Third Worlds, also define themselves as Third World peoples" (5).

Mohanty uses the term interchangeably with "women of colour" (7). She argues that "what seems to constitute 'women of colour' or 'Third World women' as a viable oppositional alliance is a common context of struggle rather than colour or racial identifications. Similarly, it is Third World women's oppositional political relation to sexist, racist, and imperialistic structures that constitutes our political commonality" (7). Although she uses the term "Third World women," Mohanty argues that western feminisms appropriate the production of the "Third World woman as a singular monolithic subject," for a "discursive colonization" (51). Furthermore, western feminisms articulate a discursive colonization through the production of "Third World difference": "that stable, ahistorical something that apparently oppresses most if not all of the women in [Third World] countries" (53-54). Western feminisms' use of the category of Third World woman and Third World difference ties into a larger, latent cultural and economic colonialism: "in the context of the hegemony of the Western scholarly establishment in the production and dissemination of texts, and the context of the legitimating imperative of humanistic and scientific discourse, the definition of the 'Third World woman' as a monolith might well tie into the larger cultural and economic praxis of 'disinterested' scientific inquiry and pluralism which are the surface manifestations of a latent economic and cultural colonization of the 'non-Western' world" (74).

Chandra Talpade Mohanty. "Introduction" and "Under Western Eyes." Third World women and the Politics of Feminism. Eds. Mohanty, Russo, Torres. Bloomington and Indianapolis: Indiana UP, 1991.

${ }^{30}$ The perspective of contemporary globalization theorists like Held and McGrew define globalization as: "It is characterized by four types of change. First, it involves a stretching of social, political and economic activities across frontiers, regions and continents. Second, it is
} 
and second the influence of the World Bank (WB) reproductive policies in developing countries. The thesis explores the relevance of the nation-State to the dynamics of globalization and how these dynamics influence the health of Third World women. It also examines how international financial institutions, such as the World Bank, have influenced population policies in the Third World. I argue that under the dynamics of globalization, Third World countries, such as India, have limited powers in promoting and protecting the reproductive and sexual rights of local women.

Globalization impacts women, especially those from developing countries, in numerous ways. As Shiva argued, these women as those, "who feed the world, tend nature and their families and who are in particular suffering from the new health and ecological hazards due to the impact of globalization on the poor."31 These women make up $90 \%$ of the 27 million Free Trade Zones (Third World countries). These women work three or four hours longer than their husbands in the home, field and factories and in uncounted numbers in the informal sector. ${ }^{32}$

marked by the intensification, or the growing magnitude, of interconnectedness and flows of trade, investment, finance, migration, culture, etc. Third, it can be linked to a speeding up of global interactions and processes, as the development of world-wide systems of transport and communication increases the velocity of the diffusion of ideas, goods, information, capital and people. And, fourth, the growing extensity, intensity and velocity of global interactions can be associated with their deepening impact such that the effects of distant events can be highly significant elsewhere and specific local developments can come to have considerable global consequences. In this sense, the boundaries between domestic matters and global affairs become increasingly fluid. Globalization, in short, can be thought of as the widening, intensifying, speeding up, and growing impact of world-wide interconnectedness." David Held and Anthony McGrew. Globalization: Entry from Oxford Companion to Politics. Globalization in Global Transformations. http://www.polity.co.uk/global/globocp.htm (visited: 02/20/2006) Please see this chapter for further information on globalization.

${ }^{31}$ Wendy Harcourt, quoting Shiva in her article, "Women, Health and Globalization." Draft for discussion 15 June 2000. (visited: 02/20/2005) Retrieved from www.sidint.org/Publications/ Docs/SID-2000-AnnualReport.pdf ${ }^{32}$ Id. 
In order to analyze Third World feminist theory we need to define Third World women.

These women have often been defined in past/contemporary societies by some western feminist scholars as being subjected to underdeveloped/oppressive traditions, high illiteracy, rural and urban poverty, religious fanaticism, and "overpopulation" particularly in Asian, African, Middle Eastern and Latin American countries. ${ }^{33}$

For although the oppression of women is universal in nature...it is time to move beyond simple truism about the situation of women to a more profound analysis of the mechanisms perpetuating the subordination of women in society...In the Third World, women's demands have been explicitly political, with work, education and health as major issues per se and not so linked to their specific impact on women. In addition, women of the Third World perceive imperialism as the main enemy on their continents and especially of women... ${ }^{34}$

In such circumstances, Western feminist analysis often focus on the coherent group (Third World women) as having identical interests and desires, regardless of class, ethnic, or racial location, or contradictions, instead this leads to the implication of a notion of gender or sexual difference or even patriarchy that can be applied universally and cross culturally. ${ }^{35}$ This lack of distinction is derived from the "privileged" nature of a particular group (Western feminism) as being the norm. It is true that for Third World women their struggle mainly focuses on their communities and their fight against infant mortality, problems concerning nutrition, illiteracy, adequate health care, skill training, economic

\footnotetext{
${ }^{33}$ Chandra Talpade Mohanty, "Cartographies of Struggle: Third World women and the Politics of Feminism, in Third World women and the Politics of Feminism. Edited by Chandra Talpade Mohanty et al. (Indiana: Indiana University Press, 1991), at 5-6.

${ }^{34}$ Marie Angelique Savan.(1982). "Another Development with women.” Development Dialogue (vol. 1. no. 2): 5 .

${ }^{35}$ Chandra Talpade Mohanty, "Under Western Eyes: Feminist Scholarship and Colonial Discourses," in , Feminism Without Borders: Decolonizing Theory, Practicing Solidarity (Duke University Press: Durham \& London 2003) at 21.
} 
exploitation, and especially racism. However, this assumes that all Third World women are a coherent/homogenous group where they have identical interests and moreover this argument does not take into account their respective class, ethnic or racial location, and caste of these women.

Do these women have similar constituencies and are their struggles founded on the same basis? Whose history defines the struggle for Third World feminism and how do gender, race and nation intersect in determining feminism in the Third World? In contemporary feminist theory, "women" as a category is employed by some Western feminist discourse to portray Third World women as being homogeneous, powerless group often victims of a particular socioeconomic system. ${ }^{36}$ For instance, Fran Hosken, in her work dealing with human rights and female genital mutilation in Africa and the Middle East, focused her entire discussion on condemning genital mutilation because it "mutilates the sexual pleasure and satisfaction of woman." 37 Many African feminists argue that Western feminists mainly focus on female genital mutilation thus sensationalizing this one topic and are disconnected with the broader struggle. For example Western feminists portray the "African woman as being a cultural indigenous phenomenon."

Rather than seeing men as the universal oppressor, women will also be seen as partners in oppression and as having the potential of becoming primary oppressors themselves. Above all, by studying the Black woman we can avoid isolating sexism from the larger political and economic forces operating in many societies to produce internal colonialism and economic dependency-all of which affect both men and women in Africa,

\footnotetext{
${ }^{36} I d ., 23$.

${ }^{37}$ Fran Hosken, (Summer 1981). "Female Genital Mutilation and Human Rights." Feminist Issues. (vol. I. no. 3): 15 .
} 
the Caribbean, South America and impoverished sections of the United States. $^{38}$

Colonization is often defined as the subjugation of another's culture. The seven aspects of colonization being the geographical incursion; destruction of social, spiritual and cultural systems and relations; external political control; economic dependence; lower quality health and social services; social interaction based on racism; and the establishment of the colour-line. ${ }^{39}$

Ann Seidman suggests that "according to Marxist theory, colonization has been termed as a category of exploitive economic exchange and this term has been used freely by feminists of colour in the United States in order to describe the economic and political hierarchies of a particular cultural discourse about what is called the Third World."40 Third World feminists, such as Chandra Talpade Mohanty, often argue that some feminist writings, upon examination, colonize the material and historical heterogeneities of the lives of women in the Third World, thereby often reproducing images of a "singular Third World woman"-an image often arbitrarily constructed but nevertheless carry with it the authorization signature of Western humanist discourse. ${ }^{41}$

Colonization has historically had ties to the Third World. This has affected different groups of women within each State. Colonization has individually affected Indian women. During the nationalist movement, the Indian woman was deemed the "goddess",

\footnotetext{
${ }^{38}$ Ann Seidman. "Women and the Development of Underdevelopment." In R. Dauber and M. Cains, eds. Women and Technological Change in Developing Countries. (Boulder, Colorado: West view Press), 1981, at 3 .

${ }^{39}$ James O Gump. "The West and the Third World: Trade, Colonialism, Dependence and Development." Journal of World History. Fall 2000: 396-398.

${ }^{40}$ Chandra Talpade Mohanty, Feminism Without Borders: Decolonizing Theory, Practicing Solidarity (Duke University Press: Durham \& London 2003), p.18.

${ }^{41}$ Id. 19
} 
however, not all women fell into this category, if you were poor and belonged to a lowercaste community you would never be considered the "goddess." 42 During the anticolonial Indian nationalist movement, often the "Indian culture" was portrayed incorrectly. Contemporary India also distinguishes and tends to favour people from the upper castes despite the various affirmative action legislation put into place. This was a problematic assumption because these examinations often ignored to mention that India is a culturally, economically and religiously diverse nation-State.

Women of Colour have not had the benefit of the economic conditions that underlie the private/public distinction. Instead the political consciousness of women of Colour stems from awareness that the public is personally political. Welfare programmes and policies have discouraged family life, sterilization programmes have restricted reproductive rights, governments has drafted and armed disproportionate number of people of Colour to fight its wars overseas, and locally, police forces and the criminal justice system arrest and incarcerated disproportionate numbers of people of Colour. There is no such thing as a private sphere for people of Colour except that which they manage to create and protect in an otherwise hostile environment. ${ }^{43}$

The United Nations International Conference on Population and Development held in Cairo 1994 produced a "Programme of Action", which is designed to be a major tool in helping change reproductive health practices even in the wake of the negative global economic environment affecting mainly the poor (developing countries). ${ }^{44}$ Nationally and locally, Third World women's reproductive rights are among some of the important policies addressed by both feminist groups and women's non-governmental

\footnotetext{
${ }^{42}$ Partha Chatterjee. (Nov. 1989) "Essay on the Family," American Ethnologist. (vol.4) :626.

43 Aida Hurtado, quoting Vandana Shiva (Summer, 1989). in her article, "Relating to Privilege: Seduction and Rejection in the Sub-ordination of White Women and Women of Colour." Signs: Journal of Women in Culture and Society. (vol. 14): 833-855.

${ }^{44}$ Id .849
} 
organizations. As a collective they are trying to advance more equitable policies that reflect a "pro-poor" health agenda especially pertaining to women's reproduction.

\section{Globalization}

The term globalization is complex to define. In recent years there has been a great deal of interest in academia, the government, and civil society all focused on trying to understand it. The difficulty in defining globalization is succinctly captured by Obijiofor Aginam, when he States that, "globalization means different things to different people in different places and disciplines, and its scope and historical antecedents lie in the particular eyes of the beholder"45. I use David Held's definition of globalization. According to Held and McGrew, globalization is defined as:

distinctive spatio-temporal and organizational attributes..., particular patterns of extensity, intensity, velocity, and impact in global relations, flows and networks, alongside different degrees of institutionalization, modes of stratification and reproduction...unique spatio-temporal and organizational features, creating a world in which the extensive reach of global relations and networks is matched by their relative high intensity, high velocity and high impact propensity across facets of social life ${ }^{46}$.

As previously stated, globalization from the perspective of Held and McGrew, reflects "the widening, intensifying, speeding up, and growing impact of world-wide interconnectedness." 47

\footnotetext{
${ }^{45}$ Obijiofor Aginam, Global Health Governance: International Law and Public Health in a Divided World (Toronto: University of Toronto Press, 2005), at 32.

${ }^{46}$ David Held and A. McGrew, "Introduction" in David Held and A. McGrew in eds., Governing Globalization; Power, Authority and Global Governance. (Cambridge, Polity Press, 2002) at 2.

${ }^{47}$ See footnote 30 , Page 19.
} 
The erosion of the nation-State's governance structures, which are patriarchal in nature, corresponds to a transfer of these power structures from the nation-State to transnational actors and subsequently intensifies patriarchal power. Iris Young argues that the nation State has always been patriarchal, meaning that the citizens are expected to play a role analogous to submissive wives to strong husbands ${ }^{48}$. Amina Mama suggests that:

[C]onceptualization, although based on good materialist analysis, does not fully sabotage or challenge the gender assumptions of malestream political economy.... The discourses that continue to position women-as-mothersand-wives also uphold a particular moral order, one which has constrained the sexual choices and preferences of women legal, policy and service provisions challenged a social and economic order that depends on continuing to position women's interests as subordinate to the economic, cultural and psychosexual satisfactions of men $?^{49}$

According to Christine Chinkin, "power has been fragmented through the emergence of new social formations demanding loyalties from members of the group and presenting their claims internationally through their collectives, often to the detriment of individuals, most notably women"50. The dynamics of globalization affect women differently.

Amina Mama states that:

In addition, neoliberal economic paradigms see international funding threaten to reconfigure many women's groups into service-providers; increasingly, women are being conscripted as foot soldiers of social adjustment, forced to labour unwaged to plug the holes left in the social fabric by the externally imposed retraction and subsequent collapse of public services. This tendency of social adjustment to absorb women's work and energy threatens to mitigate against the emerging militancy of mobilization of women that seek to call governments back from the ruthless clutches of international financial agencies, to account to those that elected them. ${ }^{51}$

\footnotetext{
${ }^{48}$ Iris Young. (2003). "Feminist Reactions to the Contemporary Security Regime", Hypatia. (vol. 18.no. 1): 223

49 Amina Mama, "Editorial," Feminist Africa: Issue 4: 2005. http:/www. feministafrica.org/042005/editorial.html (visited: 02/22/2006)

${ }^{50}$ Christine Chinkin, "Gender and Globalization", United Nations Chronicle Online Edition, volume XXXVII, No. 2 2000, Dept. of Public Information http://www.un.org/Pubs/chronicle/2000/issue2/0200p69.htm

${ }^{51}$ Amina Mama, "Editorial," Feminist Africa: Issue 4: 2005. http://www. feministafrica.org/042005/editorial.html (visited: 02/22/2006)
} 
In some circumstances, globalization has created employment opportunities for women, specifically from the Global North, where those opportunities did not exist before ${ }^{52}$. Due to economic independence that accompanied this employment, some of these women have been able to assert their own agency ${ }^{53}$. Globalization's effects depend on the interaction of numerous factors such as gender, class, age, education level, race and ethnicity. Chandra Talpade Mohanty argues that:

[b]lack, white, and other Third World women have very different histories with respect to the particular inheritance of post-fifteenth-century EuroAmerican hegemony: the inheritance of slavery enforced migration, plantation and indentured labor, colonialism, imperial conquest, and genocide. Thus Third World feminists have argued for the rewriting of history based on the specific locations and histories of struggle of people of colour and postcolonial peoples, and on the day-to-day strategies of survival utilized by such peoples. ${ }^{54}$

Globalization is mainly detrimental to those Third World women who were historically subjected to colonial practices. Similarly, Oloka-Onyango and Tamale argue that in order to comprehend the Third World dimension on the effects of globalization, one needs to focus on the slogan "the local is global." ${ }^{55}$ The local circumstances and conditions of patriarchy and exploitation in the Third World are a result of the intricately connected nature of today's international conditions. ${ }^{56}$ Unlike their western counterparts, women from the South confront the State and other transnational actors through the medium of a

\footnotetext{
${ }^{52} I d$

${ }^{53} I d$.

${ }^{54}$ Chandra Talpade Mohanty, "Cartographies of Struggle, Third World Women and the Politics of Feminism," in Third World Women and the Politics of Feminism .Chandra Talpade Mohanty et al. eds. (Bloomington and Indianapolis: Indiana UP, 1991), at 10.

${ }^{55}$ J. Oloka-Onyango and Sylvia Tamale. (1995). "The Personal is Political, or Why Women's Rights are Indeed Human Rights: An African Perspective on International Feminism" in Human Rights Quarterly (vol. 17.no. 4): 701.

${ }^{56}$ Id. at 702 .
} 
global network based upon imperialist relations. ${ }^{57}$ Consequently these women have less power to contest the on going changes that directly affect their health. This is due to their disadvantaged position within the State; and also, because the State itself is subjected to neo-liberalist policies initiated by external forces such as the World Bank. This is an example of how globalization negatively affects Third World women. Focusing on issues that impact globalization in the African context, Mahmood Mamdami argues that:

In sharp contrast to the residents of the global village is the mass of the peasantry, whose cultural horizons are narrowing rather than expanding. They are encouraged to return to narrow ethnic or religious preoccupations. The new global order has a new answer to the age-old problem of how to control the colonized. That answer, in a world, is "decentralization" without democratization it is evident that the answer of decentralization, however, is not the new. During colonialism it was called "indirect rule." 58

In such economic cases in an attempt to reach marginal stabilization social programmeshealth, housing, education are cut throughout the Third World. This appears to have negative implication towards developing people specifically women who are greatly impacted. In such circumstances, Michel Chossudovsky suggests that in order to pay back debt to International Financial Institutions, developing countries often cut their social programmes. Chossudovsky further states that this is "economic genocide" by which he means "a conscious and deliberate manipulation of market forces by global institutions"-World Bank, IMF, and WTO.,59

It is not surprising that neo-liberalist ideology emerged throughout Third World States. Under this climate Third World women are further marginalized. The State no longer

${ }^{57}$ Id.

${ }^{58}$ Mamdani, Mahmood. 1995. "The Politics of Democratic Reform in Contemporary Uganda." East African Journal of Peace and Human Rights (vol. 2 no .1): 94.

${ }^{59}$ Michel Chossudovsky, The Globalization of Poverty: Impacts of IMF and World Bank Reforms

(London: Zed Books, 1997) 33 
supports programmes which are promoting safer reproductive health practices for poor women.

\section{Globalization of Public Health}

With the upsurge of global interdependence networks, the objectives of national foreign policies pertaining to health are undergoing dramatic changes. According to David Woodward:

globalization is a key challenge to public health, especially in developing countries, but the linkages between globalization and health are complex.... where economic benefits of globalization need to be translated into health benefits... This requires that economic growth be sustainable and consciously directed towards the poor, through better design of propoor national economic policies...equally where globalization has adverse economic effects on a country, the impact on health must be minimized. This means protecting health-related spending from reductions in public expenditure, limiting the adverse effects of low or negative growth on the incomes of the poor, and increasing aid and improving policy design to achieve these objectives. ${ }^{60}$

For instance, the control and surveillance of communicable diseases has become a matter of preventive diplomacy. ${ }^{61}$ Former World Health Organization Director-General, Hiroshi Nakajima notes:

Foreign policies based on narrow interests of isolationism and protectionism will reduce the creative spirit of international scientific investigation... The global [health] development strategies needed to address these complex and inter-related problems will require innovative, intersectoral interventions, involving a high degree of international cooperation and political will. ${ }^{62}$

\footnotetext{
${ }^{60}$ David Woodward et al. Globalization and Health: a Framework for Analysis and Action. Bulleting World Health Organization [online]. 2001.( vol. 79. no.9) :875-881.

61 Derek Yach, and Douglas Bettcher,. (May, 1998). "The Globalization of Public Health, I: Threats and Opportunities." American Journal of Public Health. (vol. 88.no. 5):735-737

${ }^{62}$ Hiroshi Nakajima. (1997).“Global Health Threats and Foreign Policy." Brown Journal World Affairs. (vol. 4) :320.
} 
There is a growing debate about whether globalization promotes positive health policies in developing countries. For instance, with modern information technologies becoming more accessible and affordable to developing countries, the potential benefits could be extensive: "thus uses of modern information technology in health include telemedicine, interactive health networks, communication services between health workers, human resource development and continuing education, and distance learning." ${ }^{\text {"63 }}$ However, in order to "provide these facilities in the poorest communities of the world this may require special government incentive, including incentives that could be at odds with norms governing liberalization of trade and removal of special subsidies." ${ }^{64}$ With the removal of special subsidies, the poor predominately being women become further marginalized under such conditions. Fidler notes that "the internationalization of public health did not, however, achieve the objectives of improving health capabilities in much of the developing world." 65 Allyn L. Taylor further argues that "[s]ince WHO initiated the Health for All strategy [1997], disparities in health standards between rich and poor nations have increased and health spending in most developing nations has declined."66 Due to reduced funding and pressures from external agencies such as the World Bank, health policies, pertaining to 'family planning' or population control seem to be limiting local women from exercising their reproductive and sexual rights.

As public health is tied to development, the phenomenon of globalization has conspired with poverty to wreak havoc on the health of populations in the developing world. The world is witnessing the "globalization of

\footnotetext{
${ }^{63}$ Health Informatics and Telemedicine. Geneva, Switzerland: World Health Organization: 1997. WHO document EB99/INF.DOC/9.

${ }^{64}$ O. Adams. "International Trade in Health Services: Some Key Issues." Geneva, Switzerland: World Health Organization, 1997.

${ }^{65}$ David P. Fidler. (1995). "The Globalization of Public Health: Emerging Infections Diseases and International Relations." Indiana Journal of Global Legal Studies. (vol. 5):8.

${ }^{66}$ Allyn L. Taylor. (1992). "Making the World Health Organization Work: A Legal Framework for Universal Access to the Conditions for Health. American Journal of Law \& Medicine. (vol. 18):301-2.
} 
poverty" through the powerful conspiracy of certain important international institutions and the globalizing private sector. The World Bank tells us that the State, especially for African countries implementing [Structural Adjustment Programmes] SAPs, must get out of the way for market forces to take over. The consequences of this approach are enormous. Both in terms of the burden of communicable diseases and noncommunicable diseases, the developing world stands doomed. ${ }^{67}$

For Third World feminists, health actions are very much a political issue. ${ }^{68}$ Because Third World women are continually subjected to the policies promoted by transnational actors, such as the World Bank $^{69}$, each respective developing State continues to be preoccupied with population control. However, the control is placed mainly on women's bodies, especially poor women who are often perceived to be the root cause of 'over population. ${ }^{, 70}$ Renu Khanna has suggested that "the family and community members exert control over women's bodies by deciding when and how many children they should have. $^{71}$ Local women in Tamil Nadu, for example, are not only subjected to pressures within their own families and communities; but they also continually face pressures imposed upon them by World Bank policies which directly aim at regulating their daily reproductive and sexual functions. ${ }^{72}$ For feminists, health action aims at educating women to take charge over their own bodies thus controlling their reproductive and sexual lives. In order to ensure that local women are empowered, one must do research 'with' women rather than 'on' women. ${ }^{73}$ In this participatory method, the control at all

\footnotetext{
${ }^{67}$ Obijiofor Aginam, (2000). "Global Village, Divided World: South-North Gap and Global Health Challenges at Century's Dawn," Indiana Journal of Global Legal Studies (vol. 7): 627.

${ }^{68}$ Renu Khanna, "Research and Intervention: Insights from Feminist Health Action in Western India," in Marilyn Porter and Ellen Judd (eds.) Feminists Doing Development: A Practical Critique (New York: Zed Books, 1999), at 82.

${ }^{69}$ For a further analysis of the World Bank and Tamil Nadu please refer to the second section of this chapter.

${ }^{70} \mathrm{Id}$

${ }^{71} I d$

${ }^{73}$ Khanna, supra note 68 at 83.
} 
times remains in the hands of the local women and community health care workers, thereby ensuring that their reproductive and sexual rights are being respected, protected and promoted.

In sum, globalization has contributed to the erosion of the social welfare networks and further marginalized Third World women. National health systems and policies are increasingly being influenced by international factors that transcend national borders. In most of the Third World, transnational actors such as the World Bank control the 'population growth', and dictate population policy.

The next section of this Chapter examines how the policies of the World Bank impact the population policy of Third World countries. I give an overview of the mandate of the World Bank, and assess how the Bank's policies impact on Third World women's reproductive rights. This will demonstrate how the World Bank's population policies influence the family policies of Indian State, and by extension the policies of most Third World States. 


\section{The World Bank: Overview of its Mandate}

The World Bank is a vital source of financial and technical assistance to developing countries around the world. We are not a bank in the common sense. We are made up of two unique development institutions owned by 184 member countries-the International Bank for Reconstruction and Development (IBRD) and the International Development Association (IDA). Each institution plays a different but supportive role in our mission of global poverty reduction and the improvement of living standards. The IBRD focuses on middle income and creditworthy poor countries, while IDA focuses on the poorest countries in the world. Together we provide low-interest loans, interest-free credit and grants to developing countries for education, health, infrastructure, communications and many other purposes. $^{74}$

The World Bank is an international financial institution established in 1944 under the

Bretton Woods Agreement. It now assists with economic development, specifically in developing nations, by providing advance loans guaranteed by member governments. It is officially called the International Bank for Reconstruction and Development. ${ }^{75}$ The World Bank is the largest international source of development assistance. Its primary focus is in aiding the poorest people of the poorest countries. In 2002 the World Bank provided $\$ 19.5$ billion to developing countries and worked in more than 100 developing economies, bringing financial and/or technical expertise toward helping them reduce poverty. ${ }^{76}$ On a face reading of the Bank's mandate, it seems that the WORLD BANK is playing a humanitarian role in helping alleviate poverty in developing countries.

\footnotetext{
${ }^{74}$ http://web.worldbank.org/WORLD BANKSITE/EXTERNAL/EXTABOUTUS/0..pagePK:50004410 piPK:36602 theSitePK:29708,00.html accessed March 1, 2004

${ }^{75} \mathrm{http}: / /$ www.wordreference.com/English/definition.asp?en=World+Bank accessed March 1, 2004 ${ }^{76} \mathrm{http} / / /$ web.worldbank.org/WORLDBANKSITE/EXTERNAL/EXTABOUTUS/0, pagePK:43912 piPK:3 $6602,00 . \mathrm{html}$ accessed 29 February, 2004
} 
However, Vanada Shiva explains that the "World Bank is not really a bank that serves the interest of all the world's communities., 77

Rather, the Bank's decisions are based on:

voting weighted by the economic and political power of donors, [G-7, the group of the seven most powerful countries, dictate global affairs, but they remain narrow, local, and parochial in terms of the interests of all international communities] and in the decision making the communities that pay the real price and are the real donors have no say. ${ }^{78}$

Under the guise of humanitarian aid provided by the World Bank, Third World countries such as India have fallen victim to negative policies. In order to gain 'aid', developing countries must adhere to the policies dictated by the World Bank. Many Third World feminists argue that the Bank's introduction of structural adjustment programmes for developing countries in the early 1980s has negatively impacted those countries and lead to greater poverty. By the 1990s, the Bank had announced that their main focus would be poverty reduction. ${ }^{79}$ However, some feminists still perceive this as being long over due ${ }^{80}$ and argue that only in recent years has the World Bank's mission statement changed to: To fight poverty with passion and professionalism for lasting results. ${ }^{81}$

According to Chossudovesky:

Cost recovery and the application of user fees in health (also under World Bank supervision) also derogate women's rights to Reproductive Health.

\footnotetext{
${ }^{77}$ Shiva, supra note 27 at 22.

${ }^{78} \mathrm{Id}$

${ }^{79}$ World Bank, supra note 74.

${ }^{80}$ Carolyn M. Long, "The Advocate's Guide to Promoting Gender Equality at the World Bank." Women's Edge, Washington DC: women's Edge Printing, April 2003, at 2.
} 
The structural adjustment programmes have been conducive to the phasing out of maternal-child health programmes $(\mathrm{MCH})$. The evidence confirms a resurgence of maternal and infant mortality. In Sub-Saharan Africa, the tendency is towards the "de- professionalisation" of health services, ultimately leading to the collapse of primary health care. The Village Health Volunteers (VHV) and traditional healers have replaced the Community Health Nurses. The savings to the Treasury are applied to servicing the country's external debt. According to the World Bank, "informal health care" is not only "cost effective", it is more "democratic" because it "empowers" local communities in the running of village- based health centres. Ironically, the de-professionalisation of primary health care has also led to the concurrent breakdown of data collection on mortality and morbidity. In many countries, illiterate Village Health Volunteers are now responsible for the collection of health data with the consequent effect (and convenience) of lowering the rates of infant mortality recorded by governments and international organisations. ${ }^{82}$

Joseph Stighitz also states:

[t]he slowdown of the international economy could bring those countries that are tied to the dollar profound uncertainty with respect to their ability to compete on the global market. And the weakened economies of the United States and Japan are fueling a worldwide recession, which conspires against the economies of Latin America, he said. 'It used to be said that when the United States sneezed, Mexico caught a cold. With globalization, the United States sneezes and all Latin America, and much of the rest of the world end up with a bad case of the flu. Unfortunately, the United States now has pneumonia. ${ }^{, 83}$

Similarly, Baru and Jesani argue that "during the 1990s the World Bank has emerged as the single largest financier of health programmes in developing countries which are all part of the structural adjustment programme (SAP). ${ }^{, 84}$ They suggest that the Bank was prominent in health sector during the 1990s. It is partly due to the negative impact that

\footnotetext{
${ }^{82}$ Michel Choussudovesky. (March 30, 2006)."The World Bank Derogates women's Rights." The CLAIRE Foss Journals. Retrieved from http://www.cfoss.com/women.html

${ }^{83}$ Joseph Stighitz, (March 25, 2006). "Free Trade in the Americas is a Threat." Retrieved from http://www.globalpolicy.org/socecon/bwi-wto/wto/2001/1029ftaa.htm

${ }^{84}$ Rama Baru, and Amar Jesani. (2000). "The Role Of The World Bank In International Health: Renewed Commitment and Partnership," Social Science and Medicine. (vol. 5):183-4.
} 
SAP had on the health outcomes among vulnerable sections in the early adjusting countries. $^{85}$

\section{World Bank and Third World Population Control}

In recent years, many developed nation-states along with other transnational actors such as the World Bank have stressed the need for Third World States to control their surging populations. Negative connotations are apparent in developed (foreign-aid donor) State' policies in addressing Third World countries and their population. Lingam states that 'population 'boom', 'explosive' or problem are the terms often used when references are made to the growth of population in countries of the South." 86 Many Third World feminist movements are opposed to the idea, which prescribes 'population control as a solution.' According to Lingam, the women's movement attributes the present model of development [implemented by northern States], as being an unequal distribution of resources, and energy intensive technologies. ${ }^{87}$ Third World feminists place the blame on the affluent life style and consumption patterns of the rich in the north and consequently the South falls victim of poverty of people and nature. ${ }^{88}$ This results mainly because of the continual dynamics of globalization imposed upon Third World countries.

Since the 1950 s, a major international policy has been focused on limiting population growth especially from Southern countries. ${ }^{89}$ Grimes also sates the population control

\footnotetext{
${ }^{85} \mathrm{Id}$

${ }^{86}$ Laskshmi Lingam. (1995). "Reproductive Rights and More," .Radical Journal of Health. (Vol.1. no. 2): 136.

${ }^{87} I d$

${ }^{88} \mathrm{Id}$

${ }^{89} I d$
} 
lobby heavily funded by industrialized States, is changing its strategies towards investing in programmes to bring about cultural changes within societies. ${ }^{90}$ For example, to promote the World Bank's policies on population control in Third World communities, the Bank is now employing television 'soap operas' as the most effective means in achieving their end. One of the most heavily funded population control programmes through the medium of soap operas, has been the $\$ 45$ million grant to the John Hopkins University in the United States to design suitable programmes for Nigeria. ${ }^{91}$

With the ascendancy of globalization, it is seems that Third World countries are not only undergoing changes within their economies and health sectors but also culturally. With the employment of Westernized/American developed 'soap operas' this message is basically instructing Third World people specifically impoverished women to change their cultural, sexual and reproductive practices in order to resemble those of the industrialized countries. The World Bank policies of neo-imperialism becomes clear and of grave importance for many Third World feminists up in arms. The Cairo Action Plan ${ }^{92}$ states that activities promoting population control should not be carried out in a surreptitious way. Paragraph 11.23 of the Plan states that when the media, including radio and television soap operas are used 'for this advocacy purpose or to promote particular lifestyles, the public should be so informed and in each case the identity of sponsors

\footnotetext{
${ }^{90}$ Seamus Grimes, "Controlling Third World Population Growth: a major theme of the UN population conference in Cairo" Department of Geography National University of Ireland. http://www.hsph.harvard.edu/rt21/globalism/Grimes.html-47k accessed 20 February, 2004

${ }^{91}$ Id

${ }^{92}$ Please see next chapter for further information. The Cairo Plan of Action signifies an important step in the field of population policy, as it was the first time where international consensus addresses population as being entrenched in reproductive rights.
} 
should be indicated. ${ }^{93}$ In suggesting such policies it is evident that the international population lobby organizations are a new form of 'cultural imperialism' upon Third World nation-States. Transnational institutions such as the World Bank, are the agents of this cultural imperialism by dictating the reproductive and sexual functions of women in most of the Third World. Akhter describes the realities of the World Bank's policies towards Bangladeshi women as being extremely limiting. She argues that, the "Ford Foundation, Rockefeller Foundation, USAID, Pathfinder Fund, IPPF, World Bank, UNFPA are so "kind" to us in this particular issue that they grant huge amounts of money to our government so that we can buy Ovral and Norinlyfrom Weyth and Syntex laboratories, etc., buy IUD's from companies like A.H. Robins." 94 She suggests that Bangladeshi women are inundated with devices that harm their reproductive organs. ${ }^{95}$

The donors of foreign aid, especially the World Bank, have made it a pre-condition that Third World governments adhere to policies controlling their population growth. ${ }^{96}$ Population control has been apart of government policy since mid 1960s in Bangladesh. ${ }^{97}$ It is the 'poor' that are identified as being the 'problem,' therefore, programmes are designed to control their fertility." Akhter suggests that "the multinational pharmaceutical corporations producing a variety of contraceptives have found a large market in the bodies of [Third World] women, who are targeted for the distribution of the

\footnotetext{
${ }^{93}$ Id

${ }^{94}$ Farida Akhter, in "Reproductive Rights: A Critique from the Realities of Bangladeshi women" http://www.hsph.harvard, edu/grhf/SAsia/repro/farida.html (accessed 25 February, 2004)

${ }^{95}$ Id

${ }^{96} \mathrm{Id}$

${ }_{98}^{97} \mathrm{Id}$
} 
contraceptives imported from abroad." ${ }^{.99}$ If this is really how foreign aid is granted, why do Third World countries still continue to receive aid from such international institutions? This explains why women from Third World countries have long been critical of population lobbyists, who continually try to subject these women's reproductive functionalities by controlling the number of children they bear. World Bank policies have a negative impact upon population policies pertaining to Third World women.

Gita Sen argues that "State welfare policies, both historically and within contemporary times themselves a resultant of political forces, and have often reinforced the gender, class and race/ethnic disparities in societies thought the ways in which they have addressed or not addressed reproduction." ${ }^{\prime 100}$ In addressing such political forces, she suggests that "in the context of the International Conference on Population Division, women have had to thread their way among three sets of actors: the traditional population establishment; the fundamentalist's patriarchs; and the donor community, particularly the Bretton Woods institutions (that is, the World Bank and the International Monetary Fund). ${ }^{, 101}$

According to Sen, the shrinking entitlements of the poor; has not only class or race implications, but permeates policies with gender bias insofar as the costs of reproduction are shifted from the paid economy onto the unpaid labour of women. ${ }^{102}$

\footnotetext{
${ }^{99} \mathrm{Id}$

${ }^{100}$ Gita Sen, "Reproduction: The Feminist Challenge to Social Policy," in Power and Decision: The Social Control of Reproduction (Cambridge: Harvard School of Public Health, 1994), at 1-17.

${ }^{101}$ Gita Sen. (Jan/Feb, 1995). The Programme of Action: A New Paradigm for Population Policy. Environment. (vol. 37.no. 1):10-15 and 34-7.

${ }^{102}$ Sen, supra note, 100 at 2.
} 
She further suggests that even if entitlements are expanding, their distribution may be seriously biased by gender, class or race; and through carelessness on how the work of reproduction gets done. ${ }^{103}$ Finally, Sen states that even though reproduction is largely women's work, not all women may be engaged in doing it in quite the same way, due to class, race or other differences among them. ${ }^{104}$

Sen argues also that for more than a decade, [Third World] women's organizations and networks have also criticized the directions of contraceptive research and development and the abuses within family planning programmes. ${ }^{105}$ She further suggests that an important dilemma for women's organizations has been to work effectively in their criticism of existing programmes without aligning themselves with the deep-seated patriarchs who criticize family planning programmes from a perspective that denies women's rights. ${ }^{106}$ women from developing countries are beginning to challenge and protest against the North's domination and imposition of highly inequitable international economic arrangements where as Third World countries are forced into controlling the population growth or else risk not getting foreign aid. According to Sen women from Third World countries are being exploited by developed States and their population lobbyist agendas. ${ }^{107}$

The World Bank seems to be limiting Third World women's reproductive rights because the Banks policies are promoting gender mainstreaming. They are reinforcing the

\footnotetext{
${ }^{103} \mathrm{Id}$

${ }^{104} \mathrm{Id}$, at 3.

${ }^{105}$ Sen, supra note, 100 at 3.

${ }^{106} \mathrm{Id}$, at 5 .

${ }^{107} \mathrm{Id}$, at 9 .
} 
exclusion of disadvantaged women. Many Third World feminists believe that the World Bank policies have delegitimized public policy instruments for the implementation of social development policies and various forms of affirmative action policies, including the Beijing Platform for Action. ${ }^{108}$

World Bank policies on population control closely resemble family planning policies in India. According to the World Bank, group assistance has been provided to India dating back to the Bank's involvement in the population sector. ${ }^{109}$ Four population projects were prescribed and implemented between 1972 and $1986 .{ }^{110}$ In the $1990 \mathrm{~s}$, the Government of India began a shift from a system based on contraceptive method-specific and fertility reduction targets and monetary incentives to a broader system of performance goals and measures designed to encourage a wider range of reproductive and child health services. ${ }^{111}$ In places like Tamil Nadu under current population policies, this new approach towards family planning has been borrowed from the World Bank report, India's Family Welfare Programme: Toward a Reproductive and Child Approach. This is also evident in the case of the current National Population Policy 2000 (NPP) ${ }^{112}$.

In 1991-92, as a consequence of the government's effort to capitalize on fertility changes that were already occurring in Tamil Nadu, the State changed from pursuing methodspecific targets to a target-free approach. The programme emphasized the role of nurses,

\footnotetext{
${ }^{108}$ Long, supra note, 80 at vi.

${ }^{109}$ World Bank Report on "The World Bank Group and Population and Reproductive and Child Health in India" http://Inweb18.worldbank.org/sar/sa.nsf/0/0ala904791c49728525687b0062dca8?OpenDocument accessed (20/February, 2004)

$110 \mathrm{Id}$

${ }^{111} I d$

${ }^{112}$ For an in depth analysis of NPP please see the next chapter.
} 
midwives in the provision of contraceptive services, and workers were not pressed to fulfill sterilization targets. ${ }^{113}$ Measures of contraceptive prevalence in maternal and child health in the State indicate that the programme was partially successful. By 1995 , the use of contraceptive prevalence by all four methods offered (female sterilization, the Intra Uterine Device, oral contraceptives and condoms) had increased. ${ }^{114}$

India's family planning strategies tend to be paternalistic, prescriptive and coercive. It is a strategy that is based on the belief that the poor breed prodigiously and it is the Indian government's duty to hinder the unbridled fertility of impoverished women. ${ }^{115}$ The improvised rural woman has virtually no choice in this matter. She is at the mercy of the State, law and the medical practioners. These factors cannot be perceived as being neutral with regards to the negative experiences fueled by Indian women in accessing reproductive health. In these instances, the law actively imposes control of Indian women's bodies and directs the responsibility towards the doctor who must abide by policies reflective of those set forth by the World Bank.

The plan to reward 'panchayts' and 'zilla parishads' i.e. local government bodies at village and district levels, respectively for exemplary performance has no safeguards built-in to prevent ground-level coercion of poor women towards unwanted and/or unsafe sterilizations, intra-uterine device (IUD) insertions or other methods. According to Sen,

\footnotetext{
${ }^{113}$ Leela Visaria, Shireen Jejebhoy and Tom Merrick. (Jan, 1999). "From Family Planning to Reproductive Health: Challenges Facing India," in Family Planning Perspectives, Volume 25, Supplement.

${ }^{114}$ S. Ramasundaram, T. Rangarajan and S. Muthuramalingam, The Role of Political Will and Official Commitment in Tamil Nadu's Fertility Decline, Studies of Human Development in India, Discussion Paper Series, No. 24, Trivandrum, India: Centre for Development Research, 1997.

${ }^{115}$ Sen, supra note, 101.
} 
rewards to local government bodies "should not translate into ground-level coercion of (especially) poor women towards unwanted and unsafe sterilizations or IUD insertions." 116 The ethics of rewarding those 'below the poverty line,' either by providing health insurance or any other means provided they accept sterilization, is highly questionable. It seems that the Indian woman's claim to bodily autonomy is in direct conflict with her medically defined 'interests' imposed from within by the State, and externally by international actors such as the World Bank. This control reflects a paternalistic view, where there is refusal to grant women the necessary means in making mature, rational reproductive decisions.

By placing conditionalities, this reinforces an attitude among foreign donors, health care providers and politicians that poor women and girls deserve nothing better. The State is implicated in these conditionalities in so far it supports the implementation of stronger incentives and even disincentives which are reflective of World Bank policies.

Despite the success found in Chengalpattu, Tamil Nadu, women are still continuing to be sterilized in large numbers in Tamil Nadu. According to statistics "by 2002, nearly 44 percent of Tamil Nadu's women had borne two children and been sterilized before their 27th birthday." 117 As well, the State's total fertility rate had dropped from 3.8 in 1976 to 2.0 in 2002. ${ }^{118}$ According to Margot Cohen, the events which occurred after 2004 December's Indian Ocean tsunami which killed over 2,300 children in Tamil Nadu, and

\footnotetext{
${ }^{116} \mathrm{Id}$

${ }^{117}$ Government of Tamil Nadu, Department of Health and Family Welfare, Directorate of Family Welfare, 2002 Annual Report (Chennai, India: Government of Tamil Nadu, 2003).

${ }^{118}$ Office of the Registrar General, India, Sample Registration Statistical Report2002 (New Delhi, India, 2004).
} 
the State government began offering free reversals of tubal ligation for women who wished to conceive again is very interesting. "More than a dozen tsunami survivors in Tamil Nadu have already had recanalization, but most of the other patients are expected to undergo the procedure in late June and July. Cohen writes that "Tamil Nadu's Chief Minister, Selvi J. Jayalalithaa, added a political gloss to the drive by appearing on television to publicize an executive order that promised either free recanalizations at government hospitals or 25,000 rupees $(\$ 595)$ in compensation for those who opt for private clinics. This brought forth concern that the high-profile programme feeds into broad cultural biases that only validate women if they bear children." 119

\section{Conclusion}

In examining how globalization limits Third World women locally, one needs to understand how globalization constraints Third World nation-States. The raison d'etre of government policy is to protect the rights of its citizens. Yet under the current global conditions, policy choices often favour the interests of influential transnational actors and capital gains. In this environment, it is not surprising that globalization is an impetus for economic growth and investment. In such cases, the interests of the industrialized donor countries take precedence, where there is a shift in priority to economic growth, capital interests and large-scale development rather than focusing on social issues which affect have a gendered perspective. Therefore governments, especially in Third World countries, have started adapting to this new regime where public spending towards social

\footnotetext{
119 Margot Cohen, "After the Tsunami, A Drive to Reverse Tubal Ligations in Tamil Nadu" http://www.prb.org/Template.cfm?Section=PRB\&template=/ContentManagement/ContentDisplay.cfm\&C ontentID $=12649$ (visited: $25 / 11 / 05$ )
} 
services is extremely limited. As well under such conditions the foundations that construct citizenship are eradicated.

In response to these recent developments initiated by various global factors, Third World feminists are challenging the current economic status quo. They believe that in order to produce a climate where sustainable and equitable economies reflect the pluralism of the Third World feminist agenda, immediate changes have to be made towards: transforming mainstream economics; challenging the World Bank; influencing corporate behaviours; lobbying national governments; and fostering participatory economics. ${ }^{120}$.

Therefore, it is important to fully integrate Third World perspectives into theoretical and practical analyses of international feminism, especially pertaining to reproduction and sexuality. Without such collaborative measures, this would only lead to partial solutions and further marginalization of these women will continue. It is very important that Third World discourse be integrated in critiquing transnational financial actors such as the World Bank. Without these voices being heard, the arguments pertaining to globalization and reproductive health will reflect the ethnocentric biases, which continue to dominate the international sphere.

women in South America, Asia, and Africa are all subjected to these limitations imposed by the World Bank. Such policies continue to reinforce gender, class and race-based divisions of labor throughout the Southern States. This imposes significant costs on many

\footnotetext{
${ }^{120}$ Joanna Kerr, "Responding to Globalization: Can Feminists Transform Development?" in Marilyn Porter and Ellen Judd (eds.) Feminists Doing Development: A Practical Critique (New York: Zed Books, 1999), at $193-4$.
} 
Third World women, and constrains their reproductive and sexual rights. Health, development and human rights must all play an intrinsic part in the impact of globalization. In order to reach such goals, the donor States must respect the reproductive 'self determination' of Third World women. For these women, their health is essential in protecting their own families and their communities. In order to pursue effective reproductive/sexual rights programmes in India, the policies must direct domestic governments (at all levels) towards adhering to international instruments that protect and empower women to make reproductive choices. In order to obtain a level of successful reproductive choices, policies should positively target the poor women at all levels of government, without providing incentives/disincentives which is a problem within the current family planning policy.

Marginalized women should be allowed an opportunity to design, implement and monitor programmes. By granting women from these communities an opportunity to participate in the policy arena, they will be able to make positive changes, which affect their lives directly. women become further empowered to take control over their reproductive/sexual rights. Sustained assistance for public social services such as universal gender sensitive academic and health education (targeting both men and women) should be an important component. Men should be urged to take part in learning about reproductive health issues and that the onus does not lie on women with regards to reproductive rights. They must adhere to gender equality, renounce violence against women, and support women's reproductive/sexual health and rights. 
In summary, this chapter explored Third World feminist discourse to assess how globalization is negatively limiting the reproductive and sexual rights of Third World women. Neo-liberalist polices privileges private corporate development often in the guise of "foreign donors" such as the World Bank. Globalization has contributed to the erosion of the social welfare networks and further marginalized Third World women as in the case of India. Developing countries such as India have few alternatives by declining the implementation of World Bank designed macroeconomic reforms. If Third World countries do not carry out the policies prescribed by the World Bank, they risk losing future loans, and or partial debt relief.

The next chapter focuses on the women's reproductive human rights policies at the national and international levels. Chapter Four builds on the themes already addressed in this chapter focusing on how India's National Population Policy 2000 replicates the World Bank's population policy programme agenda. 


\section{Chapter Four \\ The Intersection between International Human Rights Instruments and National Population Policy}

[R] eproductive rights embrace certain human rights that are already recognized in national laws, international human rights documents and other consensus documents. These rights rest on the recognition of the basic right of all couples and individuals to decide freely and responsibly the number, spacing and timing of their children and to have the information and means to do so, and the right to attain the highest standard of sexual and reproductive health. It also includes their right to make decisions concerning reproduction free of discrimination, coercion and violence, as expressed in human rights documents (Beijing Declaration and the Platform for Action, UN Fourth World Conference on women, 1996)..$^{121}$

This Chapter examines how women's reproductive human rights are applied at both the international and national levels. This analysis focuses on the Indian National Population Policy 2000 (NPP). I apply Third World feminist theory to the translation of international human rights provisions, specifically pertaining to women's reproductive rights, into national population policy. First, I describe various international human rights instruments and how they protect the rights of women and girls, especially how they are reinforced by the Cairo Programme of Action and the Beijing Declaration and Platform of Action, which predominantly focus on reproductive freedom for women. Secondly, I draw from Third World feminist discourse to argue that the national implementation of these international policies in India is discriminatory towards women. Finally, I examine whether India's National Population Policy does limit women's reproductive sexual rights. I will argue that despite the various international human rights instruments protecting women's rights, the National Population Policy of India does limit women's reproductive choices. Themes explored in Chapter Three especially

\footnotetext{
${ }^{121}$ Beijing Declaration and the Platform for Action, Fourth World Conference on women, UN Doc. A/CONF.177/20 (1996), Beijing, China, September 4-15 1995 [hereinafter Beijing Declaration and Platform for Action], para. 95.
} 
globalization and the neo-liberal policies of transnational actors like the World Bank are recurrent, and will be explored further in this chapter.

\section{International Human Rights Instruments ${ }^{122}$}

Internationally, various institutions, especially the United Nations (UN) have exerted pressure over States with regards to human rights, in particular those of women and girls in the past two decades. ${ }^{123}$ The UN Declaration recognizes that human rights of women and of the "girl-child" are an, "inalienable, integral and indivisible part of universal human rights" ${ }^{\prime 124}$. The concept of women's human rights has enabled women to ask questions about the official, "inattention and general indifference to the widespread discrimination and violence that women experience." $" 125$ women have demanded that their access to reproductive health be a subject of international human rights law. ${ }^{126}$ These demands were articulated in the 1994 UN Conference on Population and Development in Cairo, and the 1995 Fourth UN World Conference on women in Beijing. These two conferences, formally recognized at the international level that the protection of reproductive and sexual health is a matter of social justice, which could be achieved

\footnotetext{
${ }^{122}$ Human rights can be distinguished between negative and positive human rights. All human rights are negative rights, in the sense that they only require governments to refrain from doing things. In this view, human rights never require governments to take positive steps such as protecting and providing. While positive human rights means that governments intervene by providing affirmative acts to facilitate the enjoyment of rights. Moreover, when it is Stated that human rights are inalienable, this does not mean that rights are absolute or can never be overridden by other considerations.

http://plato.stanford.edu/entries/rights-human/ (visited: 06/06/05)

${ }^{123}$ Fourth Conference on women, 21 June, 1995. (30 March, 2006). Retrieved from http://www.un.org/esa/documents/ga/confl 77/aconfl 77-7en.htm.

${ }^{124}$ Vienna Declaration and Programme of Action, Para. 18. www.treatycouncil.org/section_21149.htm $108 \mathrm{k}$ (visited: 03/03/03)

${ }_{125} \mathrm{http} / / /$ www.cwgl.rutgers.edu/whr.html (visited 03/03/03)

126 "From Vienna to Beijing: The Cairo Hearing on Reproductive Health and Human Rights." The Cairo Hearing is a compilation of six testimonies from around the world addressing reproductive health and human rights violations. These were presented at the NGO Forum of the 1994 International Conference on Population and Development in Cairo, Egypt, September 1994.
} 
through the application of human rights codified in existing national legislators and international treaties. ${ }^{127}$

Before examining the different human rights instruments which protect the sexual and reproductive interests, it is important to define the term reproductive health:

A condition in which the reproductive process is accomplished in a State of complete physical, mental, and social well being and is not merely the absence of disease and disorders of the reproductive process. Reproductive health, therefore, implies that people have the ability to reproduce, to regulate their fertility and to practice and to enjoy sexual relationships. It further implies that reproduction is carried to a successful outcome through infant and child survival, growth and healthy development. It finally implies that women can go safely through pregnancy and childhood, that fertility regulation can be achieved without health hazards and that people are safe in having sex. ${ }^{128}$

The Constitution of the World Health Organization (WHO), defines health as "a State of complete physical, mental, and social well-being and not merely the absence of disease or infirmity." 129 An important purpose of human rights law is to protect women from unnecessary medicalization of their sexuality and reproductive capacities. ${ }^{130}$ The right to health is a human right that typically relates to the overall category of "social rights," which include economic, social and cultural rights. ${ }^{131}$

As argued by Mann et al, there are many essential characteristics found within contemporary human rights. These include:

[r]ights of individuals; these rights inhere in individuals because they are human; they apply to all people around the world; and they principally involve the relationship between the State and the individual. The specific rights which form the corpus of human rights law are listed in several key

\footnotetext{
${ }^{127}$ R. J. Cook, Bernard M. Dicken, and Mahmoud F. Fatahlla. Reproductive Health and Human Rights: Integrating Medicine, Ethics and Law. Oxford: Claredon Press, 2003 at 148-149.

${ }^{128}$ Constitution of the World Health Organization. http://www.who.int/en/ (Visited:04/01/03) ${ }^{129} I d$.

${ }^{130}$ A.Hendriks. (1995). A Selected Bibliography of Human Rights and Disability. Health and Human Rights. (vol. 1.no. 2), 212-25.

${ }^{131}$ Id at 213.
} 
documents: foremost is the Universal Declaration of Human Rights (UDHR), which, along with the United Nations Charter (UN Charter), the International Covenant on Civil and Political Rights (ICCPR) and its Optional Protocols and the International Covenant on Economic, Social and Cultural Rights (ICESCR), constitute what is often called the "International Bill of Human Rights." The UDHR was drawn up to give more specific definition to the rights and freedoms referred to in the UN Charter. The ICCPR and the ICESCR further elaborate the content set out in the UDHR, as well as setting out the conditions in which States can permissibly restrict rights. ${ }^{132}$

Health issues have been recognized as being a fundamental human right, in the Universal Declaration of Human Rights (1948), and the Constitution of the World Health Organization (1946). However, due to their specific focus on women's rights, this analysis will focus on the Beijing Platform for Action, the Cairo Programme, the International Covenant on Economic, Social and Cultural Rights (The ICESCR), and the Convention on the Elimination of All Forms of Discrimination Against women $(\mathrm{CEDAW}){ }^{133}$

The recognition of fundamental human rights is reflected in international instruments such as CEDAW which states the following:

\section{Equality in access to health facilities}

\section{Article 12}

\footnotetext{
132 Jonathan M. Mann et al. (Fall 1994). "Health and Human Rights," Health and Human Rights: An International Journal, (Vol. 1, No. 1).

http://www.hsph.harvard.edu/ fxbcenter/VIN1 mannetal.htm (visited: 06 May 2005)

${ }^{133}$ India ratified The Economic Covenant on $10 \mathrm{Apr} 1979$. (for greater detail please see http:www.un.org.Depts/Treaty/final/ts2/newfiles/part_boo/iv_boo/iv_3.html. Also India ratified $C E D A W$ DISCRIMNATION AGAINST WOMEN States that have signed, ratified, acceded or succeeded to the Convention. 8 October 1999. (Visited: 03/01/30)
} 
1. States Parties shall take all appropriate measures to eliminate discrimination against women in the field of health care in order to ensure, on a basis of equality of men and women, access to health care services, including those related to family planning.

2. Notwithstanding the provisions of paragraph 1 of this article, States Parties shall ensure to women appropriate services in connection with pregnancy, confinement and the post-natal period, granting free services where necessary, as well as adequate nutrition during pregnancy and lactation.

Access to health care is a problem affecting women, men and children in many areas of the world. However, as recognized in article 12, women in particular, by virtue of their unequal status and their special vulnerabilities, encounter a great many obstacles in obtaining adequate health care.

Paragraph 1 of article 12 specifically requires States parties to ensure the equality of women and men in access to health care services. This requires the removal of any legal and social barriers which may operate to prevent or discourage women from making full use of available health care services. Steps should be taken to ensure access to health care services for all women, including those whose access may be impeded through poverty, illiteracy or physical isolation (see also "Rural women", p. 25 below). ${ }^{134}$

Article 12 demonstrates a significant change towards shaping the normative contents, as well as the legal elements of the right to women's reproductive health. This is significant for women because, as Hendricks argued women are more vulnerable to human rights violations especially pertaining to their health (reproductive issues) due to repressive laws found globally. ${ }^{135}$ However, there has been an international reappraisal of health as a human rights issue, and the current terminology reflects women's right to sexual and reproductive health rather that just being gender neutral. ${ }^{136}$ Although international human rights instruments such as the ICESCR and CEDAW explicitly cover a women's right to health, only minimal efforts have been made by individual States to legislatively articulate the meaning of this right, and this is apparent in the case of India. India made a reservation to CEDAW in the following items: "With regard to article 29 of the

\footnotetext{
${ }^{134}$ Fact Sheet No.22, Discrimination against women: The Convention and the Committee, Vienna Declaration and Programme of Action, (part I, para. 18) adopted by the World Conference on Human Rights, Vienna, 25 June 1993 (A/CONF. 157/24 (Part I), chap. III) http://www. unhchr.ch/html/menu6/2/fs22.htm (visited: 09/09/05) ${ }^{135} \mathrm{Id}$ ${ }^{136} \mathrm{Id}$.
} 
Convention on the Elimination of All Forms of Discrimination Against women, the Government of the Republic of India declares that it does not consider itself bound by paragraph 1 of this article."137

I will first discuss how the ICESCR sets out the principles that protect reproductive rights of women under international law. The right to health is an intrinsic component of the ICESCR, which codifies the State's responsibility in protecting and promoting women's health. ${ }^{138}$ When speaking of rights, it seems that States find it much easier to comply with negative rights (rights that oblige the State to refrain from interfering with individual freedoms) rather than positive rights (rights that require actual State action). ${ }^{139}$ With regards to women's human rights, there are both universal positive and negative rights (various international instruments), and the onus lies on the respective State to adhere to these rights if it interferes with the treaty. The health rights provided in the ICESCR are outlined in Articles 10 and 12 of the Covenant ${ }^{140}$

Article 10.2 Special protection should be accorded to mothers during a reasonable period before and after childbirth.

Article 12.1 The States Parties to the present Covenant recognize the right of everyone to the right of the highest attainable standard of physical and mental health.

\footnotetext{
${ }^{137}$ Any dispute between two or more States Parties concerning the interpretation or application of the present Convention which is not settled by negotiation shall, at the request of one of them, be submitted to arbitration. If within six months from the date of the request for arbitration the parties are unable to agree on the organization of the arbitration, any one of those parties may refer the dispute to the International Court of Justice by request in conformity with the Statute of the Court. Declarations and reservations by India made upon ratification, accession or succession of the CEDAW http://sim.law.uu.nl/SIM/Library/RATIF.nsf/0/3879720615d692a4c12568b900451c40?OpenDocument (visited:19/08/2005)

${ }^{138}$ International Covenant on Economic, Social and Cultural Rights (1966) 993 U.N.T.S. 3, 1976 Can. T.S.No.46, in force

${ }^{139}$ Hendricks, supra note 130 at 214.

${ }^{140}$ International Covenant on Economic, Social and Cultural Rights (1966) 993 U.N.T.S. 3, 1976 Can. T.S.No.46, in force
} 
Article 12.2 The steps to be taken by the States Parties to... achieve the full realization of this right shall include those necessary for: (a) The provision for the reduction of the stillbirth rate and of infant mortality and for the healthy development of the child;... (d) The creation of conditions which would assure to all medical service and almedical attention in the event of sickness.

The following illustrates the components of the Convention on the Elimination of All Forms of Discrimination Against women (CEDAW) that explicitly refer to the explicitly women's right to health, specifically reproductive rights:

Article 10 (h) [States Parties shall ensure] [a]cess to specific educational information to help to ensure the health and well being of families, including information and advice on family planning.

Article 12.1 States Parties shall take all appropriate measure to eliminate discrimination against women in the field of health care in order to ensure, on a basis of equality of men and women, access to health care services, including those related to family planning.

Article 12.2 States Parties shall ensure to women appropriate services in connection with pregnancy, confinement and the post natal period, granting free services where necessary, as well as adequate nutrition during pregnancy and lactation.

Article 14.2 States Parties shall take all appropriate measure to eliminate discrimination against women in thural areas [and] ensure to such women the right:... (b) To have access to adequate health care facilities, including information, counseling and services in family planning [.]

Finally, Article 19 States that "States Parties should prevent coercion in regards to fertility and reproduction, and should ensure that women are not forced to seek unsafe medical procedures, such as illegal abortions, because of lack of appropriate fertilitycontrol."141

\section{Reproductive Freedoms}

As mentioned previously, the Cairo Programme of Action of $1994^{142}$, and the Beijing Declaration and Platform of Action ${ }^{143}$ are two instruments which have furthered the cause

\footnotetext{
${ }^{141} I d$.

${ }^{142} \mathrm{http} / /$ www.iisd.ca/linkages/CAiro/programme/p00000.html for greater detail (Visited: 03/03/03)
} 
of reproductive rights internationally. The Cairo Programme of Action was implemented due to major shifts in attitude among world leaders with regard to reproductive health, including family planning and sexual health. ${ }^{144}$ The Cairo Programme sets out targets ${ }^{145}$ whereby States must agree to make accessible reproductive health to all individuals of appropriate ages through their primary health care systems. ${ }^{146}$ The Beijing Platform which evolved from the positive measures outlined in the Cairo Programme, recognizes women's reproductive interest by agreeing, for instance, to consider "reviewing laws containing punitive measures against women who have undergone illegal abortions." 147

Key Provisions of the Beijing Platform for Action

Paragraph 89 women have the right to the enjoyment of the highest attainable standard of physical and mental health. The enjoyment of this right is vital to their life and wellbeing and their ability to participate in all areas of public and private life. Health is state of complete physical and mental well-being and not merely the absence of disease or infirmity.

Paragraph 92 women's right to the enjoyment of the highest standard of health must be secured throughout the whole life cycle in equality with men.

Paragraph 223 [T] he Fourth World Conference on women reaffirms that reproductive rights rest on the recognition of the basic right of all couple and individuals to decide freely and responsibly the number and spacing and timing of their children and to have the information and means to do so. ${ }^{148}$

Although both of these aforementioned documents are not legally binding in international law, they do hold great authority as "soft law" since they have been endorsed by majority of States ${ }^{149}$, including India. By endorsing the Beijing Declaration and the Platform of

\footnotetext{
${ }^{143} \mathrm{http}: / /$ www.iccwomen.org/reports/b+5/ for greater detail(Visited: 03/03/03)

${ }_{144}$ Maja Kirilova Erikson, Reproductive Freedom: In the context of International Human Rights and Humanitarian Law, (Sweden: Martinus Nijohoff, 2000) at 172-73.

${ }^{145}$ For greater detail on targets set out in The Cairo Programme please see: supra note 19.

${ }^{146} \mathrm{http}: / /$ www.iisd.ca/linkages/CAiro/programme/p00000.html (Visited 03/04/03)

${ }_{147} \mathrm{Id}$.

${ }^{148} \mathrm{Id}$.

${ }^{149}$ Approximately 180 governments agreed upon the Cairo Programme of Action. One hundred and eighty nine countries adopted the Beijing Declaration and the Platform of Action unanimously. Please see, UN
} 
Action, India has expressed a commitment to "ensure equal access to and equal treatment of women and men in education and health care and enhance women's sexual and reproductive health as well as education." 150 These instruments significantly influence those States that participated in the aforementioned conferences, even if those States are not parties to CEDAW, and other human rights treaties. ${ }^{151}$ In addition, feminist legal scholars hope that the aforementioned instruments will raise public awareness and consciousness, thus stimulating positive changes within the States. ${ }^{152}$

The next section looks at how even though India is a signatory to the aforementioned legal instruments; the National Population Policy 2000 is weak on many counts in terms of promoting save reproductive and sexual rights.

\section{National Population Policy 2000}

Today, India's population has crossed the one billion mark. This is a serious matter that is both cause for concern and introspection - concern over the impact that a runaway population growth is bound to have on the nations' economic, natural, and other resources; introspections over where we went wrong and how we can stabilize our population [...] Bearing this in mind, and realizing the urgency of the need to stabilize our population, Government has adopted a National Population Policy and set up a broad based Population Commission to monitor the implementation of this policy. ${ }^{153}$

It appears that there is an increase in controlling the deployment of power over Indian women thus providing a more efficient way of managing their 'private sphere' of their

GA Res. 19/128 of December 1994; GA Res. 50/124 of 20 December 1995 and GA Res. 50/203 pf 23 February 1996.

${ }^{150}$ Fourth World Conference on women Beijing Declaration, http://www.un.org/womenwatch/daw/beijing/platform/declar.htm (visited: 10/11/05)

${ }^{151}$ Eriksson, supra note 144 at 25.

${ }^{152} I d$.

${ }^{153}$ Statement by the Prime Minister, Atal Behari Vajpayee on the occasion of India's population crossing the one billion New Delhi May 11, 2000

http://www.indianembassy.org/s[pecial/cabinet/Primeminister/pm may 11_2000.html (Visited: 30/04/03) 
sexuality. This policy applies knowledge/power upon Indian women thus controlling their reproduction, thereby inhibiting Indian women's access to reproductive rights. The Indian current population policy demonstrates that Indian women are reduced to their biological functions.

The National Population Policy 2000's (NPP) main goal is to confirm the commitment of the central government towards 'voluntary and informed choice and consent' of citizens while benefiting reproductive health care services and continuation of the 'targets free approach' in governing family planning services throughout India. ${ }^{154}$ The NPP presents a policy framework for enhancing goals and prioritizing strategies during the next ten decades, in order for India to meet the reproductive and child health needs, and to attain net replacement levels (TFR) by $2010 .^{155}$ Its foundation is to simultaneously tackle issues of child survival, maternal health, and contraception, while expanding outreach and coverage of a comprehensive package of reproductive and child health services by the central government, industry and the voluntary non-government sector, all working in partnership. ${ }^{156}$ It seems that there exists control over the Indian subjects within which issues of individual sexuality and reproductive conduct are interconnecting with issues of national policy (NPP). Through constant surveillance, it also becomes visible that the Indian women are subjected to control and a body of knowledge about their reproductive function is created. Consider the following NPP policy:

\footnotetext{
${ }^{154}$ National Population Policy, supra note 153.

${ }^{155} \mathrm{Id}$.

${ }^{156} \mathrm{Id}$.
} 
The immediate objective of the NPP 2000 is to address the unmet needs for contraception, health care infrastructure, and health personnel, and to provide integrated services delivery for basic reproductive and child health care. The medium-term objective is to bring the TFR to replacement by 2010, through vigorous implementation of inter-sectoral operational strategies. The long-term objective is to achieve a stable population by 2045 , at a level consistent with requirements of sustainable economic growth, social development, and environmental protection. ${ }^{157}$

After the 1994 UN Population Conference in Cairo, India began dismantling its oppressive sterilization programme, which targeted poor women. ${ }^{158}$ However, female sterilization still accounts for about three-fourths of contraceptive practice in India. ${ }^{159}$ The Minister for Health and Family Welfare, Shri Shatrughan Sinha, when addressing a two-day Colloquium on 'Population Policy-Development and Human Rights' in January 2003 stated that "The National Population (NPP) aims at providing the widest range of services without any form of coercion."160 Nonetheless, under the NPP 2000, new measures have been proposed by the government as "incentive schemes which would give health insurance to these below the poverty line who agree to be sterilized after two children and special rewards to local government units which achieve an 'exemplary performance' in universalizing the small family norm." "161 Indian feminists such as

\footnotetext{
${ }^{157}$ National Population Policy, supra note 153.

${ }^{158}$ Betsy Hartmann, "Population Policy: Will Coercion Come Back in Vogue?" ZNET Daily Commentaries. May 12000 www.zmag.org/sustainers/content/2000-05/01 hartmann.htm - 14k - 9 Apr 2003 (Visited: 09/04/03)

${ }^{159}$ Id.

${ }^{160}$ Please see http://nhrc.nic.in/Declaration(Final).doc (Visited: 07/04/03)

${ }^{161} \mathrm{Id}$. Interestingly States do not always look for measures in reducing fertility. In the case of Quebec, Canada, women are provided incentives in order to promote the population growth Quebec. Please see Kevin Milligan, Quebec's baby Bonus: Can Public Policy Raise Fertility? (C.D. Howe Institute: Canada). January 24, 2002. In 1988 the Quebec government introduced the Allowance for New World Bankorn Children, a pro-natalist child benefit which paid up to $\$ 8000$ to a family after the birth of a child. Between 1989 and 1996 fertility among Quebec women rose close to $86 \%$
} 
Kalpana Sharma and Gita Sen, warn that such policies may negatively impact Indian women. $^{162}$

By decentralizing the planning and the programme implementation, the NPP takes a bottom up approach towards population policy in India. The $73^{\text {rd }}$ and $74^{\text {th }}$ Constitutional Amendments Act, 1992, made health, family welfare, and education a responsibility of village panchayats. ${ }^{163}$ The panchayati raj institutions are an important means of furthering decentralized planning and programme implementation in the context of the NPP 2000. ${ }^{164}$ According to the Indian central government the panchayats demonstrate an exemplary performance in the mandatory registration of births, deaths, marriages, and pregnancies, universalizing the small family norm, increasing safe deliveries. Also the panchayats enable reductions in infant and maternal mortality, and promote compulsory education up to age 14 , which will be nationally recognized and honored. ${ }^{165}$

While family welfare is a centrally funded and directed programme, States have responsibility for health, and education is a concurrent subject, handled by both Central and State governments. ${ }^{166}$

As mentioned in Chapter Three, the plan to reward panchayats and zilla parishads for exemplary performance illustrates lack of safeguard measures to prevent and groundlevel coercion of poor women towards unwanted and/or unsafe sterilizations, intra-

\footnotetext{
162 Hartmann, supra note 158.

163 National Population Policy, supra note 157.

${ }^{164} I d$.

${ }^{165} I d$.

${ }^{166}$ Gita Sen, "A Comment on India's National Population Policy 2000." Re: cyber-fem: welcome/Sen on India's Pop. Policy. May 008 2000. http://www.hsph.harvard.edu/rt21/archives/200005/msg00010.html (Visited: 07/04/03)
} 
uterine device (IUD) insertions or other methods. According to Sen, rewards to local village government bodies should avert from enforcing ground-level coercion of poor women especially pertaining to unsafe reproductive choices. The ethics associated with rewarding those 'below the poverty line,' and by providing them health insurance or other incentive compels these marginalized women into accepting sterilization. It seems that the Indian woman's claim to bodily autonomy is in conflict with her medically defined 'interests' imposed upon her by the State, law and medicine. This control reflects a paternalistic view, where there is a refusal to grant women the necessary means in making mature, rational reproductive decisions. Such conditionalities demonstrated in the NPP continue to reinforce an attitude among policy makers that poor women and girls can be taken out of the equation while examining family planning policies. Furthermore, these condionalities can further enable State governments to have greater power over enforcing such negative policies upon poor women.

The Indian Government States that nearly 100 million people live in urban slums, with little or no access to potable water, sanitation facilities, and health care services. ${ }^{167}$ Basic and primary health care, including reproductive and child health care, needs to be provided at the community level thus enabling access by the poor. As mentioned in Chapter Three, the National Population Policy closely replicates the World Bank population policies. ${ }^{168}$ Accordingly, Amit Sen Gupta states that linking social security access with demographic objectives is a major agenda of the World Bank-limiting the

\footnotetext{
${ }^{167}$ Dr. Amit Sen Gupta, Population Control and Contraception Choice: women and Health-Myth of Population Control. www.sochara.compdfs/pha shamiana sessions.pdf. (Visited: 04/07/03)

${ }^{168}$ See World Bank report, (1995). India's Family Welfare Programme: Toward a Reproductive and Child Health Approach. (Report no. 14644-IN). www.worldbank.org/ EXTDEVCOMMENG/Resources/spanishtoolkit.pdf - (visited: 04/07/03)
} 
States expenditure in social infrastructure areas and food and security. ${ }^{169}$ The NPP policy is:

[A]n innovative package of incentives/disincentives would be formulated with emphasis on community-based incentives and social security measures for individuals adopting small family norm. The communitybased incentives would be linked to various benefits being made available to the public under different socio-economic development plans of the government. 170

The NPP report is really not addressing a reduction in coercive methods in family planning programmes aimed at the poor but an increase in this procedure. Moreover, linking up incentives/disincentives with social security measures and social economic development plans presents a clear indication of how access to social security measures will be made upon conditional adherence to State prescribed family planning goals. ${ }^{171}$

In general, populations in remote and low-density areas do not have adequate access to affordable health care services. Tribal populations often have high levels of morbidity arising from poor nutrition, particularly in situations where they are involuntary displaced or resettled. ${ }^{172}$ They have low levels of literacy, coupled with high infant, child, and maternal mortality. They remain under-served in the coverage of reproduction and child health services. ${ }^{173}$ The NPP advocates that these communities need special attention in terms of basic health, and reproductive and child health services. The special requirements of tribal groups should be addressed including the provision of mobile clinics that will be responsive to seasonal variations in the availability of work and

\footnotetext{
${ }^{169}$ Sen, supra note 166 .

${ }^{170} \mathrm{Id}$.

${ }^{171}$ National Population Policy, supra note 157.

${ }^{172}$ Gupta, supra note 167.

${ }^{173}$ National Population Policy, supra note 157.
} 
income. ${ }^{174}$ The family planning strategies illustrated in the NPP tend to be paternalistic, prescriptive and coercive. It is a strategy that is based on the belief that the poor breed prodigiously and it is the Indian government's duty to hinder the fertility of women. ${ }^{175}$ The impoverished rural woman has virtually no choice in this matter. She is at the mercy of the State, law and the medical physicians. These factors cannot be perceived as being neutral with regards to the negative experiences Indian women face in accessing reproduction health. In these instances, law actively imposes control of Indian women's bodies and directs the responsibility towards the physician.

The NPP policy states that the voluntary non-governmental and private corporate sectors should actively collaborate with the community and government through specific commitments in the areas of basic reproductive and child health care, basic education, and in securing higher levels of participation in the paid work force for women. This section of the NPP requires strengthening and developing instruments for feedback, programme quality assurance, and organizational learning. ${ }^{176}$ According to Sen, the approach to partnerships with NGOs does not place in the vanguard methods to address NGO concern about the limited role they are expected to play, and the fact that their ability to innovate, and to provide useful feedback and monitoring is not being adequately recognized. ${ }^{177}$ Sen further states that "various groups, including parliamentarians and non- governmental organizations (NGOs), have argued that moving towards disincentives

\footnotetext{
${ }^{174} \mathrm{Id}$

${ }^{175} \mathrm{Id}$

${ }^{176}$ Gita Sen, "A Comment on India's National Population Policy 2000." Re: cyber-fem:welcome/Sen on India's Pop. Policy. May 08 2000. http://www.hsph.harvard.edu/rt21/archives/ 200005/msg00010.html (Visited: 04/07/03)

${ }^{177} \mathrm{Id}$.
} 
would once again direct policy and programmes away from what is the heart of the problem in the country" 178 (poor quality and inaccessible health -including family welfare-services), the need or effective public health, including reproductive and sexual health services, and the gender inequality that leaves many Indian women with so little control over their health and lives.

Moreover, she argues that the policy does not address two important dimensions adequately: "how to promote gender equality and equity in programmes, and how to ensure serious implementation of a participatory and bottom-up approach based on an assessment of community needs, and capacity-building among service personnel, their supervisors, and the communities and the women they are expected to serve."179 These have now emerged in the context of the last few years implementing a target-free reproductive and child health programme as a major weaknesses in the current. ${ }^{180}$

Finally, in the past, population programmes have tended to exclude men. The Indian government argues that gender inequalities in patriarchal societies ensure that men play a critical role in determining the education and employment of family members, age at marriage, besides access to and utilization of health, nutrition and family welfare services for women and children. ${ }^{181}$ The active involvement of men is called for in planning families, supporting contraceptive use, helping pregnant women stay healthy, arranging skilled care during delivery, avoiding delays in seeking care, helping after the baby is

${ }^{178} I d$.
${ }^{179} I d$.
${ }^{180} I d$.
${ }^{181} I d$. 
born and, finally, in being a responsible father. ${ }^{182}$ In short, the NPP states that the active cooperation and participation of men is vital for ensuring programme acceptance. Further, over $97 \%$ of sterilizations are tubectomies and this manifestation of gender imbalance needs to be corrected. ${ }^{183}$ The special needs of men include re-popularizing vasectomies, in particular no-scalpel vasectomy as a safe and simple procedure, focusing on men in the information and education campaigns to promote the small family norm. ${ }^{184}$

However, the NPP has missed an opportunity to strengthen the government's approach with regards to male responsibility and reproductive rights. The Cairo Conference stated that male responsibility includes supporting gender equality, adjuring violence against women, and supporting women's reproductive and sexual health and rights. ${ }^{185}$ Conversely, under the NPP, male responsibility is still viewed as the need to encourage men to use condoms or take a greater role in contraception. ${ }^{186}$ There is no further responsibility placed upon the man in terms of reproductive choices. Indian women's bodies, rather than male bodies, become problematic, and are clearly linked "to gender domination" in India. These norms are imposed upon women by the Indian government. Those affected are often the impoverished rural women who have no choice; she is at the mercy of the State.

CEDAW mentions the positive links between compulsory sterilization and abortion wich affects women's physical and mental health, and infringement on their right to decide on

\footnotetext{
${ }^{182} I d$.

${ }^{183}$ National Population Policy, supra note 157.

${ }^{184}$ Id.

${ }^{185}$ Sen, supra note 166.

${ }^{186} \mathrm{Id}$.
} 
the number and spacing of their children. ${ }^{187}$ Despite India's ratification of the Convention, at the State and local levels of government, India is failing to adhere to these principles by limiting women's reproductive choice through policies such as the National Population Policy, which sustains ground level coercion because of the incentives provided by the central government. The NPP portrays the poor Indian woman as being the problem. This policy prevents Indian women from making safe reproductive/sexual choices- the right of a woman to chose when to have sex and when not to, when to have children and how far apart to have them, "when to use contraception and what method". It is this specific right to choose with regards to contraceptive methods that enables women to treat and control their bodily practices thus permitting an environment conducive to safer reproductive choices.

Similarly, when we examine health care issues in African countries as well, it is apparent that, often, States are forced to forfeit social needs to meet macroeconomic goals. ${ }^{188}$

The failure to prioritize public health denies its significance in promoting long-term economic growth. As the WHO Commission on Macroeconomics and Health recently concluded, health is more than an

\footnotetext{
${ }^{187}$ Successful legal strategies for addressing VAW and recommendations to governments Issues brief prepared by: Center for Reproductive Rights http://72.14.207.104/search?q=cache:NCRBVpM0ZvgJ:www.un.org/womenwatch/daw/egm/vaw-gp2005/docs/background/centerreprorights.paper.pdf + cedaw + and + sterilization + and + abortion\&hl $=e n$ (visited 11/10/05)
}

${ }^{188}$ Ann Louise-Colgan, "Hazardous to Health: The World Bank and IMF in Africa Africa Action Position Paper." http://www.africaaction.org/action/sap0204.htm (visited: March 25, 2006). 
outcome of development; it is a crucial means to achieving development. $^{189}$

Clogan argues that in order to address this crisis, it is necessary to undertake the structural factors that stimulate it. The World Bank and IMF must acknowledge their responsibility for the destructive brunt that their policies have had on various Third World States. $^{190}$

\section{Conclusion}

In order to realize effective reproductive/sexual rights programmes within India, the policies must direct domestic governments (at all levels) to adhere to international instruments that protect and empower women with their reproductive choices. States should be pressured to adhere to their political commitments to both Cairo and Beijing instruments with respect to women's reproductive rights. This would enable a level of successful reproductive choices, policies should positively target the poor women at all levels of government, without providing incentives/disincentives which is a problem within the current NPP 2000. Reproductive health is an "umbrella" concept consisting of several distinct, yet related issues such as abortion, sexuality, maternal mortality, etc. Sexuality, abortion and male involvement are very important and these three are most often neglected when examining reproductive health issues in India.

Women's groups and health organizations in India perceive advocacy as one concrete way to hold governments accountable to international commitments made at the Cairo and Beijing Conferences. Advocacy initiatives and groups have managed to change

\footnotetext{
${ }^{189}$ For the final report of the WHO Commission on Macroeconomics and Health, see the section on the WHO website at http://www.who.int/cmhreport

${ }^{190}$ Colgan, supra note 188 .
} 
policies in the field of reproductive health, both at national and international levels. Advocacy has also been critical in shifting the focus of the health programmes from a population control approach to addressing rights development.

As well, further attention needs to be focused on changing power relations in families and societies. In the current climate, reproductive health has been reduced to a medicaltechnical problem. What is missing are the underlying social factors - gender and sexual relations, decision-making, power, choices and lack of choices, access to basic needs - all of which determine reproductive health status. Social factors need to be seen as central to the concept of reproductive health issues, both to improve their own health and to improve the health of their partners. In most cases male decision-making often determines women's health status.

This Chapter examined women's reproductive human rights and how they are applied at the national and international levels. Special attention was placed on the Cairo Programme of Action and the Beijing Declaration and Programme of Action. I looked at how the National Population Policy 2000 is discriminatory against Indian women.

The next chapter examines the case study of RUWSEC and how they have been successful in adhering to the International Conference on Population and Development policies. The Chapter focuses on the opinions of the Dalit community members who participated in my interviews. They have attended RUWSEC's reproductive and sexual rights training. The themes already addressed with regards to International instruments and population policy will also be discussed in Chapter Five. 


\section{Chapter Five}

\section{Evaluating Gender Equity, Reproductive and Sexual Rights: A Case Study of RUWSEC}

The previous Chapter outlined the international instruments which protect women's reproductive and sexual rights, and the impacts of the National Population Policy 2000 on Indian women. This chapter presents primary data from Chengalpattu, Tamil Nadu, South India in the form of a case study of a women's non-governmental organization to evaluate the claims made by the advocates and critics of women's reproductive and sexual human rights. Section I provides contextual material to providing the background for the case study and how RUWSEC functions. Section II summarizes the research methods employed in the field, including a discussion of the impact RUWSEC has had on the lives of its members. The final section of this chapter examines the research findings concerning the non-governmental organization. I look at the role of civil society in the struggle for reproductive and sexual rights advocacy in the Third World. The next chapter analyzes this case study in relation to the theoretical framework outlined in Chapters Three and Four, thus exploring the central argument of this thesis and proposing recommendations.

\section{The Context}

The following section presents an overview of how RUWSEC operates, concentrating on three key areas: a) the political and historical situations in the State of Tamil Nadu; b) the interaction of caste and class hierarchies in Tamil Nadu; and finally c) the social construction of gender in rural areas of the State. Some of the barriers to the 
implementation of adequate reproductive health care for the poor, lower caste and minority women in rural Tamil Nadu are highlighted below.

\section{Historical Context ${ }^{191}$}

The Dravida Nadu from which the current Tamil Nadu was created, comprised of various kingdoms: Pallava, the Chera, the Chola, the Pandya, the Chalukya and the Vijayanagara. The great Tamil Sangams had thrived (two Sangams-groups) were established prior the Christian era and the third flourished during 100 and $250 \mathrm{CE}^{192}$

The Pandyan sovereignty reaches far back as early Sixth Century CE; the current city of Madurai was established by the first Pandyan King Kulasekara. ${ }^{193}$ The Pandyas were renowned for their trade and education and ruled the contemporary districts of Madurai, Tirunelveli, and even parts of South Kerala. The Pandyas were trading associates of Greece and Rome and were very influential despite the fact that they were conquered during various stages by the Pallavas and Cholas. ${ }^{194}$

\section{Fourth to Ninth Century}

Between First and Fourth century BC the Cholas controlled Tamil Nadu. ${ }^{195}$ The first and the most legendary king of this epoch was Karikalan, who constructed the kallanai (kall stone, anai - bund), a dam across the river Cauvery, which is deemed to be an

\footnotetext{
${ }^{191}$ Due to the scope of this thesis, I shall try to briefly summarize the main historical events. India has a rich historical background. I only mention the major historical events pertaining to Tamil Nadu, India.

${ }^{192}$ N. Surahamanian, The History of Tamil Nadu (Madurai, Tamil Nadu: Vaigai Achagam, 1972) at 12-28.

${ }^{193}$ Id. 13.

${ }^{194} \mathrm{Id}$.

${ }^{195}$ Id., 29.
} 
engineering phenomenon for that era. The Cholas reigned what is known as modern day cities of Thanjavur and Tiruchirapalli districts and they exceeded in military conquests. ${ }^{196}$

Throughout the later half of fourth century AD, Pallavas known for their great temple constructions materialized into status where they conquered and reigned over the South for almost 400 years. ${ }^{197}$ They triumphed over a large section of Tamil Nadu where Kanchipuram (the current day Chengalpattu area) was their foundation.

In the sixth century they conquered the Cholas and controlled areas as far as Ceylon (Sri Lanka). Among the utmost Pallava monarchs were Mahendravarman-l along with his son Narasimhavarman. ${ }^{198}$ During this era, Dravidian architecture accomplished its quintessence during the Pallava dynasty. Aparajitha was the last Pallava King to rule this region until he was toppled by Aditya Chola near the end of the ninth century $\mathrm{CE} .{ }^{199}$

\section{Ninth to Thirteenth Century}

The Cholas re-ascended to supremacy by Ninth century CE. ${ }^{200}$ The reign of Rajaraja Chola and his son Rajendra Chola, began the rise to prominence of the Cholas became a prominent dynasty in South India. Their kingdom extended to far outlying areas of central India, Orissa and even constituted West Bengal. Rajaraja Chola subjugated the eastern Chalukya Empire, and soon after conquered the Cheras, and appropriated

\footnotetext{
${ }^{196} \mathrm{Id}$.

${ }^{197}$ Id., 12-13

${ }^{198} \mathrm{Id}$

${ }^{199} \mathrm{Id}$

${ }^{200}$ Id., 48, 54.
} 
fractions of Ceylon by beating the Pandyas. ${ }^{201}$ With the aid of his fleet of ships, Rajendra Chola exceeded his dynasty in Tamil Nadu by conquering the islands of Andaman, Nicobar, Lakshadweep, Sumatra, Java, Malaya and even the islands of Pegu. Rajendra Chola later conquered the king of Bihar and Bengal, Mahipala, and in order to memorialize his conquest he constructed a new capital called "Gangaikonda Cholapuram." ${ }^{202}$ Only around the thirteenth century did the supremacy of the Cholas greatly decrease.

\section{Fourteenth Century}

As the Cholas declined in power, in the early fourteenth century, the Pandyas ascended to dominance yet again. In 1316, the Cholas were soon subjugated by the Muslim Khilji, who invaded from the North. ${ }^{203}$ The city of Madurai was raided and was entirely ruined. These incursions greatly diluted both the Cholas and Pandyas and consequently led to the establishment of the Bahmani Kingdom. ${ }^{204}$

This fourteenth century incursion resulted in a retaliatory response from the Hindus, who assembled to construct a strong new sovereignty, called the Vijayanagara Empire. ${ }^{205}$ It engaged all control of Cholas and other local Hindu rulers in order to ensure that the Muslims were aware of the Hindu dominance. Soon governors were established called Nayaks, were established, and they were in charge of ruling the diverse territories of the

\footnotetext{
${ }^{201} I d$

${ }^{202} I d$

${ }^{203}$ Id, 164

${ }^{204} \mathrm{Id}$

${ }^{205} \mathrm{Id}$
} 
kingdom. The Vijayanagar Empire was the most affluent empire in the South with Hampi as its capital. ${ }^{206}$

However by 1564 , during the battle of Talikota, the kingdom was defeated by the Deccan Sultans. The kingdom was divided into several components where the Nayaks continued to rule. ${ }^{207}$ Under the Nayaks, the Tamil Country was peaceful and flourished. Amongst the most famous Nayaks were those from Madurai and Thanjavur. These Nayaks were responsible for the renovation of some of the oldest temples in the nation. ${ }^{208}$ The Cheras monarchy embraced what is known as the modern State of Kerala and elements of the Malabar. ${ }^{209}$ Their proximity to the sea gave them a great advantage which aided them with trade, especially with the Romans. This small region maintained its independence even from the Muslims, however, that soon changed once the British conquered India. ${ }^{210}$

\section{$\underline{\text { Seventeenth Century }}$}

When the British East India Company was established in 1639 in Madras, a new period unfolded in the history of Tamil Nadu. ${ }^{211}$ The British gained administrative control over Tamil Nadu, due to ongoing disputes amongst the provincial rulers. Eventually the entire Tamil Nadu and most of South India came under British rule. ${ }^{212}$ During their reign, most of Southern India was incorporated into the district called the Madras Presidency.

\footnotetext{
${ }^{206}$ Id

${ }^{207}$ Id, 146.

${ }^{208}$ Id.

${ }^{209}$ Id., 29, 271

${ }^{210}$ Id.

${ }^{211} \mathrm{http}: / \mathrm{www} . \mathrm{mdx}$. ac.uk/www/study/Localtim.htm\#1600 (visited: 02 January 2005)

212 Id.
} 
Tamil Nadu had its share of Chieftains or "Poligars" who fought the British East India Company while it was laying out its designs in bringing entire region under its rule, chief among them were Veerapandya Kattabomman, Maruthus and Pulithevan ${ }^{213}$

\section{Twentieth Century}

When India became independent in 1947, Madras Presidency became Madras State, comprising Tamil Nadu, coastal Andhra Pradesh, northern Kerala, and the Southwest coast of Karnataka. ${ }^{214}$ In 1953 Madras State was split into two States: Andhra Pradesh, encompassing the northern Telugu speaking areas, and Madras State, embracing the Southern Tamil-speaking areas. Under the States Reorganisation Act, 1956, Madras State lost its western coastal districts to the States of Kerala and Mysore. ${ }^{215}$ In 1968, Madras State adopted a new name - Tamil Nadu. The capital city Madras was renamed Chennai in $1996 .{ }^{216}$

\section{Political Context}

In most of South India and the State of Tamil Nadu, regional politics is very important. Tamil nationalism and "Dravidian" politics have dominated this region for most of this century. ${ }^{217}$ Many of the political parties in Tamil Nadu have come to power through a combination of promoting Tamil nationalism and populist promises as well as through the personal popularity of several former movie stars and other key players in the Tamil

${ }^{213}$ http://www.masterliness.com/a/Tamil.Nadu.htm (visited: 03 February 2005)

${ }^{214} \mathrm{Id}$.

${ }^{215} \mathrm{Id}$

${ }^{216} \mathrm{Id}$

${ }^{217}$ Mary Hancock, "Hindu culture for an Indian nation: gender, politics, and elite identity in urban South India," American Ethnologist, vol. 22, no. 4, 1995. 
film industry that have eventually become either the party leaders or spokespersons. The current Chief Minister, Jayalalitha of the All India Anna Dravida Munnetra Kazhagam $\left(\right.$ AIA-DMK) ${ }^{218}$ party, is also a former Tamil film star.

In the rural areas, however, both politicians and governments are judged by what they deliver in terms of infrastructure, for example, electricity, improved roads, or housing. Corruption and fraud is widespread in Tamil Nadu politics. ${ }^{219}$ It is often the poorer Tamil Nadu citizenry that suffer by lacking economic power. They are unable to persuade/pressure local government officials to assist them in getting the essential elements of daily living that most in First World countries take for granted including essential services such as electricity. During my field research in the villages of Tamil Nadu, I witnessed frequent power outages. Anil K Rajvanshi, director of Nimbkar Agriculture Research Institute States, "it is a matter of shame for all of us that even 56 years after independence, $63 \%$ of all rural households in India do not have electricity and use kerosene for lighting. Even for those rural areas, which are electrified, there is a tremendous shortage of power supply. Thus it is not uncommon for these areas to have 10-15 hours of blackouts and brownouts every day. $" 220$

\footnotetext{
${ }^{218}$ A.I.A.D.M.K. was founded by the Matinee idol M.G.Ramachandran famous cinema actor in South India in the year 1972. After breaking away from (Dravida Munnetra Kazhagam)DMK, MGR started a new political outfit only to challenge the DMK President M. Karunanidhi. He called his party as Anna D.M.K.The parting away of MGR from DMK had an impact on the ruling DMK. Became MGR was described by people as friend of the poor (YEZHAI PANGALAN). Even carefully he had chosen the character depicting him as poor's, friend in Tamil films. "KALKI" the famous tamil weekly wrote an editorial 'Test for the Truth' (SATHIYA SODHANAI) to narrate MGR's expulsion from DMK. http://aiadmk.8k.com/ (visited 12/11/2004)

${ }_{219} \mathrm{http}: / / \mathrm{www}$.hinduonnet.com/thehindu/2001/07/18/stories/04182236.htm (visited: 12/10/2004)

${ }^{220} \mathrm{http}: / /$ pune.sancharnet.in/nariphaltan/ruralelec.htm (visited: 10/10/2004)
} 
Two consequences of the historical and political milieu in rural Tamil Nadu have been, first, that the rural areas are often neglected due to government focus on urban-based populism on the part of the State government. There is a reduction in social welfare programmes. Secondly, rural women often bear the burden of the State government's focus on the urban issues. One of the consequences for Dalit women from rural communities is that they are more likely to be forced into taking extreme measures such as sterilization to address their reproductive needs.

\section{Caste/Class and Community}

A cultural nationalism framed in terms of the Dravidian linguistic and ethic identity of the Southern populations has been a dominant element of political and social life since the early $20^{\text {th }}$ century. Proponents of Dravidianism defined their identity in opposition to that of northern IndoAryan populations and that of Tamil Brahmins, who were regarded as descendants of the early Aryan conquerors of the Southern populations. ${ }^{221}$

In Tamil Nadu, both social and political divisions are based on caste superimposed by class between the Tamil/Dravidian lower caste majority, and the Brahmin religious elite. Although the Brahmin remain part of the social elite, known as the "dominant caste" or "forward community", Hancock States that Brahmins in Southern India are a "political marginality' ${ }^{222}$ The other high-status castes of landowners/cultivators dominate the rural areas. $^{223}$ Similarly, according to Kapadia, there is growing evidence of social segmentation based on caste, religion and ethnicity which remains a strong factor among non-Brahmin Tamils. In rural communities especially, different caste and religious

\footnotetext{
${ }^{221}$ Hancock, supra note 217 at 908.

222 Id., 912.

${ }^{223}$ Karin Kapadia, Siva and Her Sisters: Gender, Caste, and Class in Rural South India (West view Press: Boulder), 1995.
} 
communities reside in distinct areas and mostly interact inside their own respective villages. Minority groups in Tamil Nadu, including the Muslims, Christians, and aboriginal peoples ("tribals") maintain their own separate identities through language, dress and customs aside from the Tamil majority. ${ }^{224}$ The women of "scheduled castes" (Dalit) or "backward castes" are those who mainly work in the fields. ${ }^{225}$ Most of the RUWSEC women interviewed for this study belong to the Dalit community.

\section{Gender}

In the State of Tamil Nadu, gender interacts with many factors such as caste, religion, class and locality. However, politicians often echo the generalization of Indian womanhood; they are often described as "patient, pure, courageous, and selfsacrificing." ${ }^{226}$ Traditionally, in order to illustrate sacrifice, the Indian woman often eats last after all the male family members and guests have been fed. Karin Kapadia comments that lower caste women in rural Tamil Nadu also reflect this 'self-sacrifice'. However; this concept of 'sacrifice' is not relevant in terms of the Tamil man. ${ }^{227}$ The female identity which is deeply rooted within rural Tamil women is one form of gender based oppression that exists within the milieu of the lives of these women. In order to overcome such systemic subjugation, some Dalit women have established innovative methods to circumvent these constraints imposed upon them by Tamil society, rather than directly confronting them. For example, women RUWSEC staff members demanded that

\footnotetext{
${ }^{224}$ Id.

${ }^{225}$ Joan P Mencher, "Women's work and Poverty: Women's Contribution to Household Maintenance in South India," in Daisy Dwyer and Judith Bruce, eds., A Home Divided: women and Income in the Third World, (Standford University Press: Standford), 1988.

${ }^{226}$ Hancock, supra note 217 at 911 .

${ }^{227}$ Kapadia, supra note, 223 at 41.
} 
men work with them in their communities thereby enabling the men within the communities to better comprehend the issues pertaining to gender-based discrimination (together with caste and class discrimination). Prior to these collaborative efforts, RUWSEC staff recount an increase in conflicts between men and women in the local villages. In some specific cases, the spouses of the staff members began to oppose the work that their wives conducted because their work did not reflect the prevailing gender norms about 'appropriate' Tamil female behaviours. The women had come to the conclusion that it was important that both men and women cooperate because "genderequity was no longer exclusive to women's issues alone."

\section{The Organization}

Comparing Rural women's Social Education Centre (RUWSEC)'s programmes to the goals and standards set out in the Beijing Platform for Action's section on health; RUWSEC appears to be very well on track. In terms of objectives, the reproductive health service programme aims to be affordable, accessible, comprehensive and sensitive to gender-issues. According on feedback from the community, it is achieving its objectives in practice. Realizing that a focus on married women of child-bearing age alone will not address all of the health problems, the programme has expanded to include single women, older women, youth and men, in an attempt to meet the reproductive health needs of the whole community. RUWSEC's in-depth planning approach is shown by the understanding of the different needs of youth; that the "youth" category is not monolithic but comprises both married and unmarried young people, those in school, or working in the labor force and those working at household level. ${ }^{228}$

The Rural women's Social Education Centre (RUWSEC) was founded in 1981.

Its work is mainly carried out in villages of Tirupporur and Tirukazhukundram which are sub-districts of Chengalpattu Taluk in Kanchipuram district of Tamil Nadu, South India.

${ }^{228} \mathrm{http}: / /$ www.hsph.harvard.edu/Organizations/healthnet/SAsia/suchana/1028/rh087.html (visited: $09 / 08 / 2005)$ 
Many of the hamlets in this region are predominately composed of the Dalit communities. The vast majority live in poverty. Although most of the people are farmers, many of them do not own any land ${ }^{229}$. RUWSEC staff informed me that the founding members of the organization were a team of 13 women, many of whom were from the villages surrounding where RUWSEC had conducted their work and these women had previously been the literacy teachers with the National Adult Education Programme. women were interested in spreading the message that women need to gain greater control over their bodies and their sexual and reproductive functions, and thereby making decisions that were beneficial to them overall.

RUWSEC staff members indicated to me that achieving women's well being through women's empowerment has been the raison d'etre for their organization. The organization's objective is to assert Dalit women in overcoming the marginality biases that they face on a daily basis due to their caste. RUWSEC focuses its work on supplying needed leadership skills thereby enabling Dalit women with the opportunity to constructively change their circumstances and daily lives. The organization "seeks to challenge class, caste as well as gender-based subordination and discrimination which result in a denial of equal opportunities to health and well being." 230

The organization focuses on the following activities in order to meet their objectives ${ }^{231}$ :

- Community based health education and health promotion

- Community based reproductive health care for women

- Gender training of women

\footnotetext{
${ }^{229}$ Please refer to interview section of Appendix for further information.

${ }^{230}$ RUWSEC Anonymous \# 1 (November 13, 2003). Personal Interview.

${ }^{231}$ Due to the scope of this chapter, I will briefly explain the aforementioned RUWSEC activities, but I will place more emphasis on the community based reproductive health care programmes offered by RUWSEC for both women and men in their respective villages.
} 
- Mobilizing women to form women's groups

- Life skills education for adolescent boys and girls

- Gender and reproductive health programme for men

- Campaigns

- Publications of popular education material and training manuals on gender and health issues

- Training support for grassroots NGOs, mainly on working men, women and with adolescents on gender and reproductive health, and for the prevention of gender-based violence

- Community based and participatory research on reproductive and sexual health issues from a gendered perspective

RUWSEC staff members attribute their success in promoting reproductive health to the establishment of close relationships within these villages. One of the staff members informed me that prior to RUWSEC staff initially promoting community based reproductive health education and training, they assisted the local villagers with clarity issues such as dealing with electricity problems water issues scarcity. By helping the local Dalit community to overcome obstacles, RUWSEC was able to establish a close bond and connection, and many more women from neighbouring villages began to participate in such community based educational programmes and were willing to endorse and put into practice these skills in their daily lives. ${ }^{232}$ RUWSEC staff found it much easier to train local women as "Community Health Workers," and these women in turn helped mobilize core groups of women as informal leaders in their respective villages. These women's organizations are commonly known as sangams [associations]. Many of these community leaders comprised of both the highly educated and women who have only completed grade five. These women are trained to help motivate the respective villagers, and the programme comprises of single women, older women, youth and men to meet the reproductive health needs of the entire community. By closely

\footnotetext{
${ }^{232}$ RUWSEC Anonymous \#5 (November 13, 2003). Personal Interview.
} 
collaborating within these communities, RUWSEC has recorded success. ${ }^{233}$ RUWSEC programmes often reflect the needs articulated by the Dalit communities. For example, special campaigns are often launched based on needs addressed by the respective Dalit communities. RUWSEC trained staff members have led campaigns such as Prevention and Treatment of Sexually Transmitted Diseases, and Action against Violence against women. These campaigns primarily focus on education, but may also outline these issues at health camps, exhibitions, community meetings, etc. This strategy of providing leadership training to local village women has enabled these participants in becoming largely self-sustaining. RUWSEC only supplies some assistance of resource materials and technical support, when and if required, for any specific undertaking. These sangams are adequately empowered and are capable of executing their daily tasks without too much assistance from RUWSEC.

RUWSEC soon began expanding its activities in order to address the needs of other target groups, such as single adolescent girls. This group because they are often considered either too young or old to be participants in such programmes and are often ignored when promoting various educational and intervention programmes. Female children between the ages of 11-18 were mostly illiterate and unexposed to reality outside of the household. RUWSEC aimed to rectify this marginalization within these communities. To address this problem, the Magalir Chudar Kalvi scheme, an education and empowerment programme focused on girls, was started in December 1990. This programme focused on

\footnotetext{
${ }^{233}$ I define RUWSEC as being successful because its programmes incorporate the goals of the Cairo and Beijing conferences. For example, it incorporates a holistic approach when dealing with reproductive and sexual rights training by incorporating men within the process.
} 
teaching these girls better literacy skills as well as education about their bodies, sexuality and responsibility, contraception and gender relations.

This programme consisted of weekly workshops where these girls gained leadership skills training, which focused on areas such as public speaking, group functioning, and decision making, taking action on specific local issues and role-playing to create awareness. These workshops endeavored to educate these girls about the environment outside of the village life - including informing them on panchayats (local authority), State structure and electoral process and India, thus enabling them to function as effective citizens to partake in the democratic process.

RUWSEC has also set up an Education Programme for Young Factory Workers predominantly focusing its efforts towards the newly employed young women in 1996. Due to the changing employment structure of the communities, many more young women are employed in nearby small-scale industries. Often the majority of these young women are illiterate, and for the majority of them, it is often the first time in their lives that they are spending extensive time outside their respective villages without adult supervision. These women began to exercise their sexual rights by participating in high risk sexual activities (coerced or otherwise, unprotected in all instances). In many cases this often led to unwanted pregnancies among unmarried adolescents which soon emerged as a big problem amongst the villages. By setting up the factory education reproductive and sexual rights programme, RUWSEC has targeted those women who are often marginalized by society. 
One of the workshops that I was privileged to attend during my field visit was for newly married couples. This workshop focused on marriage and sexuality in marriage, gender relations within marriage, and assertiveness within a joint family context. The workshop was attended by the couples. In this instance, couples were separated by gender. All the men had to go into another room while all the young women were in my room. Here each respective group was asked to draw out the male and female anatomy. They were also asked what each sex expected from marriage in terms of roles. Finally the couples were brought into one room where they were asked to compare their answers. What I found extremely interesting was that these young men were much more open to, and seemed much more versed, with the non-traditional roles of their wives. When I asked one of the RUWSEC facilitators at the end of the workshops why they were more open receptive of the non-traditional roles of their wives, the RUWSEC facilitator stated that many of the young men had already undergone RUWSEC's Education Programme on Sexuality and Reproductive Health for Youth training throughout their primary schools. They were much more receptive of the non-traditional roles of their new partners. These young women were much more assertive in addressing their issues especially pertaining to their gender roles. They were not timid and were very vocal despite the fact that their spouses were sitting right next to them. This could be partially attributed to the fact that most of these young women had undergone the education and empowerment programme provided by RUWSEC as young girls growing up in neighbouring villages.

Similarly RUWSEC began working closely with young adolescent boys between the ages of (11-18) because they have so far remained on the side-lines of its programmes. For a majority of these young boys who will not be pursuing a higher education, they often 
worry about issues of career and employment. RUWSEC staff members informed me that unemployment might potentially lead productive male youth to get involved in anti-social behaviors which could eventually be self destructive. In 1996 RUWSEC established a youth centre, in a large village, where young boys had the opportunity to seek educational assistance along with their school examinations and various career choices. Both sex education and health care counseling are available for these young boys. In addition, the youth centre conducts workshops on gender sensitization while encouraging equal gender relations within marriages, sexuality, and responsible and safe sexual behvaiours.

It became apparent that the area of reproductive decision making should not only empower women to make informed decisions, what was lacking in RUWSEC's training was that the male partners of these women who have undergone various training were unfamiliar and ignorant of the issues surrounding positive reproductive and sexual decisions. RUWSEC noticed an increase in marital conflict, and in some cases the male partners were actually physically abusive towards women.

In order to overcome such conflicts, RUWSEC, in 1993 established contact with two local men's groups - Social Development Trust (SDT) and Social Education for Development (SED) - in which husbands and male partners of RUWSEC's female health workers soon became actively involved. According to RUWSEC field staff, "SDT works effectively with men in 20 villages where RUWSEC has already been vigorous in their efforts of promoting adequate sexual and reproductive programmes. SED carries out workshops in villages, tries to accomplish two community meetings a month in each of the 20 hamlets, one for unmarried/adolescent youth and the other for young, married 
men." 234 Currently, this project is now inclusive in over 50 villages, and still is in collaboration with SDT. The workshops include topics related to body awareness and sexuality, sexually transmitted diseases and AIDS, common reproductive health problems of men and women, and causes and consequences of male violence against women.

\section{Programme themes}

- Male and female reproductive systems

- Pregnancy and childbirth

- Birth control

- STDs and HIV/AIDS

- Gender relations

- Gender relations within marriage

- Violence against women

- Sexuality and what shapes sexual behaviour

- Expectation from sexual relations and marital conflicts arising from differences (as currently perceived by the men) in sexual needs of the husband and the wife

- Causes and consequences of extra-marital sexual relationships

- Working towards a healthy sexuality.

Consequently, this has contributed to a better comprehension of the interaction between men and women and their reproductive and sexual functions. RUWSEC's extensive experience dealing with women's issues greatly impacts the men's programme, and they were able to utilize the constructive feedback they continue to receive from the male participants in order to identify and overcome some of the challenges faced in the women's programmes.

The introduction of the gender and reproductive health programme for men has not only provided the men with the needed education, but most importantly it has presented them with a new sense of awareness. Subsequently, the male participants are more willing to request treatment for their health problems which often includes reproductive and sexual

${ }^{234}$ RUWSEC Anonymous staff\# 3( November 13, 2003). 
health problems. RUWSEC staff believes that this is a good step in a positive direction for both the male and female participants of undergoing the health programme for men, these men feel comfortable in approaching the male health workers and/or the trainers of SDT with any sexually and reproductive health matters. Those who seek health assistance are promptly referred to attend RUWSEC's reproductive health clinic. Despite the slow changes in the male attitude towards visiting the health clinic, RUWSEC staff deem that the percentage of men who actually attend the clinic in order to report reproductive health problems and sexual transmitted infections/diseases to be well below the average. For example, female participant \# 3 from Karumarappakkam, whom I interviewed, informed me that "her husband feels less comfortable in visiting the clinic, because both full-time doctors are female." This does not necessarily reflect the attitude of all the men within these 50 villages who have participated in the gender and reproductive health programme for men. ${ }^{235}$

Over the years, RUWSEC began to notice that the existing health services available to both men and women were becoming economically unfeasible and very limiting. In addition, the public health system was not oriented towards promoting safe reproductive and sexual health. Often the villagers were very vocal in addressing their frustration as to why they were not able to access reproductive health services at a minimal cost. The villagers complained about the uncaring and inadequate public health services because it was very limiting, especially when addressing women's reproductive/sexual health matters. RUWSEC knew that there was a demand for a clinic that would provide good reproductive/sexual health care at nominal costs. Subsequently, with financial assistance

\footnotetext{
${ }^{235}$ Female Participant \# 3, Village Karumarappakkam, Anonymous. (November 15, 2003).
} 
from the MacArthur Foundation, USA, RUWSEC undertook a new step in providing quality health services by establishing its clinic on June 8, 1995 in Chengalpattu. In order to meet these new employment challenges, RUWSEC's health workers were chosen and trained as record keeper, receptionist, counselor/health educator, pharmacist/cashier and laboratory assistant.

Initially the clinic only planned to provide out-patient services, where they were able to include diagnosis and treatment for men and women's reproductive health problems which includes STDs, pregnancy, post-partum care and birth control. As well, they wanted to make available on site counseling and information on various methods of birth control methods such as oral pills, IUDs and diaphragms. The clinic had an average of 500 clients per month, clients among which were women and children, but only a small number of men sought advice and treatment, mainly for STDs; almost 40 percent of the women seek treatment for RTIs. During April 2000-March 2001, RUWSEC medical staff reported that "there were 6686 clients who attended the outpatient clinic among which 1783 were male and 4903 were female clients." The clinic had also been transmitted to a new building located in the village of Karumarappakkam which is 20 kilometers from Chengalpattu. RUWSEC also admits and treats in-patients during the months of April to December 2000, RUWSEC staff members reported that "that there was over 274 compared to 569 in the last year, 138 were deliveries, 114 underwent post-partum sterilization, and 20 IUD insertions, and only 2 abortions were performed. $" 236$

${ }^{236}$ RUWSEC Medical Staff \# 3, Anonymous (November 17, 2003) 
One of the important features of the clinic is the clinical laboratory, which provides testing facilities for both clients who come to the clinic as well for those who have been referred to the laboratory by other doctors in the neighbouring villages. Soon the laboratory's reputation was well known, consequently, the referrals from adjacent areas steadily increased. During the months of April 2000-March 2001, according to one RUWSEC lab staff member, "the lab conducted over 250 investigations per month, majority of the women came for the ANC tests."237

Another important component of the clinic's activities is the provision of health education and counseling. Upon receiving treatment instructions from the medical professionals, one of the RUWSEC medical staff had stated to me that "the clients have meetings with the community health worker/health educator in order to better comprehend the problem, cause, self-care, nature of treatment recommended and preventative measures. ${ }^{9238}$ In addition, trained counselors are available on site to provide counseling on a variety of topics and issues. All of the health education materials are available and freely distributed throughout the villages. In addition, these clients are encouraged to attend the RUWSEC village workshops on reproductive health issues.

\section{Research Methods}

Field research for this study took place in Chengalpattu, Tamil Nadu in month of November 2003. The central objective was to evaluate the impact of RUWSEC, a grassroots women's organization, on local Dalit women's reproductive and sexual decisions. First, I wanted to study a successful, locally managed, grassroots women's organization in order to gain insight as to why they have been able to successfully

\footnotetext{
${ }^{237}$ RUWSEC Medical Staff\#5, Anonymous (November 17, 2003)

${ }^{238}$ RUWSEC Medical Staff\#2, Anonymous (November 17, 2003)
} 
promote safe reproductive and sexual health initiatives in a rural community. Data collection for this case study was carried out in rural areas where RUWSEC operates in the surrounding villages of Chengalpattu, a small rural community located about two and half hours by car inland from Madras.

At RUWSEC, one key source of information was a limited version of participant observation. This included observation of, and some degree of participation in, the RUWSEC's events and activities as well as visiting the local clinic and interviewing those who have participated in RUWSEC training. A second source of information came from my discussions with key RUWSEC staff members. There was no problem of language barrier because I speak Tamil, and my mother, who accompanied me also served as translator if my Tamil was not good enough. Third, group interviews were conducted with RUWSEC staff members ranging from field/social workers to various clinical staff. The interviews with RUWSEC staff were helpful in learning how the organization is structured and how it functions. The history of RUWSEC and its plans for the future were also topics raised during the discussions and interviews.

The data collection process was a set of in-depth interviews with RUWSEC staff which included the field staff and as the RUWSEC clinical members. ${ }^{239}$ Interview respondents were selected with the assistance of RUWSEC staff to form a purposive sample covering range of histories and experiences reflective of the organization and their programmes.

\footnotetext{
${ }^{239}$ Although some might think that this was not ideal, as it was difficult to bring members to speak critically about their organization with other staff members present. However, I made it clear that I was only present to find out how their work has helped promote safer reproductive and sexual health in the Dalit communities, not to assess their NGO. Once I made that clear, most of the RUWSEC staff felt very comfortable and spoke freely to me about their experiences working in the local communities.
} 
Among the staff members, there were both women and men of different religious communities, with a wide age range from the young to the more elderly. Some of the participants in my interviews were highly educated with graduate degrees while others had only completed a grade eight education. Interviews were conducted at the main RUWSEC office, and I requested RUWSEC staff members to provide me with quantitative information about their programmes, and their observations while directly participating and facilitating the aforementioned programmes.

\section{Findings and Discussion}

The RUSWSEC staff members along with the five Reproductive Health Services Clinic medical staff (RUWSEC doctors, nurses, social workers/counselors and hospital workers) were asked the following questions:

- What are the methods employed in achieving gender-based equity education and women's reproductive/sexual health?

- Are women comfortable speaking about their bodies when learning about responsible sex?

- What are some common reproductive health issues that women face?

- What methods have you employed in promoting contraceptive advice?

- Is there a correlation between women's literacy skills and an increase with regards to reproductive rights?

- Are men being incorporated in the reproductive/sexual education and gender sensitization training?

- What are some hurdles that RUWSEC workers face on a daily basis?

The interview technique was open-ended, allowing respondents to ask for clarification, in order to add additional information and include topics we had not proposed, but following set of guidelines about the main areas of interest. During these interviews, I asked the aforementioned questions and recorded responses. 
The majority of both RUWSEC field staff ${ }^{240}$ along with the medical staff informed me that one of the main reasons for RUWSEC's success rate, in terms of employing genderbased equity education and women's reproductive/sexual health, has been due to the fact that 'from its inception, RUWSEC has been both women-centered and community-based in its values, objectives and strategies.' As well, many of the medical staff members reiterated that RUWSEC's programmes, goals and standards mirror those set out in the Beijing Platform for Action's section on health. According to the majority of the staff, RUWSEC is on the right path. The RUWSEC staff members have stated that the 'objectives of the reproductive health service programme aims to be affordable, accessible, comprehensive and sensitive to gender-issues.' They strongly believe that this is mainly due to the fact that RUWSEC, as an organization, takes into consideration the feedback provided by the local communities.

Moreover, the RUWSEC staff have mostly suggested that success is also partly due to the fact that their reproductive/sexual rights policy is not to solely 'focus on married women of child-bearing age alone which they have come to realize does not address all of the health problems,' but instead by incorporating within its programmes single women, older women, youth and men, in an attempt to meet the reproductive health needs of the whole community." As well, a majority of the field staff have suggested that "RUWSEC's in-depth planning approach is revealed by the organization's ability to comprehend the needs of different youth; this category is not monolithic but comprises of

\footnotetext{
${ }^{240}$ The responses provided by the various participants that I have interviewed do not reflect the opinions of all of the women and men who work for, and with RUWSEC.
} 
(married and unmarried young people, those in school, or working in the labor force and those working at household level.)"

The medical staff suggested that many of the Dalit women were comfortable and open about speaking their bodies when learning about responsible sex. They suggest that this is mainly due to the fact that most of these women have attended various forms of community based health education and health promotion training as well as other community based reproductive health care for women and gender training of women throughout the years which were facilitated by the field RUWSEC staff. Consequently, one of the RUWSEC doctors suggested that "because of the education that they have received and the strong relationship that RUWSEC field workers have cultivated within these communities, it is not surprising that these women feel very comfortable and open while discussing very sensitive and intimate reproductive issues with the RUWSEC clinical staff."

The RUWSEC clinic was opened on June 8, 1995 in Chengalpattu. Both the RUWSEC staff and the medical professionals suggested that some of the common reproductive health issues that women face were "with regards to women's reproductive health problems including STDs, pregnancy, post-partum care and birth control." Other than just providing counseling and information services on birth control methods, the clinical staff members also "supply their respective clients with access to temporary methods such as oral pills, IUDs and diaphragms." The majority of clinical staff consensus suggest that about 'forty percent of the women seek treatment for reproductive tract infections (RTIs)' and the staff members attest that it is mainly due to the hard work of health workers who 
have been able to persuasively follow up and ensure that the partners of their clients are also seeking treatment. One medical staff representative stated that "the success in partner treatment is largely due to the efforts of the health workers because of their efforts this has led to a reduction of reoccurrence of infections because both partners are more and more actively protecting themselves, by undergoing and following through with prescribed course of treatment." The clinical staff advised that due to the Tamil Nadu government's positive response towards financial subsidizing in April 1996, subsequently, RUWSEC clinic expanded by constructing a well-equipped operation theatre where deliveries have been performed.

When I questioned RUWSEC field staff on whether they felt that there was a direct correlation between women's literacy skills and an increase in the demand for adequate reproductive rights; a majority of them agreed wholeheartedly that there is a definite relationship between the two. The staff suggested that RUWSEC's women-centered educational programmes have greatly empowered these Dalit women in the local villages to strongly feel that "it is a women's right to control their bodies and lives, as well they believe that women's sexual/reproductive rights are no longer subordinated vis-à-vis their male partners and these women have learned and are well aware that it is their right to demand quality reproductive health care."

When I inquired whether men were being incorporated in the reproductive/sexual education and gender sensitization training, all of the RUWSEC field staff along with the clinical staff unanimously responded that men have been receiving gender and 
reproductive health education since March 1998. According to RUWSEC staff, as of 2001 the "total number of men covered during some form of gender and reproductive training is well over 5000." One of the field staff informed me that, "the total number of condoms distributed were during this time period were 2278 , of which $70 \%$ was utilized by the men to avoid infection and conception." As well, one of the medical staff informed me that "many of the male clients who visited the clinic often praise the various documentaries and commercial movies which addressed topics related to abortions, sexually transmitted diseases, and awareness on AIDS, and finally gender violence against women."

Finally, I asked all the RUWSEC staff members who were interviewed to describe some hurdles, if any, that RUWSEC workers face on a daily basis. A large number of the field staff had informed me that despite the fact that RUWSEC has been an established organization, "not everyone in the small communities is open enough and willing to address the changes in reproductive decision-making dynamics of women and men." The staff had informed me that in some cases, it is not 'just the partners of these women who oppose the women from attending various training programmes but it is also their own immediate families who fear mainly the unknown, because traditional Tamil women do not often discuss such intimate details in a public setting.' One of the RUWSEC staff members informed me that, although this particular perception is decreasing, some young women are still very shy to gain knowledge and new insight toward their bodily functions. The staff members stated that unless this attitude changes, despite the various 
reproductive and sexual rights training provided, it will be a challenge for both RUWSEC staff and for these young women.

It was noted that, overall many more people from the surrounding communities are becoming more open to the various programmes that RUWSEC continues to provide on a daily basis within their respective villages.

One of the medical staff informed me that there are still lingering issues surrounding men's and women's roles in their personal lives. Due to various misunderstanding with regards to the roles in society and at home, there are still incidences of domestic violence, rape and other circumstances which not only endanger women's health but also hinder women's empowerment. RUWSEC staffs have worked to make community-based resources for prevention of violence against women accessible to all. The field staffs have acknowledged that it is challenging for them to address the issue surrounding domestic violence, which is not often considered as a major gender-justice and health problem by those within the communities. They have suggested that it has taken a long time for them to get most of the villages to acknowledge this as an important problem and RUWSEC staff informed me they were able to achieve some success with aid of the local village community leaders.

In the following section, I examine the answers of the ten women and men who were asked to describe their experiences with regards to the reproductive and sexual rights training provided by RUWSEC. 
contraception is a very different proposition from selling the daily loaf; programme managers have had to learn how to motivate women to become acceptors, to educate and to counsel them...Indeed, established family planning programmes...often [extend] to the farthest reaches of the society. ${ }^{241}$

The ten women and men who were interviewed were from two small villages of Karumarappakkam and Echankaranai. They were asked the following questions:

- Did you feel comfortable discussing your sexual and reproductive rights?

- What part of the RUWSEC programme do you feel directly affects your life?

- Why do you think you have had success with regards to promoting your reproductive/sexual rights? How was this possible? What steps did you take to initiate positive change with regards to your reproductive/sexual functions?

I interviewed a total of eight female and two male participants from the two aforementioned villages. When the female participants were asked whether they felt comfortable discussing their sexual and reproductive rights, majority of the respondents stated that initially they felt a bit uncomfortable. However, because of RUWSEC's training, they had participated in various gender training, life skills education for adolescent boys and girls, and the gender and reproductive health programmes; they were no longer shy to discuss some of the most intimate details of their reproductive and sexual lives.

Many of the female respondents agreed that they felt comfortable mainly due to the fact that a previous relationship had been established by RUWSEC staff and many of the female villagers. For example, participant \# 3 from Karumarappakkam stated that, "I no

\footnotetext{
${ }^{241}$ Jason L. Finkle and C. Alison McIntosh. (1994). "The New Politics of Population.”
} Population and Development Review. : 5. 
longer feel shy discussing my reproductive and sexual functions. Due to continuous community support, programmes like women's health education and health promotion, community based reproductive health care training for women and the gender training for women most of which I was privileged enough to attend, enabled and greatly encouraged me to discuss issues surrounding my reproductive and sexual rights. After attending one of the workshops, I strongly feel that I own my body, I am responsible for my body and no one else can control my body other than me."242

The responses to the question, "what part of the RUWSEC programme do you feel directly affects your life?" indicate that almost all of the women from Karumarappakkam and Echankaranai were addressing two of the aforementioned themes surrounding knowledge of the female body and controlling fertility. Because six out of the eight female participants are married, these themes were explicitly addressed throughout the interview process. Many of the married women felt that they learned great insight with regards to their body awareness, both female/male physiology/anatomy, issues concerning pregnancy, labour/childbirth, and postpartum care/complications. Data indicates that among the total women participants' the majority were interested in employing different means of family planning services.

For example, Participant \#5 from Echankaranai, stated that "I learned that the relationship with my body changes over one's lifetime and undergoes various stages. I believe RUWSEC's training has had a positive impact on the different aspects of my

\footnotetext{
${ }^{242}$ The responses provided by the various participants who I have interviewed do not reflect the opinions of all of the women and men who have undergone RUWSEC training.
} 
reproductive and sexual functions. First, I was grateful to have had the opportunity to attend the workshop dedicated for pregnancy. During this time I learned that nutrition was especially important during the prenatal period, specifically I learned that consuming foods rich in calcium, iron and protein were essential for a healthy pregnancy. As well, since I was suffering from anemia during my first pregnancy, after having attended the RUWSEC clinic, I carefully followed the suggestions provided by the medical staff for all my other pregnancies. In addition, with regards to my sexual activity, after having attended the workshop on 'community based reproductive health care for women,' I feel that it is very important to take charge of the responsibility surrounding contraception. This is why after having had my third child I had undergone sterilization surgery because my husband was not willing to undergo a vasectomy."

The respondent's answer with regards to her having undergone sterilization brings up the concerns with "end-controlled" technologies which are propagated by various population control agencies. This is mainly due to the colonial belief system where these population policies illustrate the Southern women/population as being "unfit for self-rule." Consequently, these populations are deemed untrustworthy to successfully administer control over their bodies. These policies implicitly demonstrate the North's (population policy agencies) "colonialist positioning towards addressing population policies of the South."

When participants were asked "why do you think you have had success with regards to promoting and exercising your reproductive and sexual rights," the respondents attribute 
their success to the various RUWSEC training programmes that the participants, their partners and family members have undergone. Majority of the women and men who had responded indicated that the training not only educated them of their reproductive and sexual functions and rights but also brought about attitudinal changes within themselves and how they perceive those individuals of the opposite sex. They believe that they are more open and comfortable in seeking treatment for their health problems which may include reproductive and sexual health problems of the relationship that has been created between RUWSEC and the those participants from the two villages.

The responses to the question "how was this possible; what steps did you take to initiate positive change with regards to your reproductive/sexual functions," were overwhelmingly positive. Many of the respondents provided great detail as to how they were able to make such positive changes concerning the most intimate details of their private lives.

For example, female participant \# 2 from Karumarappakkam said that she learned to take preventive measures when it came to protecting herself from having to go through the worries of unwanted pregnancies. "After having attended RUWSEC's gender and reproductive health awareness workshops for young women working, I learned that I have control over my body. I have been able to discuss this with my husband and have requested that he treat me kindly during sexual intercourse and I have also requested on a number occasions that he use condoms. For most women, prior to attending any of the RUWSEC training we have only perceived our bodies to be purely mechanical. Prior to having attended RUWSEC training, I feared denying my husband sex because I always 
believed that he would get angry and even beat me if I denied him. However, my husband has also attended the gender and reproductive health programme for men. After having attended this training my husband was more open to using condoms as well as he had received counseling for his alcoholism. My marriage and especially my sexual life are much happier. I now have complete control over my sexual and reproductive freedoms. I strongly recommend this sort of training for other women throughout Tamil Nadu."

Similarly, male participant \# 1 from Echankaranai said that "I had attended both the RUWSEC training provided to me during my primary education and recently, I had undergone the gender and reproductive health programme for men. I learned a great deal about reproductive health and reproductive functions of both men and women. I'm able to freely discuss various contraceptive methods with my wife. I feel very comfortable using a condom, and I take an active role in helping my pregnant wife with the household chores. I learned that if she carried heavy loads this could potentially lead to her having a miscarriage. I feel that our relationship has improved and I feel that has a lot to with me using the valuable knowledge that I had gained during the training. It is sad that not all men are willing to undergo such training. What I especially enjoyed about the RUWSEC training was that they were very open and at no point were they judgmental. No question seemed to shock them and a lot of the other young and old men who had attended the reproductive workshop for men felt comfortable enough to ask various questions about the female and male biological functions. Consequently, I believe this has opened up my mind; I am better able to comprehend the complexities associated with reproductive and sexual health from a female perspective." 


\section{Conclusion}

As I went through the interviews and the answers provided by both the RUWSEC staff members along with the women and men who had undergone various reproductive and sexual rights training, there were three major themes which became apparent throughout the case study process: the public/private dichotomy; shift in power dynamic between the sexes, and the control of the female/male body. As Pate man argued:

The dichotomy between the private and the public is central to almost two centuries of feminist writing and political struggle; it is ultimately, what the feminist movement is about. ${ }^{243}$

It is not surprising that the notion "the private as the personal," applies especially when addressing this particular case study. Historically, social norms and laws were gendered because they clearly defined distinction between the 'home as private,' and the 'rest of civil and political society as public. ${ }^{244}$ It is not surprising that the Indian legislation was lagging behind. In August 1997 India had pledged that CEDAW should be employed to further elaborate and provide supplementary meaning to the current Indian constitutional guarantees thus protecting the human rights of Indian women. These separate spheres have enabled feminists to focus on the constitutional protection of personal or family privacy. Tracey E. Higgs states that "feminists have begun to re-imagine privacy rights in a way that might more fully realize for women the values informing liberal privacy.

\footnotetext{
${ }^{243}$ Carole Pateman, Feminist Critiques of the Public/Private Dichotomy, in Public And Private in Social Life (S. I. Benn \& G. F. Gaus eds., 1983) at 281.

${ }^{244}$ Anita L. Allen \& Erin Mack, "How Privacy Got Its Gender," 10 North. Illinois. University Law Review.441 (1990) (discussing gendered images of privacy).

${ }^{245}$ Tracey E. Higgs, "Reviving the Public/Private Distinction in Feminist Theorizing," http://lawreview.kentlaw.edu/articles/75-3/HIggins.pdf (visited 04 February, 2005)
} 
Consequently, some liberal feminists in India have been utilizing the privacy notion in order to address arguments involving reproductive "rights" or "choice." This was certainly apparent in the interview answers provided to me.

The second theme, which was apparent throughout the case study interviews, was the shift in the power dynamics. With more women becoming educated and empowered especially pertaining to their reproductive and sexual rights, changes in social roles and norms are leading to drastic shifts in relational power in these villages. Partners now are more likely than before to be able to enter into relationships with much more equality in power, thus facilitating greater equity within a relationship. It is apparent that RUWSEC facilitated an environment conducive for such positive changes with regards to the shift in the power dynamics.

Finally, it is apparent that women and men are finally able to take control over their bodies and hence their fertility. By undergoing the various reproductive and sexual rights training, the women's bodies are no longer being fully and exclusively controlled by medicine, law and the State. Due to RUWSEC's gender-sensitization training, women are granted the necessary means in making mature, and rational reproductive decisions. Women and men who have participated in such programmes see a positive change in the modicum of control towards their reproductive and sexual choices. In this example law able to freely employ medical knowledge of women's bodies to control and limit their contraceptive practices. From the answers provided by the various participants, women are not reduced down to their reproductive functions. With RUWSEC promoting the 
goals and standards set out in the Beijing Platform for Action's section on health, the organization has made positive changes, and recorded successes because its agenda seems to be inspired by the Beijing Platform.

From my observations during my field trips, it is apparent that RUWSEC has been both women-centered and community-based, and this has been its strength in the implementation of the various projects. RUWSEC's policies clearly mirror those goals and standards set out in the Beijing Platform for Action's section on health. In terms of the reproductive health service programmes, they are affordable, accessible, comprehensive and sensitive to gender-issues. Due to the fact that RUWSEC continues to incorporate feedback from the local communities, they are able to achieve their set objectives. As well, because RUWSEC utilizes a holistic approach with regards to addressing reproductive and sexual health, it is able to target married women, single women, older women, youth and men, within these Dalit communities.

Moreover, RUWSEC has employed some ground-breaking ideas by co-operating with the men's community organizations. This programme reflects the appraisal of women's health service and also incorporates women's position (power relationships) in the home. This particular programme receives constant critical review because RUWSEC wants the programme to continually reflect the needs of the Dalit communities. RUWSEC community-based approach focusing on literacy and education enabled the organization to expand its focus towards reproductive and sexual health service to those Dalit communities. 
The question which comes to mind then is, if RUWSEC is successful within the Chengalpattu District, why has the Tamil Nadu government not incorporated this sort of NGO based sexual and reproductive education throughout the State? If such training is incorporated in Tamil Nadu, will the society accept to participate in this innovative programme, involving: reproductive and sexual rights, premarital sex, and women's right to choose and control her reproductive functions? As well, would it be easier for other women's based NGOs in the State to start training their own local women/men with regards to positive reproductive and sexual education?

This Chapter was a qualitative study based on observation, participation, and interviews. I learned about RUWSEC's collective struggles and success in the past and about some of their plans for the future. I set out to get a picture of an NGO from the point of view of the women and men who have undergone such training. I gained practical insights into the issues surrounding reproductive and sexual rights from those who resided in the two aforementioned villages in Tamil Nadu. I learned a great deal from the RUWSEC staff and especially those Dalit men and women who responded to my interview.

The next chapter looks at the overall analysis from the themes that were apparent in Chapters Three, Four and Five. The following chapter examines the relevance of civil society in the struggle for reproductive and sexual rights advocacy in the Third World. Since RUWSEC is a civil society organization, it seems that where governments like that of India, leaves a gap in governance, a civil society group like RUWSEC can fill the gap, with funding and capacity. 


\section{Chapter Six}

\section{Interpretive Analysis and Conclusion}

Advancing gender equality and equity and the empowerment of women, and the elimination of all kinds of violence against women, and ensuring women's ability to control their own fertility, are cornerstones of population and development-related programmes. ${ }^{246}$

The International Conference on Population and Development Programme of Action clearly condemned the use of "targets" in family planning programmes because the document states that such programmes would lead to coercion in order to achieve "low population goals." Among the initial countries that wanted to change their population policies in order to conform to the provisions of the Cairo Programme for Action was India. By conforming, India had agreed to ban the use of targets in its family planning programmes. However, the National Population Policy 2000 does clearly reflect the use of targets and "incentives" in order to achieve the current population goal.

Many developed nation-states along with transnational financial actors have often stressed the importance of Third World States controlling their population. It is not surprising that the discourse surrounding the sequence of events leading to globalization, often target the 'poor women from the South' and these women are illustrated as 'subjects of development.' In order to teach them 'modernity and help' them become 'liberated' and 'liberalized,' contraception has been presented as a "gift" from the global North.

\footnotetext{
${ }^{246}$ Programme of Action of the International Conference on Population and Development, Cairo Egypt, Sept. 5-13, 1994, para. 7.12, U.N. Doc. A/CONF.171/13/Rev.1 (1995) [hereinafter ICPD Programme of Action].
} 
Both the impact of globalization along with transnational actors such as the World Bank continues to negatively hinder the reproductive and sexual rights of Third World women as I outlined in Chapter three. Globalization has enabled the erosion of social welfare programmes thereby further marginalizing Third World women. States such as India have are compelled to adhere to population policies dictated by the World Bank. It is true that for Third World women their struggle mainly focuses on their communities and their fight against infant mortality, problems concerning nutrition, illiteracy, adequate health care, skill training, economic exploitation, and especially racism. However, this assumes that all Third World women are a coherent/homogenous group where they have identical interests, and moreover this argument does not take into accounts their respective class, ethnic or racial location, and caste of these women.

In contemporary feminist theory, "women" as a category, is employed by some Western feminists to portray Third World women as being a homogeneous, powerless group, often victims of a particular socioeconomic system. This thesis questions notions of cultural neo-imperialism. This is especially evident in the methods employed by population control agencies and transnational institutions in order to control population of the Third World. In order to promote and protect the reproductive and sexual rights of Third World women, the Indian government at all levels should utilize international instruments such as CEDAW and other international policies set forth in the ICPD and Beijing Platform in order to empower marginalized poor women thus enabling them the opportunity to make effective reproductive decisions. 
This chapter demonstrated how more women globally are demanding that they have direct access to reproductive heath as part of their human rights. The ongoing advocacy of contraception and sterilization in the Third World as one of the primary means of controlling population often points to the fact that "overpopulation" is the primary cause of poverty and underdevelopment. This assumption is clearly false and over simplifies such analysis. Poor Third World women are often suspicious about the contraceptive devices and drugs that are often forced upon them. Third World women feel that issues of race and class should be incorporated when discussing reproductive matters. The raceand class-based history of reproductive rights have and continue to directly affect women of colour. For these women, the notion of a "woman's right to choose" to bear children have always been arbitrated by the controlling, racist/classist State.

Chapter Four examined women's reproductive rights discourse and its application to India. The main focus surrounds the National Population Policy 2000 and how it continues to limit women's reproductive and sexual rights in India. It is due to high incidences of abuse and coercive sterilization practices in India; this does directly violate Indian women's human rights under international law. In this case the Indian government is not protecting its citizens' rights to "health, health information, physical integrity, and reproductive self-determination." 247 However, the Indian Supreme Court is making positive changes by condemning illegal and coercive sterilization practices by "ordering State governments to regulate health-care providers who perform sterilization procedures

\footnotetext{
${ }^{247}$ Statement from Nancy Northup, President, Center for Reproductive Rights Responding to India Supreme Court Decision on Country's Sterilization Practices. http://www.crlp.org/pr 05 0310india.html (visited: 04, 02, 2006)
} 
and to compensate the relatives of victims who may die from botched operations." ${ }^{248}$ This is apparent in their decision towards Shri Ramakant Rai and Health Watch U.P. and Bihar v. Union of India. ${ }^{249}$

In order to achieve women's reproductive human rights the following must be present: gender equality and women's empowerment; universal access to ensure healthy reproductive and sexual health; last but not least, policies should not be discriminatory or coercive in nature when promoting reproductive and sexual health programmes. By educating policy makers, health care providers, and ordinary citizens, in a country such as India can ensure that the highest standards are met with regards to promoting and protecting women's reproductive and sexual rights.

The Indian government at all levels should not only abide by the Cairo and Beijing commitments that they had agreed to, but also devote financial along with other resources to ensure that sexual and reproductive rights education is a mandate at all levels. Sustained advocacy by civil society organizations, will lead to awareness in poor rural communities and thereby enable greater acceptance of reproductive and sexual rights programmes and training within these communities.

Chapter Five illustrated how RUWSEC has been successful in promoting and protecting safe reproductive and sexual rights training for the Dalit women in Chengalpattu, Tamil Nadu, India because they followed the Programme of Action outlined in the ICPD. 
RUWSEC took a holistic approach towards promoting reproductive health care and training. In their case, the organization did not take a singular focus on fertility or family planning services. RUWSEC's approach to educating the Dalit community with regards to population policy explicitly incorporated reproductive rights: the right to reproductive health care and the right to reproductive self-determination. The answers provided by those who participated in the interview clearly illustrated that they practiced the right to reproductive self-determination where the majority of the participants had the right to plan one's family, the right to freedom from interference in reproductive decision-making and the right to be free from all forms of violence and coercion that affect their individual sexual or reproductive lifestyle.

If only more NGOs began to directly participate and collaborate their efforts in implementing human rights treaties that directly affect women's reproductive and sexual rights, there will be positive changes in terms of women's reproductive and sexual rights for women throughout Tamil Nadu, and India. The NGOs should speak against laws that are restrictive and discriminatory in nature. These NGOs should place pressure on all governmental levels requesting that India takes a more comprehensive approach with regards to promoting reproductive and sexual health services which should be directly in line with the ICPD Programme of Action. It appears that where governments leaves a gap in governance, a civil society group like RUWSEC can fill the gap, with funding and capacity. Civil societies are relevant in the struggle for reproductive and sexual rights advocacy in Third World States. 
Women should be provided greater access to a variety of family planning options not forced into sterilization; as well men need to be directly involved when education takes place with regards to promoting and protecting women's reproductive rights.

Moreover, health practioners in Third World countries should undergo gender sensitization training with regards to promoting adequate reproductive and sexual rights. More funding should be provided both at the national and State level with regards to providing more holistic and innovative reproductive rights programmes. In addition, pressure should be placed on international donors to focus less on family planning programmes and broaden their efforts to include promotion of reproductive and sexual health education and training. In order to achieve this, donor agencies and countries should ensure that they address the ongoing discrimination employed upon Third World women with regards to their legal, economic and social needs, and work towards pragmatic and comprehensive reproductive rights.

Reproductive and sexual rights are no longer issues which only affect the Dalit women from rural Chengalpattu, Tamil Nadu, India. These rights are very important to all women regardless of race, religion, class or caste. The focus on population numbers at the expense of human rights is counter effective laws and policies should promote women's rights-- their human rights, in a holistic and reproductive health environment.

It appears that national population debates have solely focused on reducing fertility rates but neglect to consider the impact on Third World women's reproductive rights. 
However, recent focus on reduction of fertility rate in India negatively limits Indian women's reproductive freedom. It seems that population policies have become identical with the fertility reduction goal, thus failing in ways in which population policies are being conceptualized. In order to enable safe reproductive and sexual rights choices the following must be present within a State: human rights; a holistic approach to reproductive health; advancement of women; and adequate reproductive and sexual rights education for adolescents. When addressing population policies it is appears that mainly women are the ones who must change their reproductive and sexual behaviours. Governments who impose fertility quotas and targets hope to lower birth rates. This seems to restrict women's right to reproductive self-determination and restrains women's right to bodily integrity. Such practices which often focus on women's bodies often lead to human rights infractions. It also seems that class and caste distinction play a vital role in India's population policy. It is women from these communities who compromise their reproductive rights.

Population policies often employ methods to achieve their numerical targets in India. In such cases the policy hopes to increase contraceptive prevalence, decrease maternal mortality, lower population growth rates, and finally increase the enrollment of girls in schools. This is often seen as being controversial, because targets tend to be coercive in nature, and poses limitations on women's right to decide the number and spacing of their children. 
Governments in India have used both incentives and disincentives to achieve their population goals. India's National Population Policy 2000 has an elaborate section on incentives, where cash is provided to both mothers and couples who first wait to have their first child, limit their number of children or those who undergo sterilization. It appears that incentives are lead to coerciveness. A woman's socioeconomic background greatly impacts how incentives often turn into coerciveness for her. By offering benefits or financial incentives to impoverished women creates an involuntary reproductive choice for her. The ICPD Programme of Action is very skeptical of such population policies, because such measures seem to have a negative impact on women's reproductive and sexual decisions. In such cases it appears that civil society organizations such as RUWSEC struggle for the reproductive and sexual rights advocacy in the Third World. It is apparent in this case that while the Indian government reflects a gap in governance, RUWSEC is able to successfully fill the gap through its funding and capacity building efforts.

A holistic approach should be inclusive when looking at reproductive health care. Population policies should have a comprehensive look at reproductive health.

An important characteristic of male participation is very essential. Population policies should incorporate male involvement including responsible parenthood, sexual and reproductive behaviours, prevention of STIs, etc. Reproductive health programmes should enable men the opportunity to exercise responsible reproductive health. 
It is also important to incorporate adolescents with regards to reproductive and sexual rights education. They should have adequate access to reproductive health care; education including reproductive and sexual health; child and forced marriage; unsafe abortion; unsafe delivery and childbearing; STIs, including HIV/AIDS, sexual violence, responsible male behaviours; and harmful traditional practices. Therefore, it is important to incorporate human rights, a holistic approach to reproductive health, women's advancement and adolescent reproductive and sexual health training in order to have an effective population policy which protects the reproductive and sexual rights of women. 


\section{Bibliography}

Adams. O. "International Trade in Health Services: Some Key Issues. Geneva, Switzerland: World Health Organization, 1997.

Aginam, Obijiofor, Global Health Governance: International Law and Public Health in a Divided World. Toronto: University of Toronto Press, 2005.

(2000). "Global Village, Divided World: South-North Gap and Global Health Challenges at Century's Dawn," Indiana Journal of Global Legal Studies (7): 603-27

Akhter, Farida. (Februrary 25, 2004). "Reproductive Rights: A Critique from the Realities of Bangladeshi Women." Retrieved from http://www.hsph.harvard, edu/grhf/SAsia/repro/farida.html

Allen ,Anita L. \& Erin Mack. (1990). "How Privacy Got Its Gender." North. Illinois. University Law Review (vol. 10) :441.

Baru, Rama, and Amar Jesani. (2000) "The Role of The World Bank In International Health: Renewed Commitment and Partnership." Social Science and Medicine, (vol. 50): 183-4.

Beijing Declaration and the Platform for Action, Fourth World Conference on Women, UN Doc. A/CONF.177/20 (1996), Beijing, China, September 4-15 1995 [hereinafter Beijing Declaration and Platform for Action], para. 95.

Braidotti, Rosi. (1992). "The Exile, the Nomad and the Migrant: Reflections on International Feminism." Women's Studies International Forum.(vol. 15. no.I): 78.

Center for Reproductive Rights. (November, 10, 2005). "Successful legal strategies for addressing VAW and recommendations to governments Issues brief." Retrieved from

http://72.14.207.104/search?q=cache:NCRBVpM0ZvgJ:www.un.org/womenwatc h/daw/egm/vaw-gp2005/docs/background/centerreprorights.paper.pdf + cedaw + and + sterilization + and +abortion\&hl=en

Chatterjee, Partha. (Nov. 1989). "Essay on the Family," American Ethnologist. (vol. 16. no. 4): 626.

Chinkin ,Christine. "Gender and Globalization", United Nations Chronicle Online Edition, volume XXXVII, No. 2 2000, Dept. of Public Information http://www.un.org/Pubs/chronicle/2000/issue2/0200p69.htm 
Cohen, Margot. (November 25, 2005) "After the Tsunami, A Drive to Reverse Tubal Ligations in Tamil Nadu." Retrieved from http://www.prb.org/Template.cfm?Section=PRB\&template $=/$ ContentManagement ContentDisplay.cfm\&ContentID $=12649$

Cook, Rebecca J. (1995). "Human Rights and Reproductive Self-Determination." The American University Law Review. (vol. 44. no.4): 980.

R. J. Cook, Bernard M. Dicken, and Mahmoud F. Fatahlla. Reproductive Health and Human Rights: Integrating Medicine, Ethics and Law. Oxford: Claredon Press, 2003.

Correa, Sônia and Rosalind P. Petchesky. "Reproductive and Sexual Rights: A Feminist Perspective." in Gita Sen, Adrienne Germain, and Lincoln C. Chen, eds., Population Policies Reconsidered: Health, Empowerment, and Rights. Boston: Harvard Center for Population and Development Studies; and New York: International Women's Health Coalition, 1994.

Costa, Maria Ana. "On Women's Right to Experience their Sexuality Free from Illness." Women's Health Collection/5: Women. Sexualities, Rights. Santiago, Chile: Latin American and Caribbean Women's Health Network, 2000.

Declarations and reservations by India made upon ratification, accession or succession of the CEDAW http://sim.law.uu.nl/SIM/Library/RATIF.nsf/0/3879720615d692a4c12568b90045 1c40?OpenDocument (visited:19/08/2005)

Dr. Gupta, Amit Sen. (April, 07,2003)."Population Control and Contraception Choice: Women and Health-Myth of Population Control." Retrieved from www.sochara.compdfs/pha_shamiana_sessions.pdf.

Elliot, Allison. (March 03, 2004). Caste and The God of Small Things. Fall 1997. Emory University. Retrieved from http://www.english.emory.edu/Bahri/caste.html

Fact Sheet No.22, Discrimination against Women: The Convention and the Committee,

Vienna Declaration and Programme of Action, (part I, para. 18) adopted by the World Conference on Human Rights, Vienna, 25 June 1993 (A/CONF. 157/24 (Part I), chap. III)

Fidler, David P. (1995). "The Globalization of Public Health: Emerging Infections Diseases and International Relations." Indiana Journal of Global Legal Studies. (vol.5): 8 .

Finkle, Jason L. and C. Alison McIntosh. (1994). "The New Politics of Population." Population and Development Review. :5 
Fourth World Conference on Women Beijing Declaration. (October 11, 2005). Retrieved from http://www.un.org/womenwatch/daw/beijing/platform/declar.htm

Government of Tamil Nadu, Department of Health and Family Welfare, Directorate of Family Welfare, 2002 Annual Report .Chennai, India: Government of Tamil Nadu, 2003.

Grimes, Seamus. (February 20, 2004). "Controlling Third World Population Growth: a major theme of the UN population conference in Cairo." Retrieved from

Gump,James O.(2000). "The West and the Third World: Trade, Colonialism, Dependence and Development." Journal of World History.396-398.

Hancock, Mary. (1995). "Hindu culture for an Indian nation: gender, politics, and elite identity in urban south India," American Ethnologist, (vol. 22. no. 4): 1.

Betsy. (April 9, 2003). "Population Policy: Will Coercion Come Back in Vogue? ZNET Daily Commentaries. May 1 2000." Retrieved from www.zmag.org/sustainers/content/2000-05/01 hartmann.htm - 14k - 9 Apr 2003

Health Informatics and Telemedicine. Geneva, Switzerland: World Health Organization: 1997. WHO document EB99/INF.DOC/9.

Held, David and Anthony McGrew. (Februrary 20, 2006). "Globalizaton: Entry from Oxford Campanion to Politics. Globalization in Global Transformations." Retrieved from http://www.polity.co.uk/global/globocp.htm

"Introduction" in David Held and A. McGrew in eds., Governing Globalization: Power, Authority and Global Governance. Cambridge: Cambridge Polity Press, 2002.

Higgs, Tracey E. (February 04, 2005) "Reviving the Public/Private Distinction in

Hiroshi Nakajima. (1997). "Global Health Threats and Foreign Policy." Brown Journal World Affairs. (vol.4): 320.

Hosken, Fran. "Female Genital Mutilation and Human Rights." Feminist Issues (I . 3): 11.

http://nhrc.nic.in/Declaration(Final).doc (Visited: 07/04/03)

http://www.cwgl.rutgers.edu/whr.html (visited 03/03/03)

http://www.hsph.harvard.edu/fxbcenter/V1N1mannetal.htm (visited: 06/05/05)

http://www.hsph.harvard.edu/rt21/globalism/Grimes.html-47k (visited: 03/03/03) 
http://www.unhchr.ch/html/menu6/2/fs22.htm (visited: 09/09/05)

Hurtado Aida, (1989, Summer). "Relating to Privilege: Seduction and Rejection in the Sub-ordination of White Women and Women of Color." Signs (vol.14. no. 4): 849.

Ilkkaracan, Ipek and Gülsah Seral. "Sexual Pleasure as a Woman's Human Right: Experiences from a Grassroots Training Program in Turkey." in Pinar Ilkkaracan, ed., Women and Sexuality in Muslim Societies. Istanbul: Women for Women's Human Rights Press, 2000.

India ratified The Economic Covenant on 10 Apr 1979. (for greater detail please see http:www.un.org.Depts/Treaty/final/ts2/newfiles/part_boo/iv_boo/iv_3.html. Also India ratified CEDAW DISCRIMNATION AGAINST WOMEN States that have signed, ratified, acceded or succeeded to the Convention. 8 October 1999. (Visited: 03/01/30)

International Covenant on Economic, Social and Cultural Rights (1966) 993 U.N.T.S. 3, 1976 Can. T.S.No.46, in force

Jonathan M. Mann et al. (Fall 1994)."Health and Human Rights," Health and Human Rights: An International Journal, (Vol. 1. no. 1).

Kapadia, Karin. Siva and Her Sisters: Gender, Caste, and Class in Rural South India. Westview Press: Boulder, 1995.

Kerr, Joanna. "Responding to Globalization: Can Feminists Transform Development?" in Marilyn Porter and Ellen Judd (eds.) Feminists Doing Development: A Practical Critique .New York: Zed Books, 1999.

Khanna, Renu. "Research and Intervention: Insights from Feminist Health Action in Western India," in Marilyn Porter and Ellen Judd (eds.) Feminists Doing Development: A Practical Critique. New York: Zed Books, 1999.

Lingam, Laskshmi. (1995). "Reproductive Rights and More," in Radical Journal of Health. (vol.1. no.2):136.

Long, Carolyn M. "The Advocate's Guide to Promoting Gender Equality at the World Bank." Women's Edge, Washington DC: Women's Edge Printing, April 2003.

Mahmood Mamdani. (1995).The Politics of Democratic Reform in Contemporary Uganda, 2 East African Journal of Peace and Human Rights: 94.

Mama, Amina. "Editorial." (February 22, 2006) Retrieved from Feminist Africa: Issue 4: 2005. http://www.feministafrica.org/04-2005/editorial.html 
Mencher, Joan P. "Women's work and Poverty: Women's Contribution to Household Maintenance in South India," in Daisy Dwyer and Judith Bruce, eds., $\underline{\text { A Home }}$ Divided: Women and Income in the Third World. Standford: Standford University Press. 1988.

Milligan, Kevin. "Quebec's baby Bonus: Can Public Policy Raise Fertility?" C.D. Howe Instsitute: Canada. January 24, 2002.

Mohanty, Chandra Talpade. "Cartographies of Struggle: Third World Women and the Politics of Feminism. Third World Women and the Politics of Feminism. Edited by

Chandra Talpade Mohanty et al. Indiana: Indiana University Press, 1991.

. Feminism without Borders: Decolonizing Theory, Practicing Solidarity Duke University Press: Durham \& London 2003.

"Under Western Eyes: Feminist Scholarship and Colonial Discourses,"in , Feminism Without Borders: Decolonizing Theory, Practicing Solidarity. Duke University Press: Durham \& London, 2003.

Muller, Ruth Dixon. (1993). "The Sexuality Connection in Reproductive Health." Studies in Family Planning. (vol. 24): 279.

Nakajima, Hiroshi Nakajima. (1997). "Global Health Threats and Foreign Policy." Brown Journal World Affairs. (vol. 4): 320.

Nanorama, Ruth. (January 01, 2005). "Statement by Women's Voice and National Federation of Dalit Women." Under Agenda Item5 (b) on the Rights-Based Approach to the Empowerment of Women, at the ESCAP High Level Meeting for Beijing +5; October 28, 1999." Retrieved from http://www.aworc.org/bpfa/gov/escap/wv_nfdw.html

Northrup, Nancy. (April 02, 2006). "Responding to India Supreme Court Decision on Country's Sterilization Practices." Retrieved from http://www.crlp.org/pr 05 0310india.html

Odim ,Cheryl Johson. "Common Themes, Different Contexts: Third World Women and Feminism," in Third World Women and the Politics of Feminism. Edited by Chandra

Office of the Registrar General, India, "Sample Registration Statistical Report 2002." New Delhi, India: 2004. 
Onyango- Oloka J., and Sylvia Tamale. (1995). "The Personal is Political, "or Why Women's Rights are Indeed Human Rights: An African Perspective on International Feminism" in Human Rights Quarterly (vol. 17.no. 4) :701.

Partha Chatterjee. (1980)."Essay on the Family," by Bhudev Mukopadhy See his "Colonialism, Nationalism and Colonized Women the Contest in India." American Ethnologist :626.

Pateman,Carole. "Feminist Critiques of the Public/Private Dichotomy." Public And Private in Social Life. Stanford: Stanford University Press, 1988.

Programme of Action of the International Conference on Population and Development, Cairo Egypt, Sept. 5-13, 1994, para. 7.12, U.N. Doc. A/CONF.171/13/Rev.1 (1995) [hereinafter ICPD Programme of Action].

Rajasingham,Darini. "On Mediating Multiple Identities: The Shifting Field of Women's Sexualities within the Community, State and Nation," in Margaret A. Schuler, ed., From Basic Needs to Basic Rights: Women's Claim to Human Rights. Washington, DC: Women, Law and Development International Press, 1995.

Ramasundaram, S, T. Rangarajan and S. Muthuramalingam. "The Role of Political Will and Official Commitment in Tamil Nadu's Fertility Decline," Studies of Human Development in India, Discussion Paper Series, No. 24, Trivandrum, India: Centre for Development Research, 1997.

Savan, Marie Angelique. (1982). "Another Development with Women." Development Dialogue, (vol.1. no. 2): 5 .

Seidman, Ann. "Women and the Development of Underdevelopment." In R. Dauber and M. Cains, eds. Women and Technological Change in Developing Countries. Boulder, Colorado: Westview Press. 1981.

Sen, Gita. (April, 07, 2003) "A Comment on India's National Population Policy 2000." Re: cyber-fem:welcome/Sen on India's Population. Policy. May 08 2000." Retrieved from http://www.hsph.harvard.edu/rt21/archives/ 200005/msg00010.html

(Jan/Feb 1995)." The Program of Action: A New Paradigm for population policy." Environment. (vol. 37. no.1),10-15 and 34-7.

"Reproduction: The Feminist Challenge to Social Policy," in Power and Decision: The Social Control of Reproduction.Cambridge: Harvard School of Public Health, 1994. 
Sheppard, Bonnie. (2000). "The Double Discourse on Sexual and Reproductive Rights in Latin America: The Chasm between Public Policy and Private Actions." Health and Human Rights. (vol.4. no.2):113.

Shiva, Vandana. (Spring, 1997). "Economic Globalization, Ecological Feminism, and Sustainable Development."Canadian Woman Studies, (2):22.

Subramanian, N. The History of Tamil Nadu . Madurai, Tamil Nadu: Vaigai Achagam (press), 1972.

Taylor, Allyn L. (1992). "Making the World Health Organization Work: A Legal Framework for Universal Access to the Conditions for Health. American Journal of Law \& Medicine.(18), 301-2.

The University of Maryland. Research Library: Glossary of Scenario Terms. http://www.icons.umd.edu/reslib/display glossary\#T (visited: 02/20/2006)

The World Bank. ( February 29, 2004). Retrieved from http://web.worldbank.org/WBSITE/EXTERNAL/EXTABOUTUS/0,pagePK:439 12 piPK:36602,00.html

The World Bank. ( March 01, 2004) . Retrieved from http://web.worldbank.org/WBSITE/EXTERNAL/EXTABOUTUS/0,pagePK:500 04410 piPK:36602 theSitePK:29708,00.html.

Vajpayee Prime Minister, Atal Behari. (April 30, 2003)."The occasion of India's population crossing the one billion New Delhi May 11, 2000." Retrieved from

Visaria, Leela, Shireen Jejebhoy and Tom Merrick (January, 1999). "From Family Planning to Reproductive Health: Challenges Facing India," in Family Planning Perspectives.( vol. 25), Supplement.

Woodward, David et al. (2001). "Globalization and Health: a Framework for Analysis and Action." Bulleting World Health Organization_(vol. 79. no. 9) : 875-881.

World Bank Report. (February 20, 2004). "The World Bank Group and Population and Reproductive and Child Health in India." Retrieved from http://Inweb18.worldbank.org/sar/sa.nsf/0/0ala904791c49728525687b0062dca8? OpenDocument

Yach Derek, and Douglas Bettcher. (May, 1998). "The Globalization of Public Health, I: Threats and Opportunities." American Journal of Public Health. (vol. 88. no.5): 735-737

Young,Iris. (2003). "Feminist Reactions to the Contemporary Security Regime", Hypatia. (vol. 18. no.1) : 223 


\section{APPENDIX}

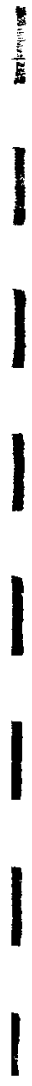

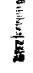

1

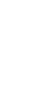

I

Reproduced with permission of the copyright owner. Further reproduction prohibited without permission. 


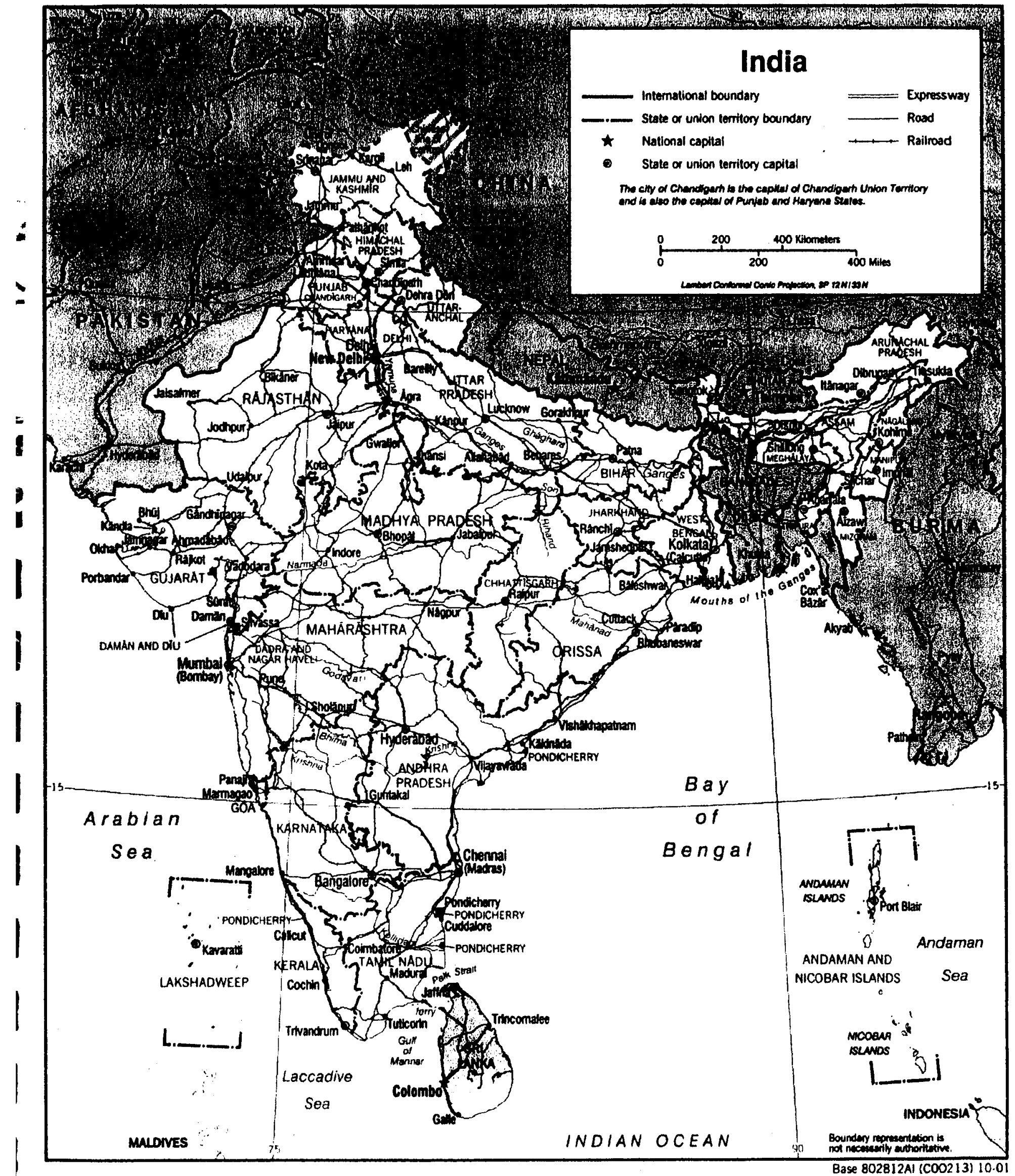




\begin{tabular}{|c|c|c|c|c|c|c|c|c|c|c|}
\hline \multicolumn{11}{|c|}{ 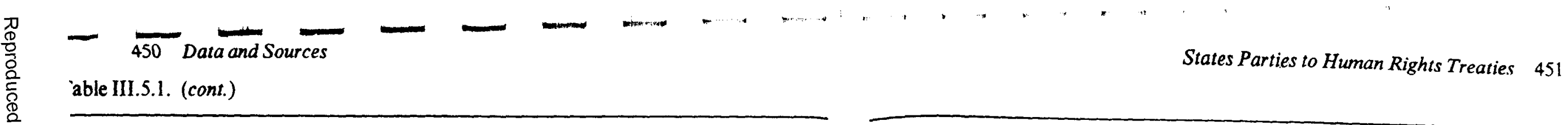 } \\
\hline 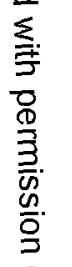 & ate & $\begin{array}{l}\text { Int. Covenant } \\
\text { on Civil and } \\
\text { Political Rights }\end{array}$ & $\begin{array}{l}\text { Optional Protocol } \\
\text { to the Int. Covenant } \\
\text { on Civil and } \\
\text { Political Rights }\end{array}$ & $\begin{array}{l}\text { Int. Covenant } \\
\text { on Economic, } \\
\text { Social and } \\
\text { Cultural Rights }\end{array}$ & $\begin{array}{l}\text { Int. Convention } \\
\text { on the Elimination of } \\
\text { All Forms of Racial } \\
\text { Discrimination }\end{array}$ & $\begin{array}{l}\text { Convention on } \\
\text { the Elimination } \\
\text { of All Forms of } \\
\text { Discrimination } \\
\text { against Women }\end{array}$ & $\begin{array}{l}\text { Optional Protocol } \\
\text { to the Convention } \\
\text { on the Elimination } \\
\text { of All Forms of } \\
\text { Discrimination } \\
\text { against Women }\end{array}$ & $\begin{array}{l}\text { Convention on } \\
\text { the Rights of } \\
\text { the Child }\end{array}$ & $\begin{array}{l}\text { Optional Protocol } \\
\text { to the Convention } \\
\text { on the Rights of } \\
\text { the Child on } \\
\text { Prostitution and } \\
\text { Pornography }\end{array}$ & $\begin{array}{l}\text { Convention } \\
\text { Torture and } \\
\text { Cruel and It } \\
\text { Degrading I } \\
\text { or Punisbme }\end{array}$ \\
\hline$\stackrel{\text { 을 }}{\rightleftharpoons}$ & enada & $x$ & & $x$ & s & $x$ & & $x$ & & \\
\hline $\overrightarrow{\bar{D}}$ & satemala & $x$ & $\mathrm{x}$ & $x$ & $\mathrm{x}$ & $x$ & $\mathbf{s}$ & $\mathrm{x}$ & $\mathrm{s}$ & $x$ \\
\hline 8 & inea & $x$ & $x$ & $x$ & $x$ & $\mathrm{x}$ & & $x$ & & $x$ \\
\hline$\underset{0}{\underline{0}}$ & inea Bissau & s & s & $x$ & s & $x$ & $\mathbf{s}$ & $x$ & $s$ & $s$ \\
\hline 흥 & yana & $x$ & $x$ & $x$ & $x$ & $\mathbf{x}$ & & $x$ & & $x$ \\
\hline$\Xi$ & iti & $x$ & . & & $x$ & $x$ & & $x$ & & \\
\hline$\sum_{\Sigma}^{0}$ & ly See & & & & $x$ & & & $x$ & $x$ & \\
\hline 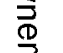 & nduras & $x$ & $s$ & $x$ & 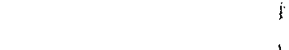 & $x$ & & $x$ & & $x$ \\
\hline 7 & agary & $x$ & . & $x$ & * & $x$ & $x$ & $x$ & 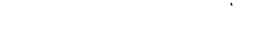 & $x$ \\
\hline$\stackrel{T}{\leftrightarrows}$ & and & $x$ & $x$ & $x$ & $x$ & $x$ & $x$ & $x$ & $x$ & $x$ \\
\hline$\overline{7}$ & ia & $x$ & & $\mathrm{x}$ & $x$ & $x$ & $\cdot$ & $x$ & & $\mathbf{s}$ \\
\hline$\stackrel{\bar{D}}{ᄀ}$ & onesia & & & & $x$ & $x$ & $\mathbf{s}$ & $x$ & s & $x$ \\
\hline$\vec{\Phi}$ & I (Islamic Rep. of) & $x$ & & $x$ & $x$ & & & $x$ & & \\
\hline 응 & 1 & $x$ & . & $x$ & $x$ & $x$ & & $x$ & & \\
\hline$\frac{2}{\bar{n}}$ & and & $x$ & $x$ & $x$ & $x$ & $x$ & $x$ & $x$ & 5 & s \\
\hline$\stackrel{?}{\overline{0}}$ & el & $x$ & & $x$ & $x$ & $x$ & & $x$ & s & $x$ \\
\hline 을 & $i$ & $x$ & $x$ & $\mathrm{x}$ & $x$ & $x$ & $x$ & $x$ & $s$ & $x$ \\
\hline 응 & aica & $x$ & & $x$ & $x$ & $x$ & & $x$ & s & \\
\hline 卷: & $\ln$ & $x$ & & $x$ & $x$ & $x$ & & $x$ & & $x$ \\
\hline$\stackrel{\text { F }}{\vec{\sigma}}$ & an & $x$ & & $x$ & $x$ & $x$ & & $x$ & $\mathbf{s}$ & $x$ \\
\hline$\frac{\pi}{5}$ & akbstan & & & & $x$ & $x$ & $x$ & $x$ & $x$ & $x$ \\
\hline & ra & $x$ & & $x$ & $x$ & $x$ & & $x$ & $s$ & $x$ \\
\hline$\stackrel{\overline{0}}{\risingdotseq}$ & $\begin{array}{l}\text { xati } \\
\text { ait }\end{array}$ & $x$ & & $x$ & $x$ & $x$ & & $\begin{array}{l}x \\
x\end{array}$ & & $x$ \\
\hline$\overparen{\Phi}$ & yszstan & $x$ & $x$ & $x$ & $x$ & $x$ & & $x$ & & $\mathrm{x}$ \\
\hline בె. & People's Dem. Rep. & s & & $s$ & $\mathrm{x}$ & $x$ & & $x$ & & \\
\hline 氙. & a & $x$ & $x$ & $x$ & $x$ & $x$ & & $x$ & & $x$ \\
\hline$\overline{\mathrm{o}}$ & non & $x$ & & $x$ & $x$ & $x$ & & $x$ & s & $\mathrm{x}$ \\
\hline & ho & $x$ & $\mathbf{x}$ & $\mathrm{x}$ & $x$ & $x$ & $\mathbf{s}$ & $x$ & s & $x$ \\
\hline & ia & $s$ & & $\mathbf{s}$ & $x$ & $x$ & & $x$ & & \\
\hline & n Arab Jamahiriya & $x$ & $x$ & $x$ & $x$ & $x$ & & $x$ & & $\mathrm{x}$ \\
\hline & lenstein & $x$ & $x$ & $\mathrm{x}$ & $x$ & $x$ & $x$ & $x$ & s & $x$ \\
\hline & ania & $x$ & $x$ & $x$ & $\mathrm{x}$ & $x$ & $\mathbf{s}$ & $x$ & & $x$ \\
\hline & abourg & $x$ & $x$ & $x$ & $x$ & $x$ & $s$ & $x$ & s & $x$ \\
\hline & gascar & $x$ & $x$ & $\mathbf{x}$ & $x$ & $x$ & s & $x$ & $\mathbf{s}$ & $\mathbf{s}$ \\
\hline & $\dot{n}$ & $x$ & $\mathbf{x}$ & $\mathrm{x}$ & $x$ & $x$ & $s$ & $\mathbf{x}$ & s & $x$ \\
\hline
\end{tabular}




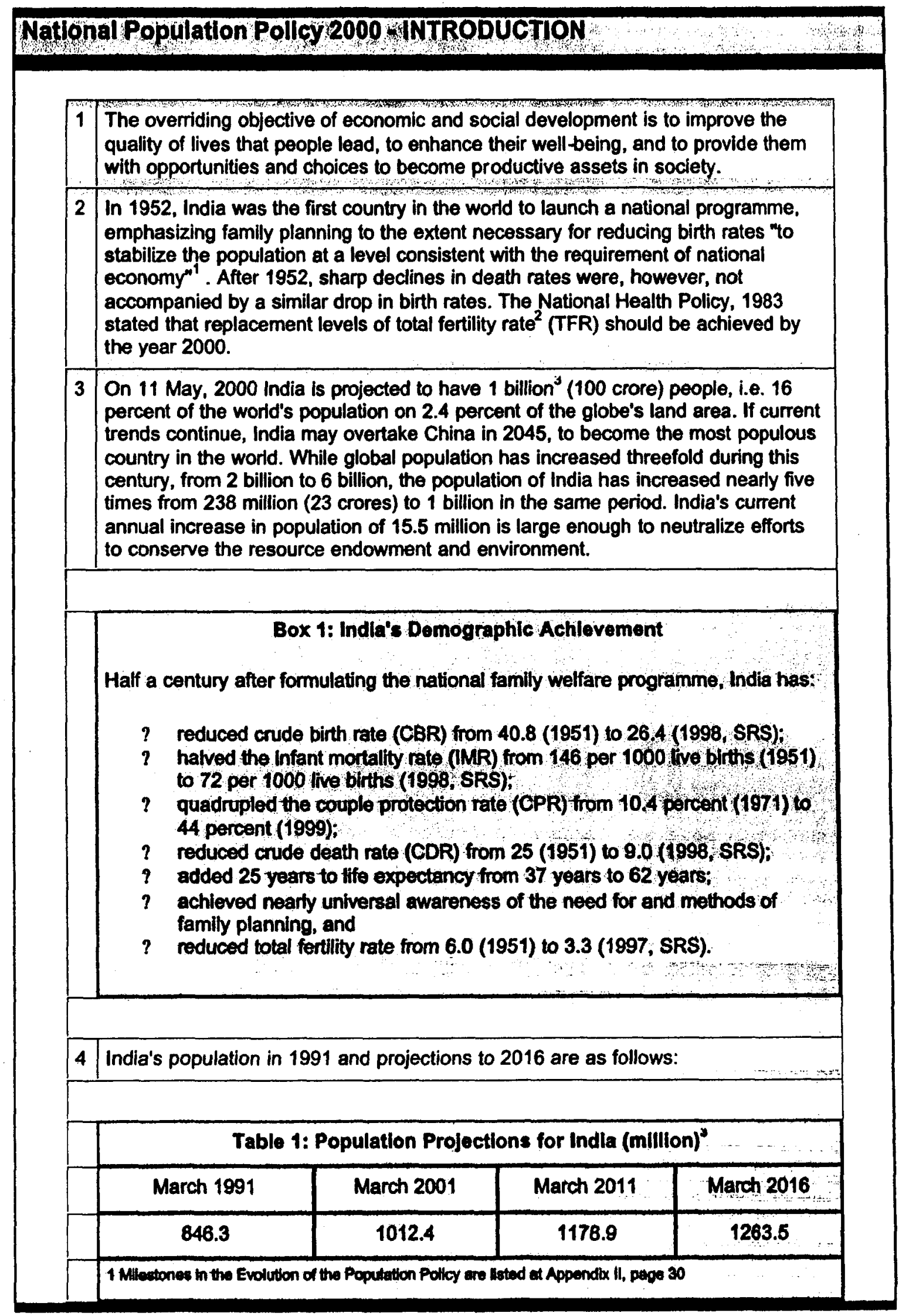




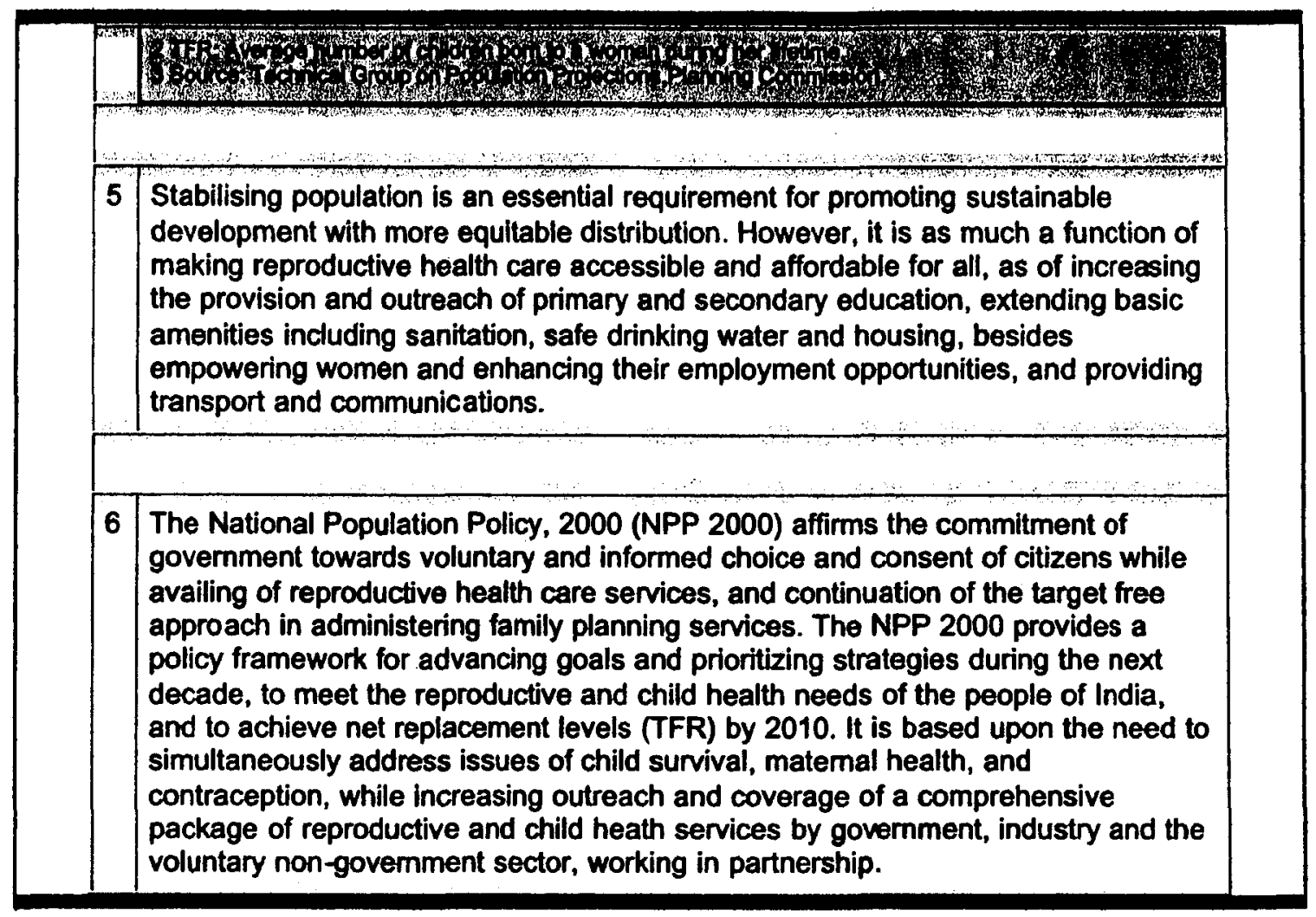

\section{OBJECTIVES}

1 The immediate objective of the NPP 2000 is to address the unmet needs for contraception, health care infrastructure, and health personnel, and to provide integrated service delivery forbasic reproductive and child health care. The medium-term objective is to bring the TFR to replacement levels by 2010 , through vigorous implementation of inter-sectoral operational strategies. The longterm objective is to achieve a stable population by 2045 , at a level consistent with the requirements of sustainable economic growth, social development, and environmental protection.

2 In pursuance of these objectives, the following National Socio-Demographic Goals to be achieved in each case by 2010 are formulated:

\begin{tabular}{|c|c|}
\hline & Box 2: National Socio-Demographlc Goals for 2010 \\
\hline$?$ & $\begin{array}{l}\text { Address the unmet needs for basic reproductive and child heatth } \\
\text { services, supplies and infrastructure. }\end{array}$ \\
\hline$?$ & $\begin{array}{l}\text { Make school education up to age } 14 \text { free and compulsory, and reduce } \\
\text { drop outs at primary and secondary school tevels to below } 20 \text { percent for } \\
\text { both boys and girls. }\end{array}$ \\
\hline$?$ & Reduce infant mortality rate to below 30 per 1000 live births. \\
\hline$?$ & Reduce matemal mortality ratio to below 100 per 100,000 live blrths. \\
\hline$?$ & Achleve universal immunization of children against all vaccine \\
\hline
\end{tabular}




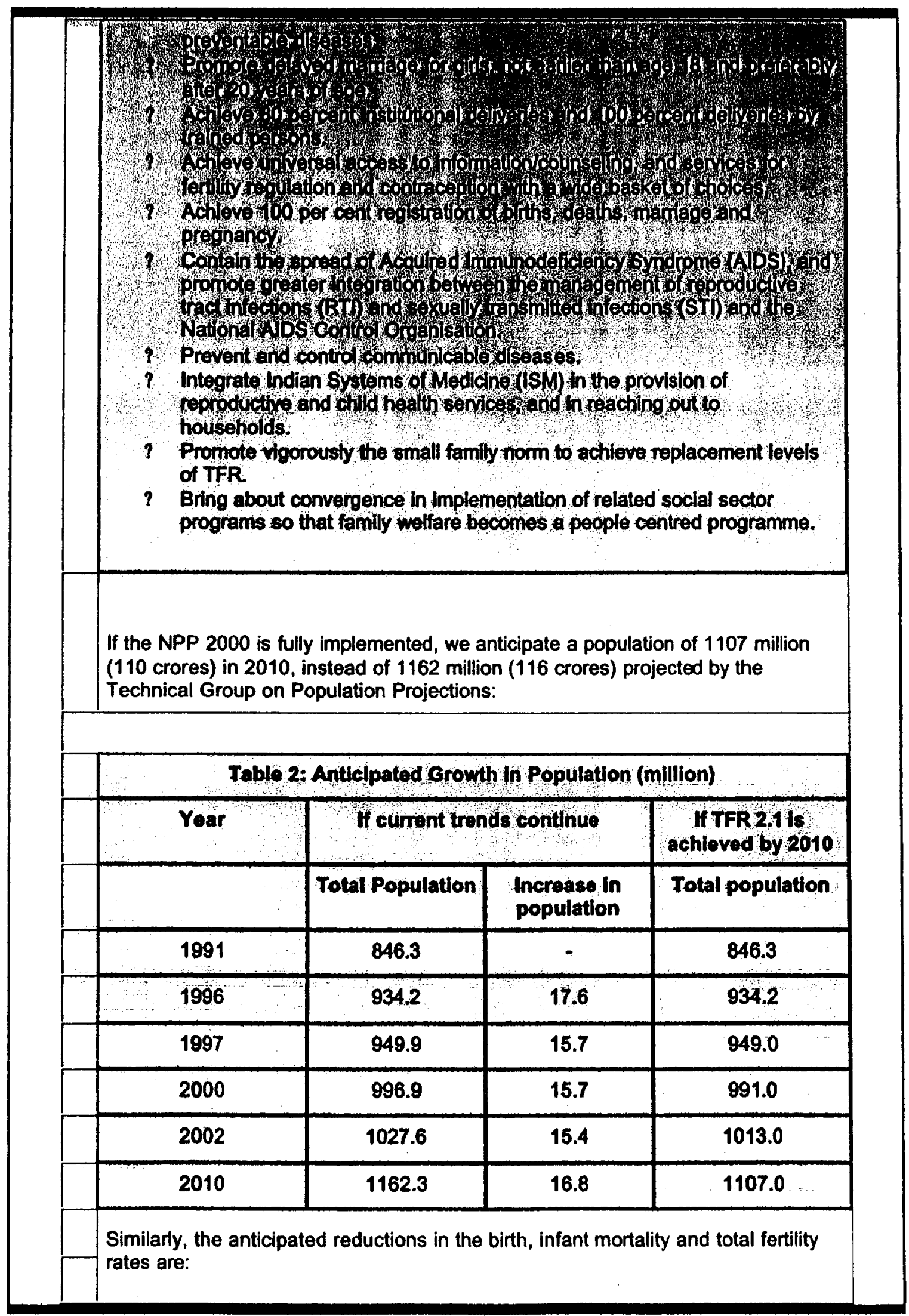




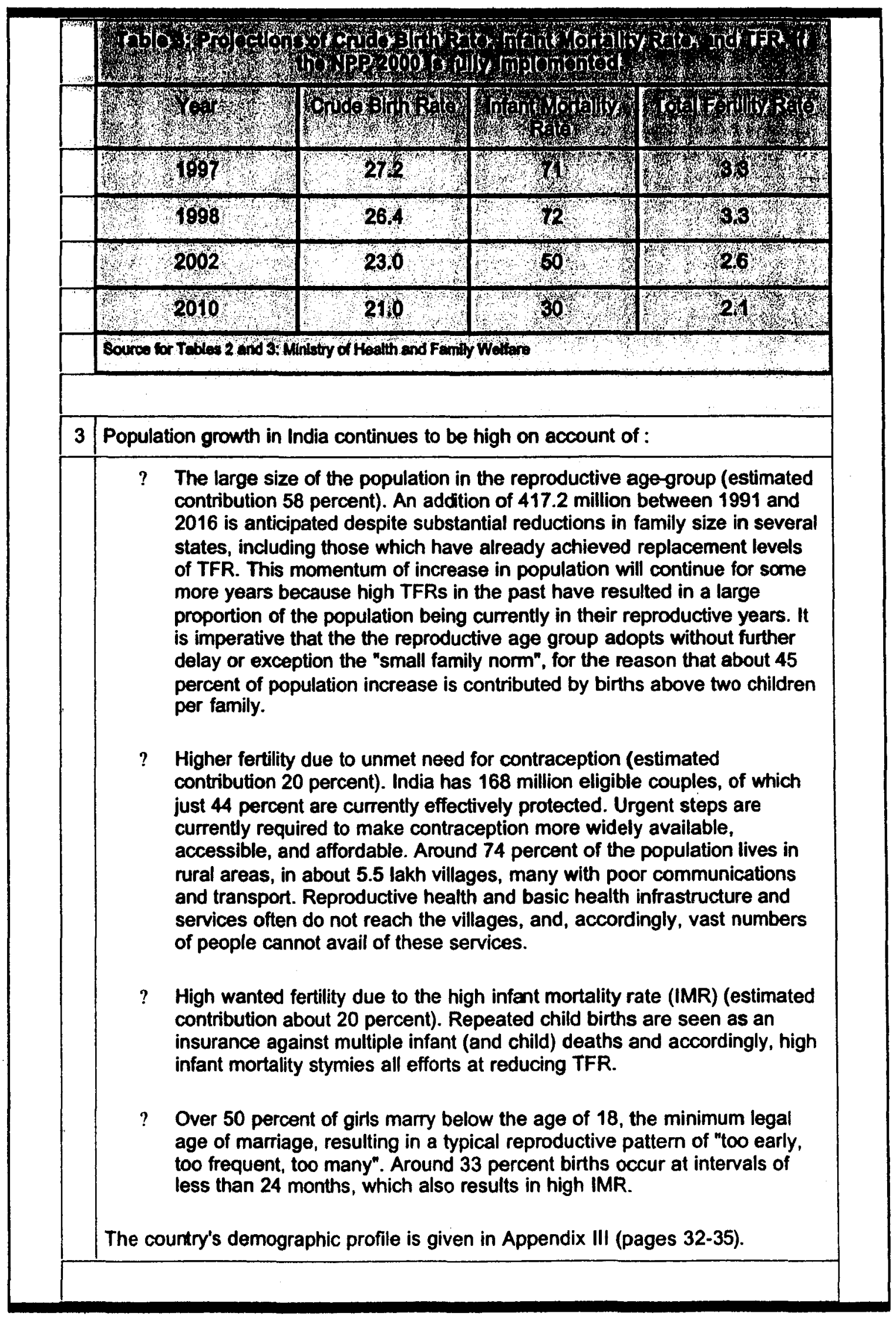


4 Since the management, funding, and implementation of health and education programmes has been decentralised to panchayats, in order to reach household levels, a one-stop, integrated and coordinated service delivery should be provided at village levels, for basic reproductive and child health services. A vast increase in the number of trained birth attendants, at least two per village, is necessary to universalise coverage and outreach of ante-natal, natal and postnatal health care. An equipped maternity hut in each village should be set up to serve as a delivery room, with functioning midwifery kits, basic medication for essential obstetric aid, and indigenous medicines and supplies for maternal and new bom care. A key feature of the integrated service delivery will be the registration at village levels, of births, deaths, marriage, and pregnancies. Each village should maintain a list of community midwives and trained birth attendants, village health guides, panchayat sewa sahayaks, primary school teachers and aanganwadi workers who may be entrusted with various responsibilities in the implementation of integrated service delivery.

4 Source: MOHFW Statistics, 1998.

5 The panchayats should seek the help of community opinion makers to communicate the benefits of smaller, healthier families, the significance of educating girls, and promoting female participation in paid employment. They should also involve civil society in monitoring the availability, accessibility and affordability of services and supplies.

Operational strategies are described in the Action Plan at Appendix I.

(iii) Empowering Women for Improved Health and Nutrition

6 The complex socio-cultural determinants of women's health and nutrition have cumulative effects over a lifetime. Discriminatory childcare leads to malnutrition and impaired physical development of the girl child. Undernutrition and micronutrient deficiency in early adolescence goes beyond mere food entitlements to those nutrition related capabilities that become crucial to a woman's well-being, and through her, to the well-being of children. The positive effects of good health and nutrition on the labour productivity of the poor is well documented. To the extent that women are over-represented among the poor, interventions for improving women's health and nutrition are critical for poverty reduction.

7 Impaired health and nutrition is compounded by early childbearing, and consequent risk of serious pregnancy related complications. Women's risk of premature death and disability is highest during their reproductive years. Malnutrition, frequent pregnancies, unsafe abortions, RTI and STI, all combine to keep the maternal mortality ratio in India among the highest globally.

8 Maternal mortality is not merely a health disadvantage, it is a matter of social injustice. Low social and economic status of girls and women limits their access to education, good nutrition, as well as money to pay for health care and family planning services. The extent of maternal mortality is an indicator of disparity and inequity in access to appropriate health care and nutrition services throughout a lifetime, and particularly during pregnancy and child-birth, and is a crucial factor contributing to high maternal mortality.

9 Programmes for Safe Motherhood, Universal Immunisation, Child Survival and Oral Rehydration have been combined into an Integrated Reproductive and Child 
Health Programme, which also includes promoting management of STIs and RTIs. Women's health and nutrition problems can be largely prevented or mitigated through low cost interventions designed for low income settings.

10 The voluntary non-government sector and the private corporate sector should actively collaborate with the community and government through specific commitments in the areas of basic reproductive and child health care, basic education, and in securing higher levels of participation in the paid work force for women.

Operational strategies are described in the Action Plan at Appendix I.

\section{(iv) Child Health and Survival}

11 Infant mortality is a sensitive indicator of human development. High mortality and morbidity among infants and children below 5 years occurs on account of inadequate care, asphyxia during birth, premature birth, low birth weight, acute respiratory infections, diarthoea, vaccine preventable diseases, malnutrition and deficiencies of nutrients, including Vitamin A. Infant mortality rates have not significantly declined in recent years.

12 Our priority is to intensify neo-natal care. A National Technical Committee should be set up, consisting principally of consultants in obstetrics, pediatrics (neonatologists), family health, medical research and statistics from among academia, public health professionals, clinical practitioners and government. Its terms of reference should include prescribing perinatal audit norms, developing quality improvement activities with monitoring schedules and suggestions for facilitating provision of continuing medical and nursing education to all perinatal health care providers. Implementation at the grass-roots must benefit from current developments in the fields of perinatology and neonatology. The baby friendly hospital initiative (BFHI) should be extended to all hospitals and clinics, up to subcentre levels. Additionally, besides promoting breast-feeding and complementary feeds, the BFHI should include updating of skills of trained birth attendants to improve new bom care practices to reduce the risks of hypothermia and infection. Essential equipment for the new born must be provided at subcentre levels.

13 Child survival interventions i.e. universal immunisation, control of childhood diarthoeas with oral rehydration therapies, management of acute respiratory infections, and massive doses of Vitamin A and food supplements have all helped to reduce infant and child mortality and morbidity. With intensified efforts, the eradication of polio is within reach. However, the decline in standards, outreach and quality of routine immunisation is a matter of concern. Significant improvements need to be made in the quality and coverage of the routine immunisation programme.

Operational strategies are described in the Action Plan at Appendix I.

(v) Meeting the Unmet Needs for Family Welfare Services

14 In both rural and urban areas there continue to be unmet needs for contraceptives, supplies and equipment for integrated service delivery, mobility of health providers and patients, and comprehensive information. It is important to strengthen, energise and make accountable the cutting edge of health infrastructure at the village, subcentre and primary health centre levels, to 
improve facilities for referral transportation, to encourage and strengthen local initiatives for ambulance services at village and block levels, to increase innovative social marketing schemes for affordable products and services and to improve advocacy in locally relevant and acceptable dialects.

Operational strategies are described in the Action Plan in Appendix I.

(vi) Under-Served Population Groups

(a) Urban Slums

15 Nearty 100 million people live in urban slums, with little or no access to potable water, sanitation facilities, and health care services. This contributes to high infant and child mortality, which in turn perpetuate high TFR and maternal mortality. Basic and primary health care, including reproductive and child health care, needs to be provided. Coordination with municipal bodies for water, sanitation and waste disposal must be pursued, and targeted information, education and communication campaigns must spread awareness about the secondary and tertiary facilities available.

Operational strategies are described in the Action Plan in Appendix l.

(b) Tribal Communities, Hill Area Populations and Displaced and Migrant Populations

16 In general, populations in remote and low density areas do not have adequate access to affordable health care services. Tribal populations often have high levels of morbidity arising from poor nutrition, particularly in situations where they are involuntarily displaced or resettled. Frequently, they have low levels of literacy, coupled with high infant, child, and matemal mortality. They remain under-served in the coverage of reproductive and child health services. These communities need special attention in terms of basic health, and reproductive and child health services. The special needs of tribal groups which need to be addressed include the provision of mobile clinics that will be responsive to seasonal variations in the availability of work and income. Information and counseling on infertility, and regular supply of standardised medication will be included.

Operational strategies are described in the Action Plan at Appendix I.

(c) Adolescents

17 Adolescents represent about a fifth of India's population. The needs of adolescents, including protection from unwanted pregnancies and sexually transmitted diseases (STD), have not been specifically addressed in the past. Programmes should encourage delayed marriage and child-bearing, and education of adolescents about the risks of unprotected sex. Reproductive health services for adolescent girls and boys is especially significant in rural India, where adolescent marriage and pregnancy are widely prevalent. Their special requirements comprise information, counseling, population education, and making contraceptive services accessible and affordable, providing food supplements and nutritional services through the ICDS, and enforcing the Child Marriage Restraint Act, 1976. 
Operational strategies are described in the Action Plan in Appendix.

(d) Increased Participation of Men In Planned Parenthood

18 In the past, population programmes have tended to exclude menfolk. Gender inequalities in patriarchal societies ensure that men play a critical role in determining the education and employment of family members, age at marriage, besides access to and utilisation of health, nutrition, and family welfare services for women and children. The active involvement of men is called for in planning families, supporting contraceptive use, helping pregnant women stay healthy, arranging skilled care during delivery, avoiding delays in seeking care, helping after the baby is born and, finally, in being a responsible father. In short, the active cooperation and participation of men is vital for ensuring programme acceptance. Further, currently, over 97 percent of sterilisations are tubectomies and this manifestation of gender imbalance needs to be corrected. The special needs of men include re-popularising vasectomies, in particular noscalpel vasectomy as a safe and simple procedure, and focusing on men in the information and education campaigns to promote the small family norm.

Operational strategies are described in the Action Plan in Appendix I.

\section{(vii) Diverse Health Care Providers}

19 Given the large unmet need for reproductive and child health services, and inadequacies in health care infrastructure it is imperative to increase the numbers and diversify the categories of health care providers. Ways of doing this include accrediting private medical practitioners and assigning them to defined beneficiary groups to provide these services; revival of the system of licensed medical practitioner who, after appropriate certification from the Indian Medical Association (IMA), could provide specified clinical services.

Operational strategies are described in the Action Plan at Appendix !.

(viii) Collaboration With and Commitments from Non-Government Organisations and the Private Sector

20 A national effort to reach out to households cannot be sustained by government alone. We need to put in place a partnership of non-government voluntary organizations, the private corporate sector, government and the community. Triggered by rising incomes and institutional finance, private health care has grown significantly, with an impressive pool of expertise and management skills, and currently accounts for nearly 75 percent of health care expenditures.

However, despite their obvious potential, mobilising the private (profit and nonprofit) sector to serve public health goals raises governance issues of contracting, accreditation, regulation, referral, besides the appropriate division of labour between the public and private health providers, all of which need to be addressed carefully. Where government interventions or capacities are insufficient, and the participation of the private sector unviable, focused service delivery by NGOs may effectively complement government efforts.

Operational strategies are described in the Action Plan in Appendix I.

(ix) Mainstreaming Indian Systems of Medicine and Homeopathy 
21 India's community supported ancient but living traditions of indigenous systems of medicine has sustained the population for centuries, with effective cures and remedies for numerous conditions, including those relating to women and children, with minimal side effects. Utilisation of ISMH in basic reproductive and chlld health care will expand the pool of effective health care providers, optimise utilisation of locally based remedies and cures, and promote lowcost health care. Guidelines need to be evolved to regulate and ensure standardisation, efficacy and safety of ISMH drugs for wider entry into national markets.

22 Particular challenges include providing appropriate training, and raising awareness and skill development in reproductive and child health care to the institutionally qualified ISMH medical practitioners. The easibility of utilising their services to fill in gaps in manpower at village levels, and at subcentres and primary health centres may be explored. ISMH institutions, hospitals and dispensaries may be utilised for reproductive and child health care programmes. At village levels, the services of the ISMH "barefoot doctors", after appropriate training, may be utilised for advocacy and counseling, for distributing supplies and equipment, and as depot holders. ISMH practices may be applied at village maternity huts, and at household levels, for antenatal, natal and post natal care, and for nurture of the new born.

Operational strategies are described in the Action Plan in Appendix I.

(x) Contraceptive Technology and Research on Reproductive and Child Health

23 Government must constantly advance, encourage, and support medical, social science, demographic and behavioural science research on maternal, child and reproductive health care issues. This will improve medical techniques relevant to the country's needs, and strengthen programme and project design and implementation. Consultation and frequent dialogue by Government with the existing network of academic and research institutions in allopathy and ISMH, and with other relevant public and private research institutions engaged in social science, demography and behavioural research must continue. The International Institute of Population Sciences, and the population research centres which have been set up to pursue applied research in population related matters, need to be revitalised and strengthened.

24 Applied research relies upon constant monitoring of performance at the programme and project levels. The National Health and Family Welfare Survey provides data on key health and family welfare indicators every five years. Data from the first National Family Health Survey (NFHS-1), 1992-93, has been updated by NFHS-2, 1998-99, to be published shortly. Annual data is generated by the Sample Registration Survey, which, inter alia, maps at state levels the birth, death and infant mortality rates. Absence of regular feedback has been a weakness in the family welfare progamme. For this reason, the Department of Family Welfare is strengthening its management information systems (MIS) and has commenced during 1998, a system of ascertaining impacts and outcomes through district surveys and facility surveys. The district surveys cover $50 \%$ districts every year, so that every 2 years there is an update on every district in the country. The facility surveys ascertain the availability of infrastructure and services up to primary health centre level, covering one district per month. The feedback from both these surveys enable remedial action at district and sub- 


\begin{tabular}{|c|c|}
\hline & $\begin{array}{l}\text { district levels. } \\
\text { Operational strategies are described in the Action Plan in Appendix I. } \\
\text { (xi) Providing for the Older Population }\end{array}$ \\
\hline 25 & $\begin{array}{l}\text { Improved life expectancy is leading to an increase in the absolute number and } \\
\text { proportion of persons aged } 60 \text { years and above, and is anticipated to nearly } \\
\text { double during } 1996-2016 \text {, from } 62.3 \text { million to } 112.9 \text { million } 5 \text {. When viewed in } \\
\text { the context of significant weakening of traditional support systems, the elderly } \\
\text { are increasingly vulnerable, needing protection and care. Promoting old age } \\
\text { health care and support will, over time, also serve to reduce the incentive to have } \\
\text { large families. }\end{array}$ \\
\hline 26 & $\begin{array}{l}\text { The Ministry of Social Justice and Empowerment has adopted in January } 1999 \text { a } \\
\text { National Policy on Older Persons. It has become important to build in geriatric } \\
\text { health concerns in the population policy. Ways of doing this include sensitising, } \\
\text { training and equipping rural and urban health centres and hospitals for providing } \\
\text { geriatric health care; encouraging NGOs to design and implement formal and } \\
\text { informal schemes that make the elderly economically selfreliant; providing for } \\
\text { and routinising screening for cancer, osteoporosis, and cardiovascular conditions } \\
\text { in primary health centres, community health centres, and urban health care } \\
\text { centres at primary, secondary and tertiary levels; and exploring tax incentives to } \\
\text { encourage grown-up children to look after their aged parents. } \\
\text { Operational strategies are described in the Action Plan in Appendix I. } \\
\text { (xii) Information, Education, and Communication }\end{array}$ \\
\hline 27 & $\begin{array}{l}\text { Information, education and communication (IEC) of family welfare messages } \\
\text { must be clear, focused and disseminated everywhere, including the remote } \\
\text { comers of the country, and in local dialects. This will ensure that the messages } \\
\text { are effectively conveyed. These need to be strengthened and their outreach } \\
\text { widened, with locally relevant, and locally comprehensible media and messages. } \\
\text { On the model of the total literacy campaigns which have successfully mobilised } \\
\text { local populations, there is need to undertake a massive national campaign on } \\
\text { population related issues, via artists, popular film stars, doctors, vaidyas, hakims, } \\
\text { nurses, local midwives, women's organizations, and youth organizations. } \\
\text { Operational strategies are described in the Action Plan in Appendix I. }\end{array}$ \\
\hline
\end{tabular}

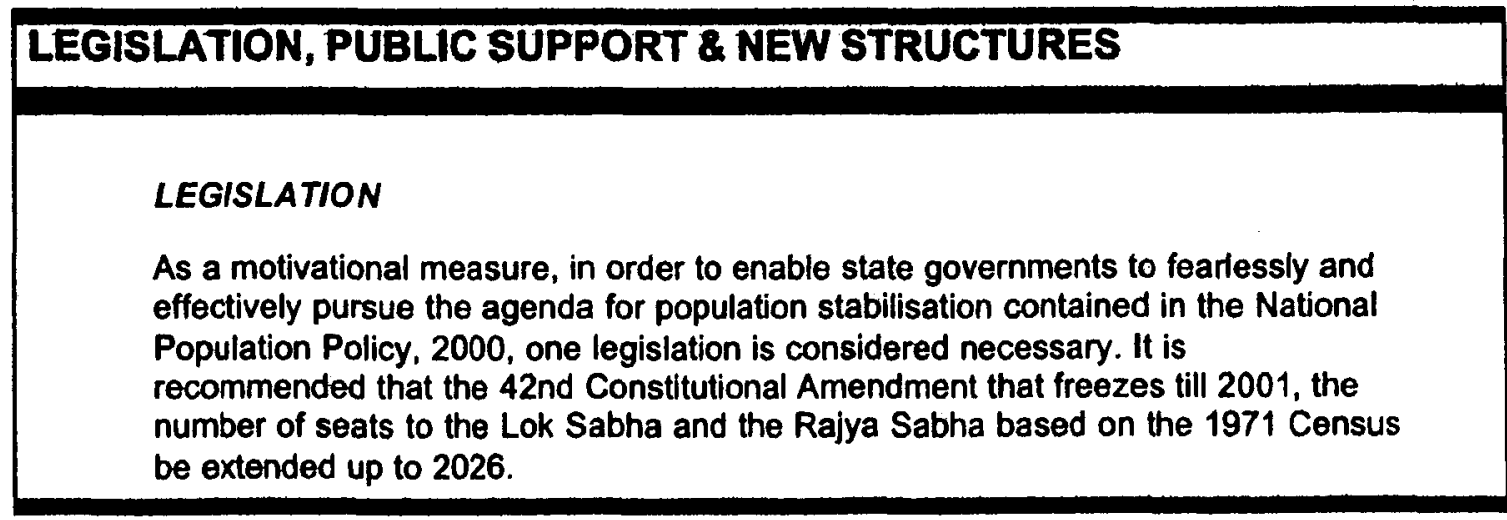




\section{PUBLIC SUPPORT}

Demonstration of strong support to the small family norm, as well as personal example, by political, community, business, professional and religious leaders, media and film stars, sports personalities, and opinion makers, will enhance its acceptance throughout society. The government will actively enlist their support in concrete ways.

\section{NEW STRUCTURES}

The NPP 2000 is to be largely implemented and managed at panchayat and nagar palika levels, in coordination with the concerned state/Union Territory administrations. Accordingly, the specific situation in each state/UT must be kept in mind. This will require comprehensive and multisectoral coordination of planning and implementation between health and family welfare on the one hand, along with schemes for education, nutrition, women and child development, safe drinking water, sanitation, rural roads, communications, transportation, housing, forestry development, environmental protection, and urban development. Accordingly, the following structures are recommended:

\section{(I) National Commission on Population}

A National Commission on Population, presided over by the Prime Minister, will have the Chief Ministers of all states and UTs, and the Central Minister in charge of the Department of Family Welfare and other concerned Central Ministries and Departments, for example Department of Woman and Child Development, Department of Education, Department of Social Justice and Empowerment in the Ministry of HRD, Ministry of Rural Development, Ministry of Environment and Forest, and others as necessary, and reputed demographers, public health professionals, and NGOs as members. This Commission will oversee and review implementation of policy. The Commission Secretariat will be provided by the Department of Family Welfare.

\section{(ii) State I UT Commissions on Population}

Each state and UT may consider having a State / UT Commission on Population, presided over by the Chief Minister, on the analogy of the National Commission, to likewise overseo and review implementation of the NPP 2000 in the state / UT.

\section{(iii) Coordination Cell in the Planning Commission}

The Planning Commission will have a Coordination Cell for inter-sectoral coordination between Ministries for enhancing performance, particularly in States/UTs needing special attention on account of adverse demographic and human development indicators.

\section{(iv) Technology Mission in the Department of Family Welfare}

To enhance performance, particularly in states with currently below average sociodemographic indices that need focused attention, a Technology Mission in the Department of Family Welfare will be established to provide technology support in respect of design and monitoring of projects and programmes for reproductive and child health, as well as for IEC campaigns. 


\section{LEGISLATION}

As a motlvational measure, in order to enable state governments to fearlessly and effectively pursue the agenda for population stabilisation contained in the National Population Policy, 2000, one legislation is considered necessary. It is recommended that the 42nd Constitutional Amendment that freezes till 2001, the number of seats to the Lok Sabha and the Rajya Sabha based on the 1971 Census be extended up to 2026.

\section{PUBLIC SUPPORT}

Demonstration of strong support to the small family norm, as well as personal example, by political, community, business, professional and religious leaders, media and film stars, sports personalities, and opinion makers, will enhance its acceptance throughout society. The government will actively enlist their support in concrete ways.

\section{NEW STRUCTURES}

The NPP 2000 is to be largely implemented and managed at panchayat and nagar palika levels, in coordination with the concerned state/Union Territory administrations. Accordingly, the specific situation in each state/UT must be kept in mind. This will require comprehensive and multisectoral coordination of planning and implementation between health and family welfare on the one hand, along with schemes for education, nutrition, women and child development, safe drinking water, sanitation, rural roads, communications, transportation, housing, forestry development, environmental protection, and urban development. Accordingly, the following structures are recommended:

\section{(i) National Commission on Population}

A National Commission on Population, presided over by the Prime Minister, will have the Chief Ministers of all states and UTs, and the Central Minister in charge of the Department of Family Welfare and other concerned Central Ministries and Departments, for example Department of Woman and Child Development, Department of Education, Department of Social Justice and Empowerment in the Ministry of HRD, Ministry of Rural Development, Ministry of Environment and Forest, and others as necessary, and reputed demographers, public health professionals, and NGOs as members. This Commission will oversee and review implementation of policy. The Commission Secretariat will be provided by the Department of Family Welfare.

\section{(ii) State I UT Commisslons on Population}

Each state and UT may consider having a State / UT Commission on Population, presided over by the Chief Minister, on the analogy of the National Commission, to likewise oversee and review implementation of the NPP 2000 in the state / UT.

\section{(iii) Coordination Cell in the Planning Commission}

The Planning Commission will have a Coordination Cell for inter-sectoral coordination between Ministries for enhancing performance, particularly in States/UTs needing special attention on account of adverse demographic and human development indicators.

(iv) Technology Mission In the Department of Family Welfare 
To enhance performance, particularly in states with currently below average sociodemographic indices that need focused attention, a Technology Mission in the Department of Family Welfare will be established to provide technology support in respect of design and monitoring of projects and programmes for reproductive and child health, as well as for IEC campaigns.

\title{
FUNDING, PROMOTIONAL AND MOTIVATIONAL MEASURES FOR ADOPTION OF THE SMALL FAMILY NORM
}

\begin{abstract}
FUNDING
The programmes, projects and schemes premised on the goals and objectives of the NPP 2000 , and indeed all efforts at population stabilisation, will be adequately funded in view of their critical importance to national development. Preventive and promotive services such as antenatal and post-natal care for women, immunisation for children, and contraception will continue to be subsidised for all those who need the services. Priority in allocation of funds will be given to improving health care infrastructure at the community and primary health centres, subcentre and village levels. Critical gaps in manpower will be remedied through redeployment, particularly in under-served and inaccessible areas, and referral linkages will be improved. In order to implement immediately the Action Plan, it would be necessary to double the annual budget of the Department of Family Welfare to enable govemment to address the shortfall in unmet needs for health care infrastructure, services and supplies (in Appendix IV).

Even though the annual budget for population stabilisation activities assigned to the Department of Family Welfare has increased over the years, at least 50 percent of the budgetary outlay is deployed towards non-plan activities (recurring expenditures for maintenance of health care infrastructure in the states and UTs, and towards salaries). To illustrate, of the annual budget of Rs. 2920 crores for 1999-2000, nearly Rs 1500 crores is allocated towards non-plan activities. Only the remaining 50 percent becomes available for genuine plan activities, inciuding procurement of supplies and equipment. For these reasons, since 1980 the Department of Family Welfare has been unable to revise norms of operational costs of health infrastructure, which in tum has impacted directly the quality of care and outreach of services provided.
\end{abstract}

PROMOTIONAL AND MOTIVATIONAL MEASURES FOR ADOPTION OF THE SMALL FAMILY NORM

The following promotional and motivational measures will be undertaken:

(i) Panchayats and Zila Parishads will be rewarded and honoured for exemplary performance in universalising the small family norm, achieving reductions in infant mortality and birth rates, and promoting literacy with completion of primary schooling.

(ii) The Balika Samridhi Yojana run by the Department of Women and Child Development, to promote survival and care of the girl child, will continue. A cash incentive of Rs. 500 is awarded at the birth of the girl child of birth order 1 or 2. 
(iii) Maternity Benefit Scheme run by the Department of Rural Development will continue. A cash incentive of Rs. 500 is awarded to mothers who have their first child after 19 years of age, for birth of the first or second child only. Disbursement of the cash award will in future be linked to compliance with ante-natal check up, institutional delivery by trained birth attendant, registration of birth and BCG immunisation.

(Iv) A Family Welfare-tinked Health Insurance Plan will be established. Couples below the poverty line, who undergo sterilisation with not more than two living children, would become eligible (along with children) for health insurance (for hospitalisation) not exceeding Rs. 5000, and a personal accident insurance cover for the spouse undergoing sterilisation.

(v) Couples below the poverty line, who marry after the legal age of marriage, register the marriage, have their first child after the mother reaches the age of 21 , accept the small family norm, and adopt a terminal method after the birth of the second child, will be rewarded.

(vi) A revolving fund will be set up for income-generating activities by villagelevel self help groups, who provide community-level health care services.

(vii) Crèches and child care centres will be opened in rural areas and urban slums. This will facilitate and promote participation of women in paid employment.

(viii) A wider, affordable choice of contraceptives will be made accessible at diverse delivery points, with counseling services to enable acceptors to exercise voluntary and informed consent.

(ix) Facilities for safe abortion will be strengthened and expanded.

(x) Products and services will be made affordable through innovative social marketing schemes.

(xi) Local entrepreneurs at village levels will be provided soft loans and encouraged to run ambulance services to supplement the existing arrangements for referral transportation.

(xii) Increased vocational training schemes for girls, leading to selfemployment will be encouraged.

(xii) Strict enforcement of Child Marriage Restraint Act, 1976.

(xiv) Strict enforcement of the Pre-Natal Diagnostic Techniques Act, 1994.

(xv) Soft loans to ensure mobility of the ANMs will be increased.

(xvi) The 42nd Constitutional Amendment has frozen the number of representatives in the Lok Sabha (on the basis of population) at 1971 Census levels. The freeze is currently valid until 2001, and has served as an incentive for State Governments to fearlessly pursue the agenda for population stabilisation. This freeze needs to be extended until 2026. 


\section{CONCLUSION}

In the new millenium, nations are judged by the well-being of their peoples; by levels of health, nutrition and education; by the civil and political liberties enjoyed by their citizens; by the protection guaranteed to children and by provisions made for the vulnerable and the disadvantaged.

The vast numbers of the people of India can be its greatest asset if they are provided with the means to lead healthy and economically productive lives. Population stabilisation is a multisectoral endeavour requiring constant and effective dialogue among a diversity of stakeholders, and coordination at all levels of the government and society. Spread of literacy and education, increasing availability of affordable reproductive and child health services, convergence of service delivery at village levels, participation of women in the paid work force, together with a steady, equitable improvement in family incomes, will facilitate early achievement of the socio-demographic goals. Success will be achieved if the Action Plan contained in the NPP 2000 is pursued as a national movement. 